Portland State University

PDXScholar

Spring 3-26-2012

\title{
The Role of Habitat Restoration and Conservation in the Changing Socio-economic Conditions of Grant County, Oregon
}

Kristen Lauren Senkyr

Portland State University

Follow this and additional works at: https://pdxscholar.library.pdx.edu/open_access_etds

Part of the Environmental Monitoring Commons, Natural Resources and Conservation Commons, and the Sustainability Commons

Let us know how access to this document benefits you.

\section{Recommended Citation}

Senkyr, Kristen Lauren, "The Role of Habitat Restoration and Conservation in the Changing Socioeconomic Conditions of Grant County, Oregon" (2012). Dissertations and Theses. Paper 463. https://doi.org/10.15760/etd.463

This Thesis is brought to you for free and open access. It has been accepted for inclusion in Dissertations and Theses by an authorized administrator of PDXScholar. Please contact us if we can make this document more accessible: pdxscholar@pdx.edu. 
The Role of Habitat Restoration and Conservation in the Changing Socio-economic Conditions of Grant County, Oregon

by

K. Lauren Senkyr

A thesis submitted in partial fulfillment of the requirements for the degree of

\author{
Master of Science \\ in \\ Environmental Science and Management
}

Thesis Committee:

Joseph Maser, Chair

Richard Dewey

David Ervin

Michael Hibbard

Portland State University

2012 


\begin{abstract}
Habitat restoration has socio-economic as well as biophysical impacts. In Grant County, Oregon a recent influx of funding and technical resources for habitat restoration has led to focused monitoring efforts there to better understand the impacts. This study explores how local land use and land management practices are changing in Grant County as a result of restoration and other drivers. In-depth interviews were conducted with 17 landowners, land managers, and long time residents to document the change they have observed and identify how they are adapting. The results suggest that many interconnected social, economic, and ecological changes have taken place in Grant County in the recent past, of which the increased focus on restoration and conservation is just one. Other significant changes include the decline of the timber industry, shifting land ownership patterns, intensified regulation of natural resources, and increased environmental awareness. Ways that the community is adapting and additional ways in which they might more successfully adapt to these changes were identified. Recommendations for how to contribute to a more resilient Grant County are presented for the regulatory, academic, and scientific communities.
\end{abstract}




\section{Acknowledgments}

This thesis would literally not have been possible without the candid stories and keen insights of the Grant County residents who agreed to be interviewed. It was an honor to be accepted into their homes, shown around such a beautiful landscape, and be treated to so many hours of discourse. Whether sitting around a kitchen table, under a tree, or in a pick-up truck, the participants in this research exhibited a generosity of time and spirit from which I have learned a great deal. Special thanks to Judge Webb for his philosophical perspective and the many introductions.

I am grateful to my committee members for their encouragement, guidance, and patience. Thanks to Joe Maser for pushing me to do a formal thesis and take on this experiment in socio-ecological research. Thanks to Dick Dewey for his introduction to the ESM Department and to the Miller Foundation-funded research assistantship that led me to my research topic. Thanks to Mike Hibbard for linking me into the socioeconomic monitoring project with the IMW, as well as for many brainstorms and crash courses in sociology. Many thanks to Dave Ervin for his pertinent classes and support of interdisciplinary research.

I would like to express sincere thanks to I.M. Systems Group, my employer, for their financial support of my education at Portland State University. Working for IMSG at NOAA's Restoration Center I was granted a level of flexibility and encouragement in the workplace that I am confident could not be found elsewhere. I am particularly grateful to my colleagues, Megan Callahan Grant and Megan Hilgart, for their help 
balancing my work load, accommodating my class schedule, and making the office a nice place to be.

Lastly I would like to express my gratitude to the friends and family who kept me sane during the 3 years that it took me to complete my masters degree while working full time. I know it hasn't been easy. I could not have done it without the many long distance phone calls, cups of tea, and late night chats. 


\section{Table of Contents}

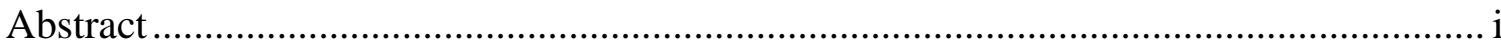

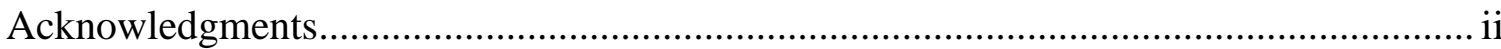

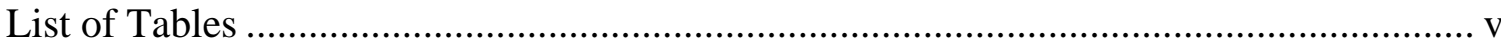

List of Figures ................................................................................................... vi

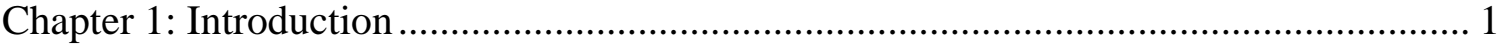

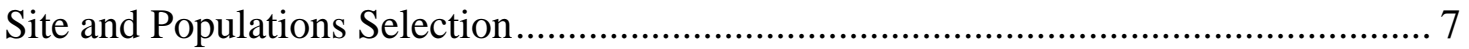

Chapter 2: Literature Review ...................................................................................... 11

Monitoring the Socio-economic Impacts of Habitat Restoration ............................. 11

Community-based Natural Resource Management ................................................ 13

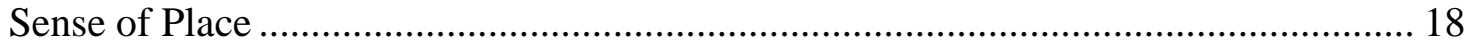

Resilience of Social-Ecological Systems ............................................................. 21

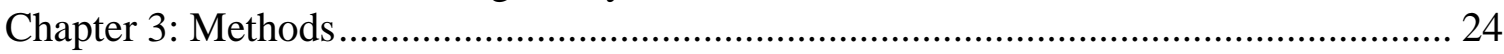

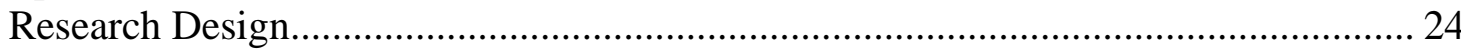

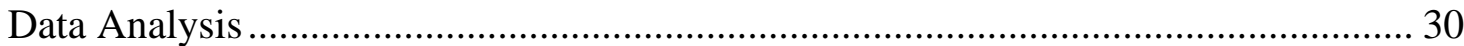

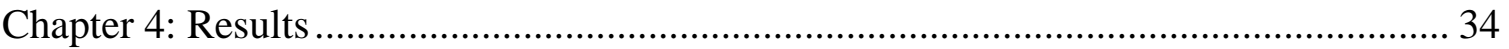

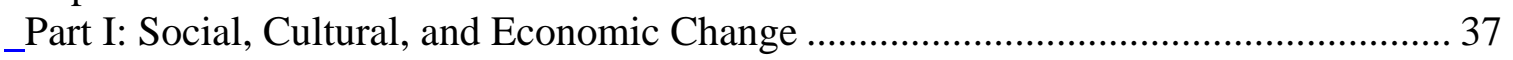

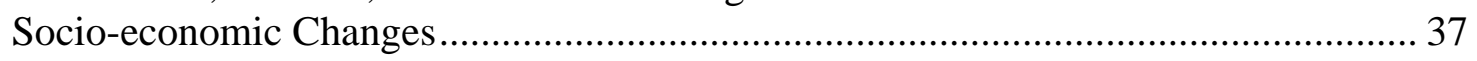

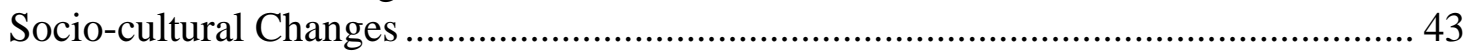

Part II: Socio-Ecological Change: Land Use and Land Management Then and Now ... 49

Land Management Practices of the Past ................................................................ 49

Change in Condition of the Resource ................................................................... 54

Current Land Management and Land Use Practices............................................... 56

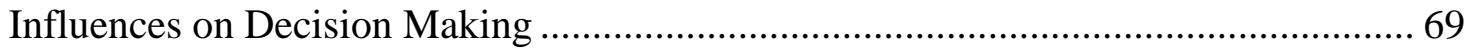

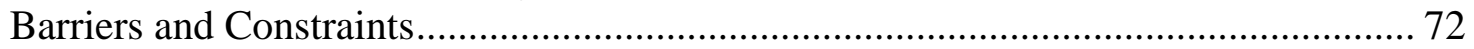

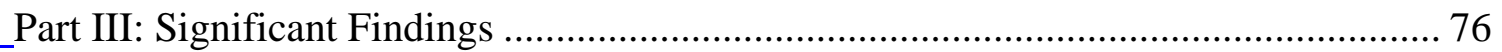

A Common Desire for Balance- "There's no middle ground." ................................. 76

Sustainability- "Sustainability is not even a topic that's brought up today." .............. 78

Preservation versus Conservation- "Anything that has life, you can't preserve it." .... 79

Single Species Focus- "You've got to keep the whole picture in front of you."........... 80

Ranchers as Stewards- "We're the ones that are managing for a hundred years. "..... 81

Common Ground- "That's what Grant County has, the beautiful open space." ......... 83

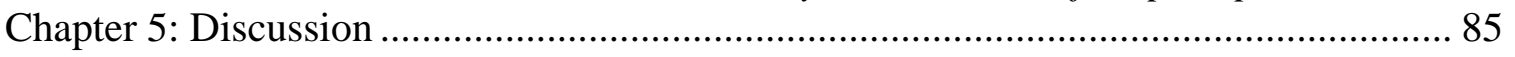

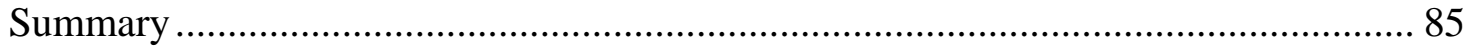

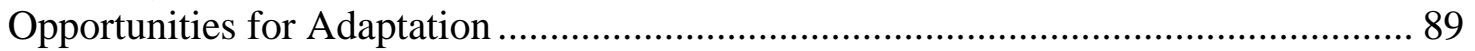

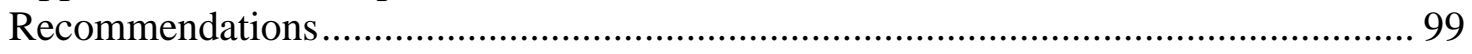

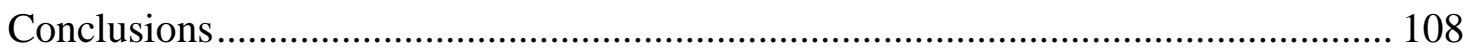

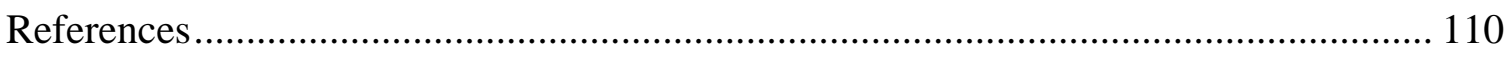

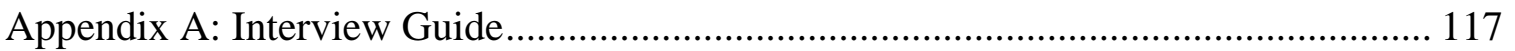

Appendix B. Informed Consent Form ................................................................... 118

Appendix C. Human Subjects Approval.................................................................... 119

Appendix D. Human Subjects Extension Approval ................................................... 120

Appendix E. Quantification of Interview Responses................................................. 121 


\section{List of Tables}

Table 1: Socio-economic metrics being monitored in the Middle Fork Intensively Monitored Watershed in Grant County, Oregon.....................................4

Table 2: Population Change in Oregon Counties, 2000 to 2009..........................10

Table 3: Basic Characteristics of the 17 Individuals Interviewed for this Study..........28

Table 4: Example Coding Categories.............................................30

Table 5: Summary of the Most Frequently Described Changes in Land Use and Land Management in Grant County..................................................

Table 6: Main Influences on Decision Making Described in the Interviews............69

Table 7: Summary of Significant Findings..................................... 76

Table 8: Columbia Basin Water Transactions Program Agreements in the Middle

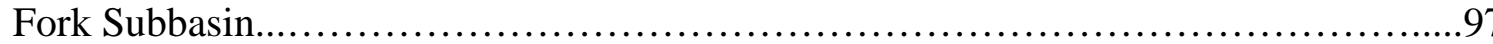




\section{List of Figures}

Figure 1: Map of the John Day River Basin, Middle Fork John Day River Subbasin, and Grant County, Oregon.......................................................

Figure 2: A Concept Map Depicting the Main Research Questions of this Study..........5

Figure 3: Number of Restoration Projects Implemented in the Middle Fork Subbasin, 1995-2009.

Figure 4: Investments (both Cash and Inkind) in Restoration Projects in the Middle Fork Subbasin, 1995-2009........................................................

Figure 5: Example of a Matrix Developed for Qualitative Data Analysis...............32

Figure 6: Concept Map Diagramming Some of the Most Significant Social, Economic, and Ecological Changes Affecting Land Use and Land Management in Grant County..............................................................36

Figure 7: Grant County Travel-Generated Expenditures from Hunting, Fishing, and Wildlife Viewing in 2008. 


\section{Chapter 1: Introduction}

The management of our natural resources is influenced by a variety of environmental, economic, social, and personal considerations. These considerations are often competing, conflicting, and changing through time as ecological and economic conditions, culture, and values change. These issues are particularly significant and controversial in heavily resource-dependent, rural communities where people's livelihoods are strongly connected to the land (Kelly and Bliss 2009; Hunter et. al. 2005). This study uses in-depth interviews to examine the social, ecological and economic factors that are influencing land use and land management changes in one such community.

Grant County, Oregon is an example of a highly resource-dependent community. The local economy has historically been based on mining, timber, and agricultural production (Columbia-Blue Mountain Resource Conservation and Development Area 2005). As the viability of these industries has declined, significant social, political, and economic resources have been allocated towards environmental causes such as conservation, preservation, and restoration (Grant 1993; Bureau of Reclamation 2008). The John Day River flows through Grant County (see Figure 1) and is believed by natural resource managers to be one of the Columbia Basin's most promising opportunities for recovering nearly extinct fish populations that are currently listed under the Endangered Species Act (Columbia-Blue Mountain Resource Conservation and Development Area 2005). Salmon and steelhead habitat restoration is one of the primary management 


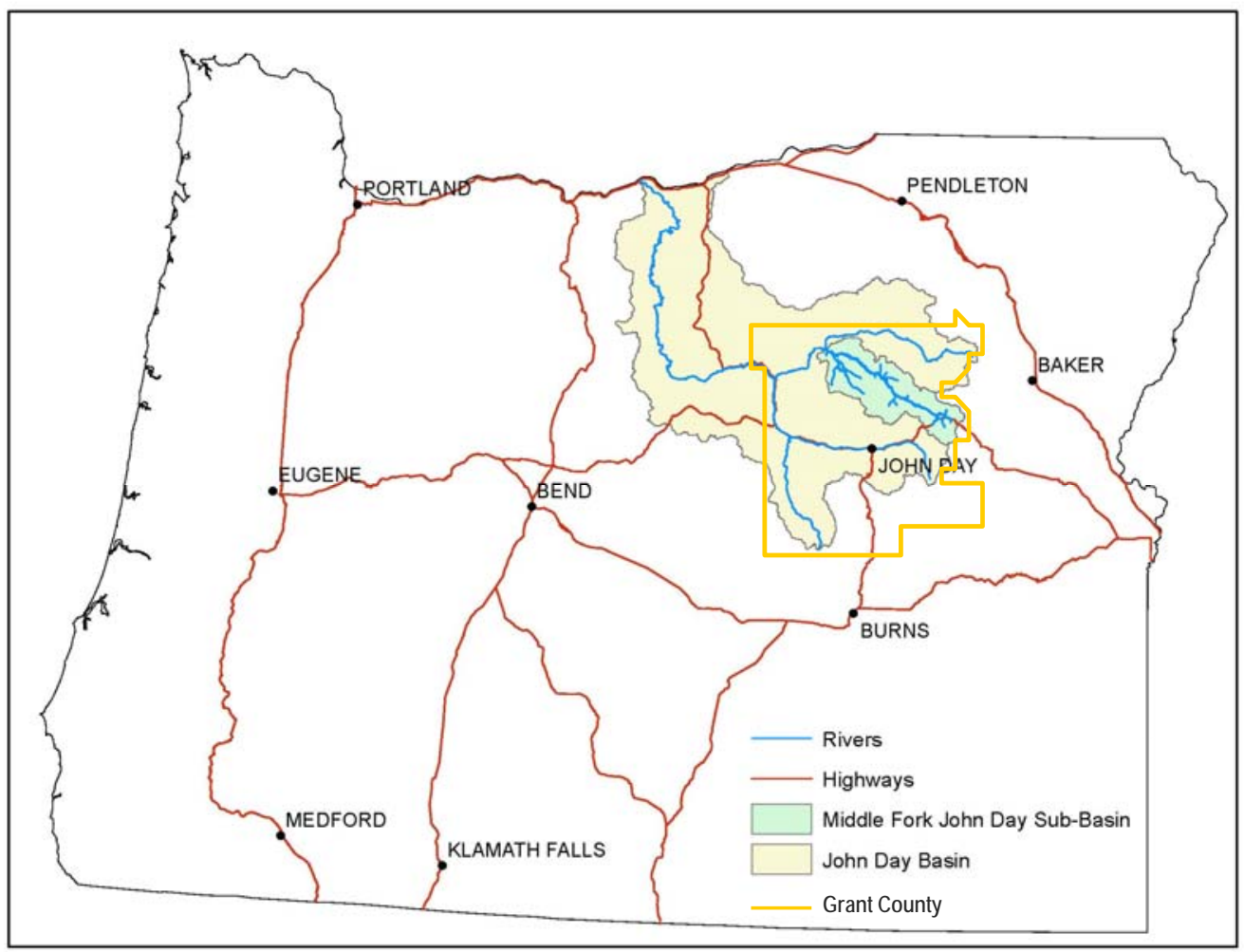

Figure 1: Map of the John Day River Basin, Middle Fork John Day River Subbasin, and Grant County, Oregon.

techniques being used to achieve this goal in the John Day, receiving millions of dollars of funding annually (OWEB 2011).

There is currently a strong push for focused monitoring of the effects of restoration projects to ensure the outcomes of restoration are well understood in this interdisciplinary field (Roni 2005; Kershner 1997). In 2008, the Upper Middle Fork of the John Day River was designated an Intensively Monitored Watershed (IMW) by the National Oceanic and Atmospheric Administration (NOAA)’s Northwest Fisheries Science Center in order to track and learn from changes that result from watershed restoration. This IMW has a unique, socio-economic component to its monitoring plan. 
The field of environmental management is increasingly interested in identifying compatible natural resource uses and management techniques that have socio-economic as well as biophysical benefits (Kelly and Bliss 2009; Hibbard and Karle 2001; Berkes and Folke 1998). Habitat restoration is a management technique with significant social and economic impacts to local communities (Pollin 2009; Morton and Padgitt 2005; Hibbard and Karle 2001). Habitat restoration encourages stewardship through environmental education and volunteer opportunities, provides local jobs, and enhances the value of ecosystem services provided by the restored habitats. For these and other reasons, researchers from University of Oregon and Oregon State University were contracted by the IMW to lead a participatory process to identify a series of socioeconomic metrics to be monitored by the IMW for the next ten years.

A socio-economic monitoring protocol was developed for collecting data on the direct and indirect effects of restoration activities in the Middle Fork on Grant County by tracking 17 different direct effects, outcome measures, and socio-economic indicators (Hibbard and Lurie 2009). The metrics are listed in Table 1. "Changes in land use/land management practices - on public, tribal and private lands throughout Grant County” is one of the outcome measures. The research described herein was conducted to contribute data on this measure to the IMW socio-economic monitoring project.

This study uses in-depth interviews to explore understandings of changing local land use and land management practices among residents of Grant County, Oregon. Changing land use and land management practices are defined as new or different techniques or approaches implemented on physical tracts of land. The practices involve 


\begin{tabular}{|c|ll|}
\hline & - Number and size (in dollars) of restoration contracts \\
Direct & - Local/non-local firm? (local = Grant County) \\
Effects & - \% of contract dollars spent locally \\
& - \% of employees who are local residents (local = Grant County) \\
& - & Chamber of new "restoration-related" jobs \\
\hline & & lands throughout Grant County. \\
Outcome & - Annual travel spending in Grant County \\
Measures & - Estimated number of jobs generated by travel spending in Grant County \\
& - Total local lodging tax receipts for Grant County \\
& - Camping activity \\
\hline Socio- & - Total population \\
economic & - Population by age \\
Indicators & - Median household income \\
& - Non-farm employment \\
& - Total payroll \\
\hline
\end{tabular}

Table 1: Socio-economic metrics being monitored in the Middle Fork Intensively Monitored Watershed in Grant County, Oregon (Hibbard and Lurie 2009).

utilizing, manipulating, augmenting, or making a profit off of natural resources such as water, rangeland, forest, fish and wildlife, or plant communities. As part of the IMW socio-economic monitoring project, these interviews with residents of the community will help describe some of the direct and indirect impacts of restoration activities taking place within the IMW. The results of this study are intended to help identify and explore the complex, dynamic, place-based impacts of habitat restoration and help to understand what does and does not work in this community.

Specifically, the research aims of this study are to:

1) Document how landowners and natural resource managers from the Middle Fork and Grant County describe changes they’ve witnessed in land use and land management practices,

2) Explore the issues and values that landowners and natural resource managers identify as influencing their land use and land management practices, 
3) Identify ways in which private landowners are adapting to changing land use and land management practices in their community, and

4) Recommend steps that natural resource management agencies, the IMW, and restoration practitioners can take to continue implementing high priority restoration actions while also contributing to the social and economic resilience of the community.

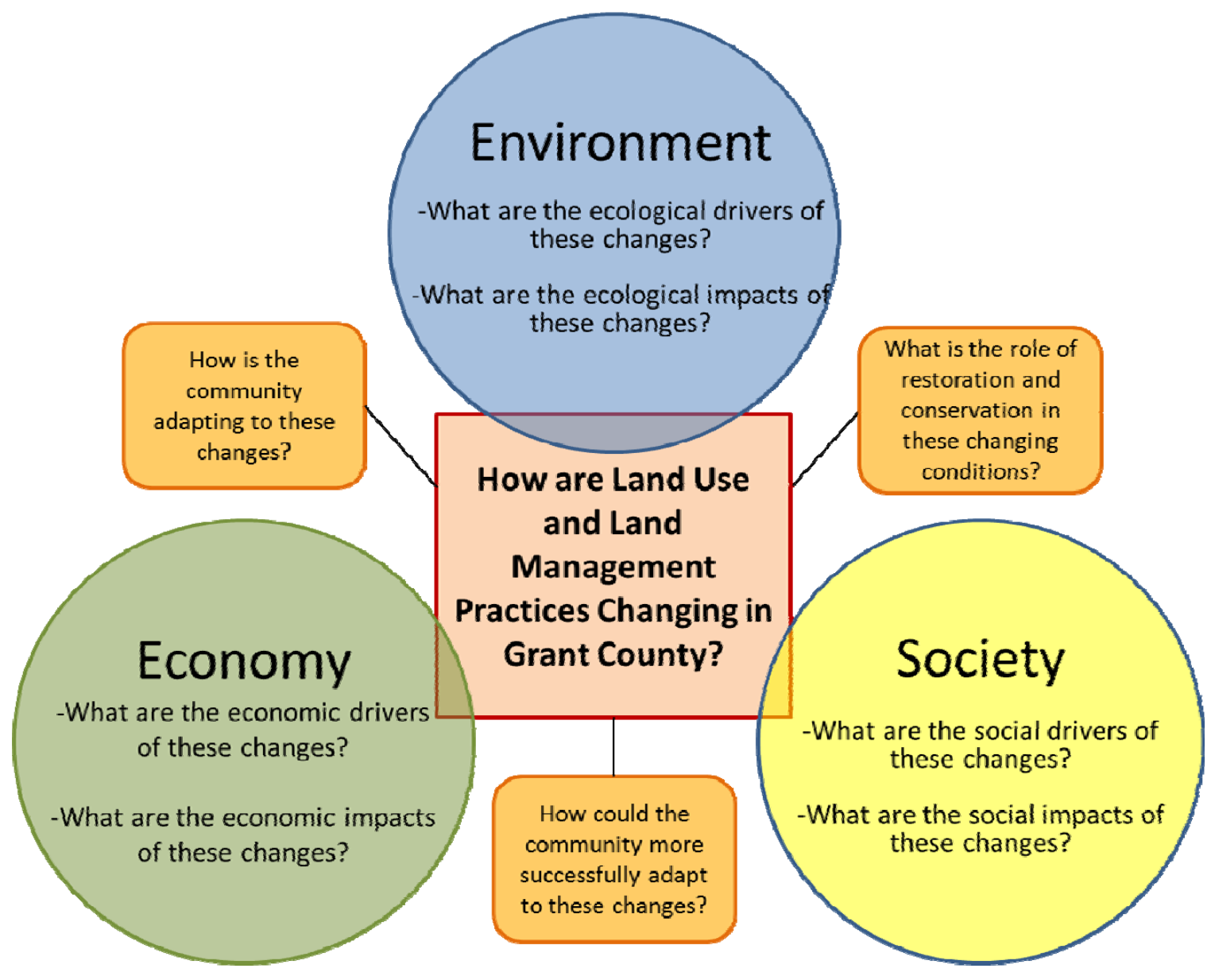

Figure 2: A Concept Map Depicting the Main Research Questions of this Study. These questions are situated amidst the various economic, social, and ecological drivers and impacts that effect natural resource use. 
A concept map for this study is presented in Figure 2. This concept map shows how the research questions relate to economic, environmental, and societal drivers of change as well as economic, environmental, and societal impacts of change. As changing land use and land management practices were documented through this research, their impacts and drivers were identified and grouped using these same categories. Figure 5 in the Results chapter builds upon this basic concept map by diagramming the most significant changes described.

By exploring the experiences of landowners and managers, the study gathers information and perspectives that can be used to better understand how and why different practices are being adopted. The synthesis provided by this study identifies ways of framing, motivating, and implementing land management practices that enhance the community’s economic, social, and ecological health, as described in the significant findings, opportunities, and recommendations sections of the Results and Discussion chapters. This information will help improve practice and inform policy on natural resource use, community-based natural resource management, habitat restoration, and community resilience. While the watershed enhancement and monitoring activities of interest to this study are concentrated in the Upper Middle Fork of the John Day River because of its designation as an IMW, restoration is a developing discipline throughout the Northwest, the US, and the world, and it is hoped this research will have implications beyond the community in which it was conducted. 


\section{Site and Populations Selection}

Grant County, Oregon provides a unique opportunity for exploring social and cultural understandings of restoration and its impacts. Grant County is a rural, natural resource-dependent community strongly tied to its roots, having been one of the first mining towns in the wild West (Grant 1993; Bureau of Reclamation 2008). Grant County contains about 65\% public lands, multiple national protected areas, and several reaches of the John Day River and its tributaries are designated as Wild and Scenic (National Wild and Scenic Rivers 2011). In 2002 the community’s resistance to federal regulation and emphasis on libertarian values led the county to declare itself a United Nations-free zone and authorize the public to cut trees on federal lands regardless of federal authorities (Enders 2002). Though these ballot measures remain unrecognized by federal and state governments, they have contributed to Grant County’s reputation as a particularly antiregulatory, natural resource-dependent sample of rural America. The county residents share many traits with proponents of the "Wise Use” movement, who prefer county level governance over federal law and insist that natural resource stewardship entails harvest, use, and extraction (McCarthy 2002).

Yet, in the wake of several Endangered Species Act listings throughout the Columbia Basin, the federal government and environmentalists are increasingly prioritizing recovery of the wild, undammed salmon runs in the John Day Basin (Columbia-Blue Mountain Resource Conservation and Development Area 2005). An influx of resources are pouring into Grant County for the purpose of salmon habitat restoration (Oregon Explorer 2011). With the Upper Middle Fork of the John Day 
River's designation as an Intensively Monitored Watershed in 2008, the priority of the work there became apparent. As Figures 3 and 4 depict, restoration projects have been implemented within the Middle Fork subbasin for over a decade, but since its designation as an IMW the size of investments in restoration have increased considerably. This recent shift has implications for social and economic conditions in the area, which are explored throughout this study.

Concern over shifting natural resource management priorities and their effects on the social and economic viability of the community have long been of concern in Grant County (Bromley, Blanch and Stoevener 1968). With the current unemployment rate at $13 \%$, competing demands and pressures on the economy are as important as ever (Worksource Oregon 2011). No other Oregon County has had as many consecutive years of job loss as Grant County (WorkSource Oregon 2009). Grant County is also one of only a few counties in Oregon where the population is currently decreasing (Table 2). Amidst these significant social and economic challenges, the effects and opportunities created by natural resource management activities may be of particular interest. 


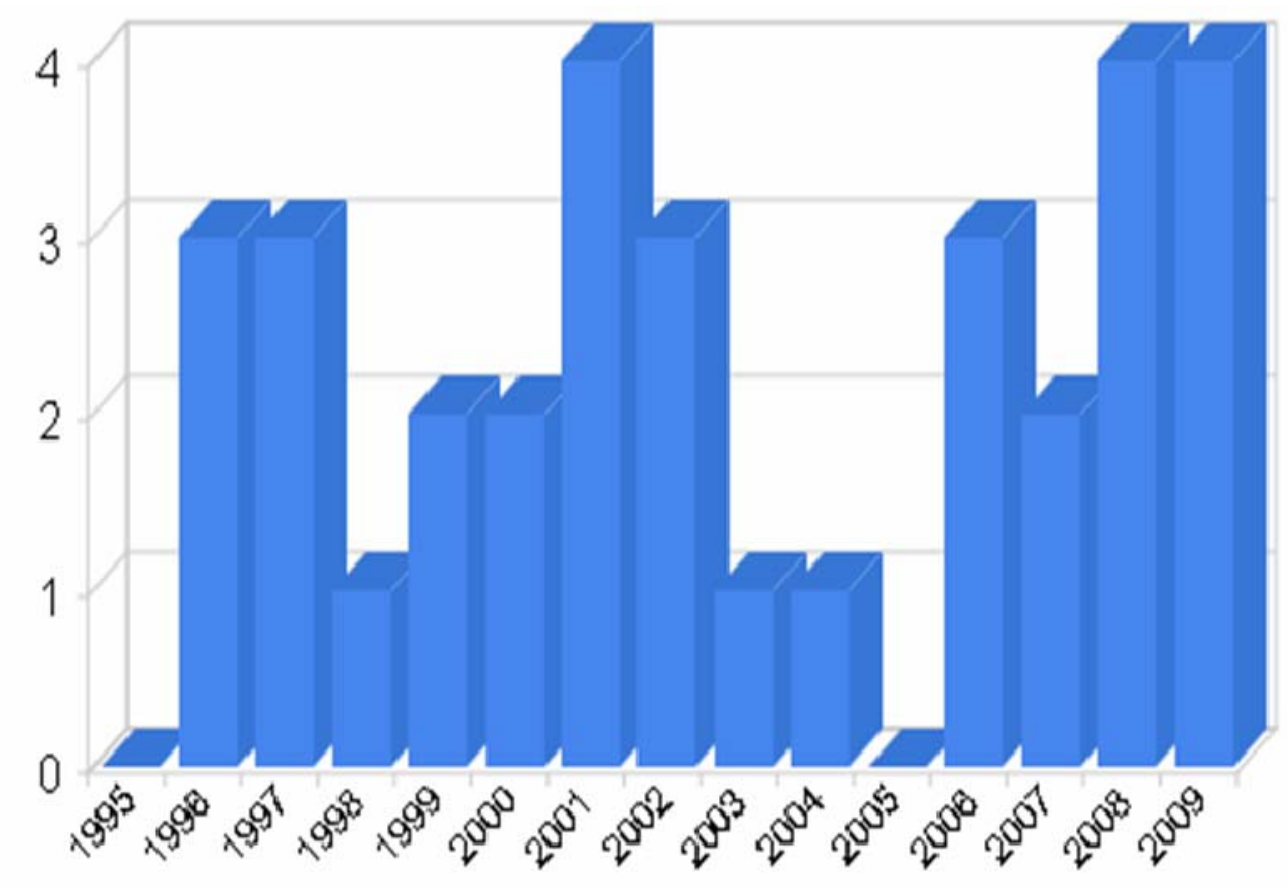

Figure 3: Number of Restoration Projects Implemented in the Middle Fork Subbasin, 1995-2009. Source: Oregon Explorer 2011.

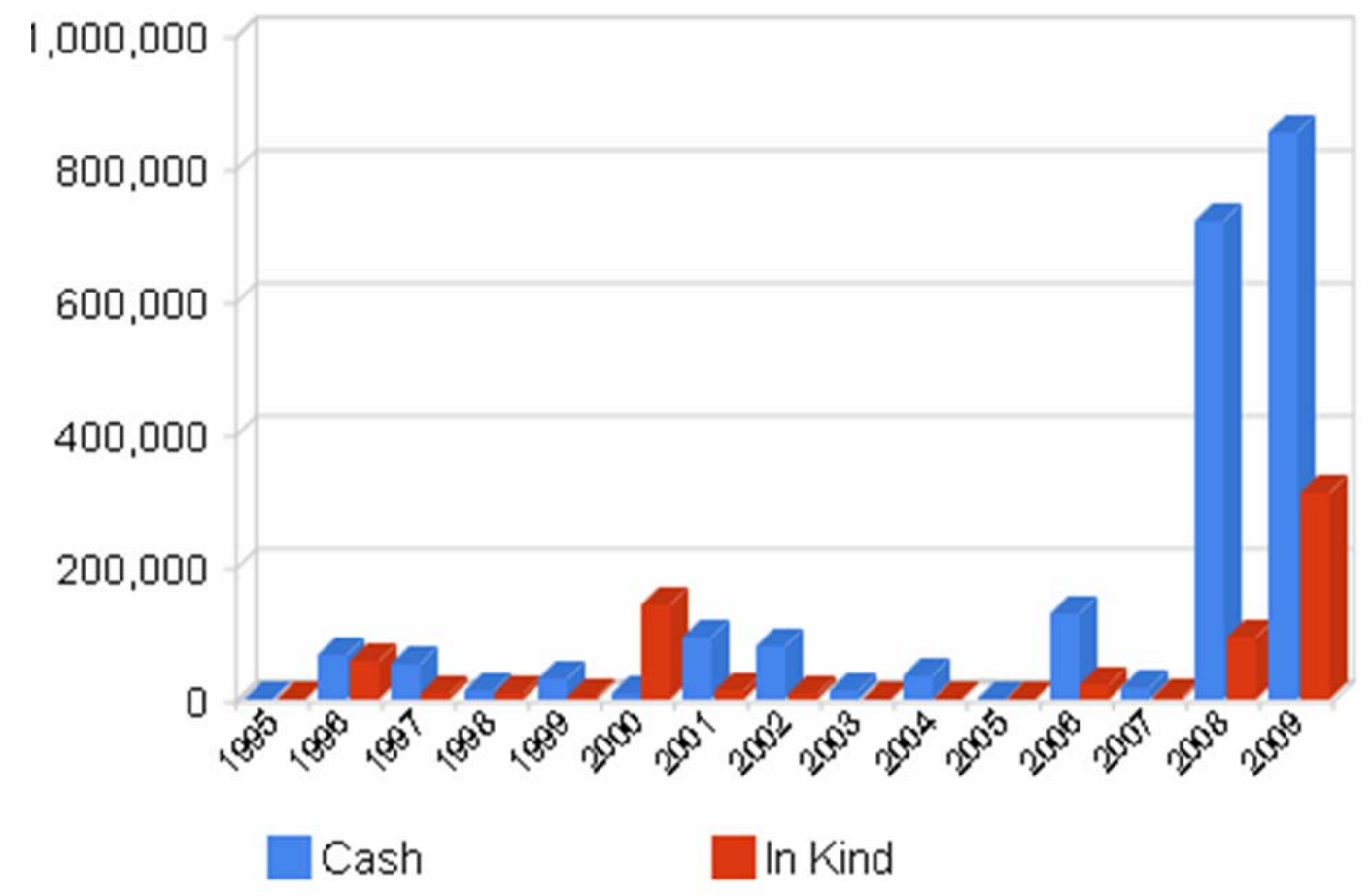

Figure 4: Investments (both Cash and Inkind) in Restoration Projects in the Middle Fork Subbasin, 1995-2009. Source: Oregon Explorer 2011. 


\begin{tabular}{|c|c|c|c|c|c|c|}
\hline & $\begin{array}{l}\text { July 1, } 2009 \\
\text { Population } \\
\text { Estimate }\end{array}$ & $\begin{array}{c}\text { April 1, } 2000 \\
\text { Census } \\
\text { Population }\end{array}$ & $\begin{array}{c}\text { Population } \\
\text { Change } \\
2000-09\end{array}$ & $\begin{array}{l}\text { Percent } \\
\text { Change } \\
2000-09\end{array}$ & $\begin{array}{c}\text { Natural } \\
\text { Increase } \\
2000-09\end{array}$ & $\begin{array}{c}\text { Net } \\
\text { Migration } \\
2000-09 \\
\end{array}$ \\
\hline OREGON & $3,823,465$ & $3,421,399$ & 402,066 & $11.8 \%$ & 147,740 & 254,326 \\
\hline \multicolumn{7}{|l|}{ Counties } \\
\hline BAKER & 16,450 & 16,741 & -291 & $-1.7 \%$ & -391 & 100 \\
\hline BENTON & 86,725 & 78,153 & 8,572 & $11.0 \%$ & 2,601 & 5,971 \\
\hline CLACKAMAS & 379,845 & 338,391 & 41,454 & $12.3 \%$ & 11,693 & 29,761 \\
\hline CLATSOP & 37,840 & 35,630 & 2,210 & $6.2 \%$ & 285 & 1,925 \\
\hline COLUMBIA & 48,410 & 43,560 & 4,850 & $11.1 \%$ & 1,073 & 3,777 \\
\hline coos & 63,065 & 62,779 & 286 & $0.5 \%$ & $-2,024$ & 2,310 \\
\hline CROOK & 27,185 & 19,182 & 8,003 & $41.7 \%$ & 356 & 7,647 \\
\hline CURRY & 21,340 & 21,137 & 203 & $1.0 \%$ & $-1,525$ & 1,728 \\
\hline DESCHUTES & 170,705 & 115,367 & 55,338 & $48.0 \%$ & 6,499 & 48,839 \\
\hline DOUGLAS & 105,395 & 100,399 & 4,996 & $5.0 \%$ & -973 & 5,969 \\
\hline GILLIAM & 1,885 & 1,915 & -30 & $-1.6 \%$ & -53 & 23 \\
\hline GRANT & 7,525 & 7,935 & -410 & $-5.2 \%$ & -225 & -185 \\
\hline HARNEY & 7,715 & 7,609 & 106 & $1.4 \%$ & 53 & 53 \\
\hline HOOD RIVER & 21,725 & 20,411 & 1,314 & $6.4 \%$ & 1,216 & 98 \\
\hline JACKSON & 207,010 & 181,269 & 25,741 & $14.2 \%$ & 2,476 & 23,265 \\
\hline JEFFERSON & 22,715 & 19,009 & 3,706 & $19.5 \%$ & 1,346 & 2,360 \\
\hline JOSEPHINE & 83,665 & 75,726 & 7,939 & $10.5 \%$ & $-2,174$ & 10,113 \\
\hline KLAMATH & 66,350 & 63,775 & 2,575 & $4.0 \%$ & 1,038 & 1,537 \\
\hline LAKE & 7,600 & 7,422 & 178 & $2.4 \%$ & -137 & 315 \\
\hline LANE & 347,690 & 322,959 & 24,731 & $7.7 \%$ & 6,274 & 18,457 \\
\hline LINCOLN & 44,700 & 44,479 & 221 & $0.5 \%$ & -859 & 1,080 \\
\hline LINN & 110,865 & 103,069 & 7,796 & $7.6 \%$ & 3,390 & 4,406 \\
\hline MALHEUR & 31,720 & 31,615 & 105 & $0.3 \%$ & 1,762 & $-1,657$ \\
\hline MARION & 318,170 & 284,834 & 33,336 & $11.7 \%$ & 20,652 & 12,684 \\
\hline MORROW & 12,540 & 10,995 & 1,545 & $14.1 \%$ & 777 & 768 \\
\hline MULTNOMAH & 724,680 & 660,486 & 64,194 & $9.7 \%$ & 38,199 & 25,995 \\
\hline POLK & 68,785 & 62,380 & 6,405 & $10.3 \%$ & 2,289 & 4,116 \\
\hline SHERMAN & 1,830 & 1,934 & -104 & $-5.4 \%$ & -25 & -79 \\
\hline TILLAMOOK & 26,130 & 24,262 & 1,868 & $7.7 \%$ & -194 & 2,062 \\
\hline UMATILLA & 72,430 & 70,548 & 1,882 & $2.7 \%$ & 4,081 & $-2,199$ \\
\hline UNION & 25,470 & 24,530 & 940 & $3.8 \%$ & 662 & 278 \\
\hline WALLOWA & 7,100 & 7,226 & -126 & $-1.7 \%$ & -131 & 5 \\
\hline WASCO & 24,230 & 23,791 & 439 & $1.8 \%$ & 33 & 406 \\
\hline WASHINGTON & 527,140 & 445,342 & 81,798 & $18.4 \%$ & 45,302 & 36,496 \\
\hline WHEELER & 1,585 & 1,547 & 38 & $2.5 \%$ & -93 & 131 \\
\hline YAMHILL & 95,250 & 84,992 & 10,258 & $12.1 \%$ & 4,489 & 5,769 \\
\hline
\end{tabular}

Table 2: Population Change in Oregon Counties, 2000 to 2009. Source: Population Research Center 2010. Note, Grant County has experienced the second highest percent population decrease in the state during this time period. 


\section{Chapter 2: Literature Review}

\section{Monitoring the Socio-economic Impacts of Habitat Restoration}

Habitat restoration is an evolving science that crosses ecological, social, and economic disciplines. In the Pacific Northwest, fish habitat restoration has grown into a mutli-billion dollar venture (Wu et. al. 2003). As the industry has developed, interest in assessing the effectiveness of various restoration techniques and practices through monitoring has increased. Surprisingly, there has been little analysis of the effects of restoration techniques and practices, as successful monitoring is time consuming, expensive, and complicated (Kershner 1997). What monitoring does take place is usually focused on the biological and physical aspects of an ecosystem at the individual project level (Roni 2005; Thayer et. al. 2005).

Interest in tracking the social and economic impacts of habitat restoration is intensifying. Green jobs, the restoration economy, and climate change have been placed on the national agenda and are drawing increased attention to the social and economic impacts of restorative land management practices (Nielson-Pincus and Moseley 2010; Moseley and Wilson 2002; Flora et. al. 1999). Nationwide, restoration practitioners, city planners, government agencies, and individual communities are attempting to track the effects of restoration work on the economy and society (Hibbard, Guerwitz, and Roark 2009; Morton and Padgitt 2005; Spurgeon 1999). Land and watershed restoration has been found to create up to 39.7 direct, indirect, and induced jobs for every million dollars invested (Pollin et. al. 2009). Oil and gas projects, in contrast, create just 5.2 jobs per 
million dollars invested, while road repair projects create 20.3 jobs per million dollars invested.

The contributions of the natural resource economy are generally measured in terms of either impacts or values (Freeman 1993, Lipton et. al. 1995). Economic impacts include direct or indirect effects, such as job creation in the natural resource sectors, contracts awarded for restoration projects, or changes in property values as a result of a different land use practices. Economic values include intrinsic or existence values, such as what it's worth to know a river flows free from its headwaters to the ocean or that a 300 year old tree lives in the forest. Economic valuation can also include placing values on activities the public enjoys for free, such as bird watching, hiking, or recreational fishing. Most of the socio-economic variables being monitored by the Middle Fork IMW measure the direct or indirect economic impacts of the restoration activities. The socio-economic measures being tracked by the Middle Fork IMW are listed in Table 1. $\underline{\text { Social Impacts and Values }}$

The social impacts and values of habitat restoration can also be monitored. Given the politicized nature of salmon habitat restoration in the Pacific Northwest, the social aspects of the practice in many cases determine the success or failure of a project more concretely than the physical aspects do (Wu et. al. 2003). In some cases these human dimensions even drive the restoration techniques that can be practiced. As Naveh (2005) posits, embracing the transdisciplinary nature of restoration is essential for the field to move from a science to a practice since incorporating the human component of the ecosystem is necessary for project implementation. 
Social values are intrinsic to habitat restoration. What is restored, what state it is restored to, and how that restoration is prioritized compared to other projects and needs in a community are all value-laden decisions. Davis and Slabodkin (2004) go as far as to suggest the following revised definition of ecological restoration: “Ecological Restoration is the process of restoring one or more valued processes or attributes of a landscape. (p. 2)', They contend that the field of restoration has concentrated too heavily on defending the scientific basis of restoration and in doing so has ignored or even denied the sociological drivers and impacts of the practice.

Acknowledging the need for further exploration of the social impacts and values of habitat restoration, this study uses the theoretical constructs of community-based natural resource management, sense of place, and social-ecological system resilience to better understand the role of habitat restoration in the communities of the Middle Fork John Day and Grant County. This enhanced understanding of social impacts and values will help to identify new approaches, paradigms, and perspectives that can be applied to the community’s current day natural resource management challenges.

\section{Community-based Natural Resource Management}

As the previous discussion of social values and impacts conveys, the relationship between land management activities and local socio-economic conditions is not one way. Restoration affects jobs, resilience to climate change, and an individual's connection to the land. Individuals and communities, however, also drive when, where, and how different land management practices occur. Folke (2002) and others describe ecological and human systems as inextricably linked. In his article on resilience and sustainable 
development, Folke identifies the assumption of human and ecological systems as separate, discrete realms as one of the fundamental errors of natural resource policy to date.

Social factors are often responsible for a disconnect between management goals and practices. As numerous studies have shown, natural resource planning that has occurred with little local input rarely succeeds in achieving its goals, no matter how scientifically sound they may be (Christian-Smith and Merenlender 2010; Bowcutt 1999). Over the past decade, the importance of considering human communities has become increasingly valued in the field of habitat restoration (Naveh 2005). Healthy communities are being recognized and valued as essential to successful natural resource management practices (Kelly and Bliss 2009).

Societal acceptance and value of restoration work is important on both public and private lands. Habitat in need of restoration can be found on both ownership types. The individual species and ecological processes being restored are rarely contained by land management patterns, so coordinated management across private and public lands is desired. Successful restoration requires a significant degree of support from the individuals and communities affected. Social value, understanding, and trust are all key components to societal acceptance and the long term success of restoration activities. $\underline{\text { Social Values and Public Land Management }}$

As Davenport et. al. (2007) describe, trust in federal natural resource management agencies is particularly important for communities that neighbor public lands. As their research with a National Tallgrass Prairie managed by the Forest Service in Illinois 
illustrates, though public participation in decision making on public lands is required through the National Environmental Policy Act (NEPA), communities often feel as though their values are not truly acknowledged or appreciated by the NEPA process. In particularly challenging scenarios, public disagreement with agency management results in litigation, as has been the case in many natural resource dependent communities, including Grant County. A community-based approach to natural resource management seeks to engage a variety of stakeholders early and often so that management is representative of the public interest (Brosius et. al. 1998). Community-based management takes a proactive approach to exploring natural resource issues and resolving disagreements at the local level in an attempt to find sustainable solutions and prevent divisive issues from ending up in the courts.

$\underline{\text { Social Values and Private Land Management }}$

Understanding a community's social structure and values significantly enhances the likelihood that a natural resource management practice will succeed. Conservation practices must be based in common values and result in reliable, direct benefits that the community can measure and believe in if they are to be successful on private lands (Bewsell et. al. 2007; Kauneckis and York 2009; Lovell and Sullivan 2006). In a study on conservation buffer adoption among farmers and other private landowners, Lovell and Sullivan (2006) found that social, economic, and public policy issues all affect whether or not such buffers are adopted. They found that conservation buffer programs like the Conservation Reserve Enhancement program (CREP) have not been as popular as anticipated, largely because the costs of building and maintaining the buffers outweigh 
the payments received for setting the land aside, so landowners do not enroll. Similarly, in a study of private landowner participation in voluntary forest conservation programs, Kauneckis and York (2009) found socio-economic factors to be most strongly correlated with adoption of conservation practices. Through in-depth interviews they discovered land use activity and the variety of land types within a single landowner's possession were the most indicative factors of whether a landowner engaged in the voluntary practices.

\section{Local Participation}

Community-based, collaborative environmental management is an important approach to finding solutions that address the varied needs of multiple stakeholders (Lauber 2008; Margerum 2008). Local involvement and collaboration are necessary so that management practices reflect the values of managers and the community. A participatory process also exposes local stakeholders to the varied values represented by individuals and groups within their community.

Collaborative, interdisciplinary, participatory processes have been used in Grant County already with mixed results. The US Forest Service and Bureau of Land Management (BLM)'s Interior Columbia Basin Ecosystem Management Project was challenged by issues of scale and communication (Jakobsen 2004). More recently, the Northwest Power and Conservation Council's Columbia Basin Fish \& Wildlife Program succeeding in drafting a John Day Basin Plan in large part thanks to the leadership of a local organization with roots in the community (Columbia-Blue Mountain Resource Conservation and Development Area 2005). The Blue Mountain Forest Partners, a 
collaborative, consensus-based group that works on forest stewardship in Grant County, have progressed beyond plan development to the successful implementation of several projects (Blue Mountain Forest Partners 2009).

\section{$\underline{\text { Adaptive Management }}$}

The ability to adapt to change is a necessary component of collaborative efforts. The concept of adaptive management has been adopted as a useful practice for responding to the unpredictable biophysical and socio-cultural effects of restoration. In their work on environmental values Norton and Steinemann (2001) highlight the role of adaptive management in community-based natural resource management. They suggest that adaptive management may be a useful tool for engaging diverse social values. To this end they have identified three core principles for adaptive management, which are outlined below:

“1. Experimentalism. Adaptive managers emphasise experimentalism within a dynamic system, recognising that an ongoing search for knowledge is necessary to set and achieve environmental goals.

2. Multi-scalar Analysis. Adaptive managers model and monitor natural systems on multiple scales of space and time.

3. Place Sensitivity. Adaptive managers adopt local places, understood as humanly occupied geographic places, as the perspective from which multi-scalar management orients” (p. 477).

This final principle, place sensitivity, is particularly important to community-based restoration efforts. Sense of place can be a unifying, polarizing, or informative concept 
for understanding how individuals relate to their environment (Williams and Patterson 1996; Cheng et. al. 2003; many others). Having sensitivity and awareness of sense of place in a community can greatly enhance the outcomes of community-based natural resource management efforts.

\section{Sense of Place}

Sense of place has been shown to relate to natural resource management in a variety of ways (Davenport and Anderson 2005; Cheng et. al. 2003; Yung et. al. 2003). For one, it expands the classic human-environment relationship beyond resource extraction and allows for a more nuanced, personal, and social understanding of humans and their environment. In their article on "Place as an Integrating Concept in Natural Resource Politics,” Cheng and colleagues (2003) offer a number of propositions on how sense of place is important to natural resource management. One of their propositions is that people's feelings and reactions towards natural resource management are related to their social groupings and the common sense of place those groupings share. New and different management activities can alter those social groupings or the sense of place which that group shares.

Another way sense of place relates to natural resource management is through its implications for participation and expanding the social values represented in decision making processes. Cheng and colleagues suggest in-depth interviews, participant observation, surveys, and other qualitative research methods that allow for a depth and breadth of understanding not found through other modes of community engagement. As they described it, "Conducting place-based social research provides more than data for 
decision makers. It transforms the decision making process itself by redistributing power to voices and meanings that may not otherwise be expressed. In general, natural resource politics has been dominated by organized interest groups, commodity industries, elected officials, scientific experts, and resource specialists" (p100).

In their work on the Rocky Mountain Front in Colorado, Yung et. al. identify place as a useful concept for getting beyond politicized disagreements to find common ground: "Place-based management is growing, and specific benefits have been postulated, including more efficient planning, ability to build on common ground, reduced conflict and litigation, and more enduring management plans.... And, knowledge of the meanings of particular places may help managers to understand why specific proposals are contentious and when conflict might emerge" (2003, p.856).

In Grant County, past and present litigation has largely posed "environmentalists" against “ranchers,” or "citizens” against "big government.” This culture clash is not unique to Grant County (Smith and Krannich 2000). But acknowledging that these social groups have distinct identities and cultures could be a big step forward in resolving the existing conflicts (McCarthy 2002). Exploring sense of place through in-depth interviews with individuals already involved in or witness to conservation-oriented practices will help to identify common ground and hopefully move beyond some of the polarized groupings that have emerged in this community.

As a natural resource dependent community in Oregon facing similar issues, Grant County might benefit from place-based research that was conducted in Southwestern Oregon around spotted owl issues in the late 1980s and early 1990s. As 
Yung et. al. explain, "In the case of the spotted owl, the conflict was most often characterized as a collision between conservation and livelihood, represented in the slogan "jobs versus owls." Livelihood was seen as the domain of the local community while conservation existed elsewhere, presumably in urban centers. This characterization of the conflict reduced a complex social landscape to a dualistic, commodity-oriented disagreement” (2003, p.856).

In order to better understand the “complex social landscape” described above, Brown conducted a series of interviews in Jackson and Josephine Counties. Through this research the role of the media was identified as a strong, polarizing force that was not necessarily founded in the lived experiences of Oregon residents (1995). The influx of new residents from urban areas with different views was also identified as a compounding factor in the emotional charge that built up around the spotted owl issue. Changing social values and impacts can have significant implications for natural resource management in rural areas where sense of place plays a large role in community identity (Field et. al. 2003). Collaboration around natural resource management issues using the concepts of shared ideology and sense of place have proved successful in other northeastern Oregon communities (Waage 2001).

The ways that landscapes change generally result in changes in how people relate to those landscapes. Understanding sense of place may be particularly important in communities where significant change is underway (Davenport and Anderson 2005), such as Grant County. As was mentioned earlier, natural resource management decisions often cause changes that then affect place meanings for individuals in the community 
(Cheng et. al. 2003; Field et. al. 2003). Encouraging community-based approaches to natural resource management and monitoring the social effects of that management can help natural resource agencies and communities to understand, anticipate, and plan so that they are adaptable to change as it happens.

\section{Resilience of Social-Ecological Systems}

The ability of social systems and ecological systems to adapt to change is of particular importance in communities that are highly dependent upon their natural resources base. In his book, Lost Landscapes and Failed Economies: The Search for a Value of Place, Power recounted similar stories of boom and bust in logging, mining, and ranching communities throughout the American West. He suggests that new perspectives on social, economic, and ecological resources are needed to move beyond this trend of communities dying along with depletion of their natural resource base.

The concept of resilience has been embraced as a useful construct for understanding response to change in social and ecological systems (Holling 1973). As Folke et. al. (2002) describe it, "Resilience, for social-ecological systems, is related to (i) the magnitude of shock that the system can absorb and remain within a given state; (ii) the degree to which the system is capable of self-organization; and (iii) the degree to which the system can build capacity for learning and adaptation" (p. 438). They go on to describe the resiliency of social-ecological systems as integral to our understanding of natural resource policy and management.

Resiliency theory is being embraced by natural resource managers already. In their review of the integration of resilience into natural resource management, Benson 
and Garmestani found that in the United States the US Forest Service, US Fish and Wildlife Service, Bureau of Reclamation, and NOAA Fisheries all refer to resiliency in their management plans, mission statements, or visions (2011). The researchers suggest that existing regulatory requirements may limit how significantly resilience can be incorporated into current practices, particularly since many laws focus on preserving or restoring to a previous state rather than envisioning a more robust future condition. They also found that it is difficult for natural resource agencies to address social and ecological system resilience together. Though there are clearly many challenges to successfully adopting resiliency theory in natural resource management, the concept is gaining ground.

Humans are unique in that we have foresight and can use our adaptive and innovative capabilities to take advantage of opportunities and avoid catastrophes in social, ecological, and physical systems (Biggs et. al. 2010; Holling 2001). Natural resource managers are tasked with avoiding such catastrophes and as such are exploring ways to integrate resiliency theory beyond policy and into management. The concept of adaptive management, described in further detail previously in the section on communitybased natural resource management earlier, is proposed as one way to apply resiliency theory to this field (Benson and Garmestani, 2011). The three tiered approach to sustainability provides another useful framework, encouraging a balance of ecological, social, and economic considerations in decision making and planning for the future (United National General Assembly 1987 and 2005). 
The research conducted here considers social-ecological system resilience, sense of place, and community-based natural resource management in relation to the social impacts and values of habitat restoration taking place in the Middle Fork Intensively Monitored Watershed and elsewhere in Grant County. Because habitat restoration has become a common conservation practice among natural resource managers in the area, there is interest in exploring how the practice may be impacting the resilience, character, and socio-economic conditions of the county. By speaking with landowners and agencies already involved in conservation-oriented activities this research is examining how people currently value, utilize, and benefit from restoration, among other conservation practices. Specifically, this research seeks to document changing land use and land management practices, explore the drivers of these changing practices, identify how land managers are adapting to these changes, and finally to highlight examples of successful adaptation and common ground that others might find useful as they respond to the changing socio-economic conditions in Grant County. It is hypothesized that by engaging perspectives that have not yet been part of the dialogue around natural resource management in the area, this research will uncover place-based solutions that will lead to a more resilient social-ecological system. 


\section{Chapter 3: Methods}

\section{Research Design}

\section{$\underline{\text { Data Collection }}$}

In-depth interviews were conducted with 17 landowners, managers, or residents from the Intensively Monitored Watershed (IMW) and elsewhere in Grant County in order to gain an understanding of their experiences of changes in land use and land management. In-depth interviews were chosen as the most data-rich qualitative research technique that could be used to gather value-laden and personal perspectives on past, present, and future practices, decision making, and concerns (Charmaz 2006). It was also suspected that given the extremely busy, hands-on, and independent lifestyles led by most of the interviewees, one on one conversational interviews had the greatest potential to engage the study participants and elicit sincere and thoughtful responses. Life history methodology was employed to capture the individual's personal experience and understanding of changes in land use and land management during their lifetimes.

An interview guide was developed so that the same questions were asked of every study participant (see the Interview Guide in Appendix A). The open ended, semistructured formatting of the questions in the interview guide kept the interviews somewhat conversational and allowed participants to prioritize and describe in detail the components of the questions that mattered most to them (Charmaz 2006). The questions encouraged the participants to describe past, present, and future land use practices in Grant County, identify issues and values associated with their land use practices over time, and explore how they felt about changing practices in their community. The 
interview guide was modified slightly during the initial interviews as early study participants provided insights into specific practices, issues, or language that could improve the quality of subsequent interviews.

Another strength of the in-depth interview methodology was that the interviews could be conducted nearly anywhere. In many cases the settings of the interviews provided rich observational data. The most common location for the interviews was in the participant's home. Many interviews were conducted outdoors on the participant's property. Offices, a restaurant, and a restoration project site all served as interview locations as well. Wherever they took place, the interviews were always recorded with a digital audio recording device. Field notes were taken when possible. Participants signed informed consent forms before the interviews began (see the Informed Consent Form in Appendix B). Approval was received by the Human Subjects Research Review Committee at Portland State University before the research began (see Appendix C. Human Subjects Approval and Appendix D. Human Subjects Extension Approval).

\section{Sampling Technique}

The residents were identified through purposive and snowball sampling techniques (Marshall and Rossman 2006). An initial sample of 8 public and private landowners from within the IMW (see Figure 1) and 5 private landowners from elsewhere in the county was identified by the study's key informant, the County Judge. The County Judge was selected as the key informant of this study based upon his expertise and standing within the community. Grant County operates with a County Court system which is led by three elected County Commissioners. The Chair of the 
Board of County Commissioners is titled the County Judge. Grant County's current County Judge, Mark Webb, is keenly interested in natural resource management, community, resilience, and sustainability issues. He frequently participates in the IMW meetings, sits on several state and local committees such as the Governor's Sustainability Board and Rural Voices for Conservation Coalition, and has testified to the US Congress on natural resource management legislation. The key informant provided email, in person, or telephone introductions for the researcher to potential participants.

After this initial purposive sampling effort, snowball sampling was then employed to identify additional key landowners, managers, and local experts who could provide descriptions and stories that highlighted land management changes in Grant County. In some cases the initial study participants also provided a telephone or in person introduction to additional potential participants. The researcher followed up on introductions with a phone call or visit to further explain the research and schedule an interview with the potential participants.

In total 17 individuals representing 16 different households, organizations, or agencies from the IMW and elsewhere in Grant County were interviewed between August 2010 and June 2011. This study originally proposed to interview between 12 and 20 individuals and to terminate interviewing once the researcher reached theoretical saturation, defined by repetition and a void of relevant new knowledge emerging in the coding and analysis of two interviews in a row (Glaser and Strauss 1967; Guest et. al. 2006). This goal was amended so that the interviews were terminated when all of the major landowners within the IMW had been interviewed. Unfortunately there was one 
Middle Fork landowner who was contacted by the researcher and agreed to interview but could not be scheduled within the timeframe of this study.

Given the informal settings of most of the interviews, it sometimes proved difficult to conduct an interview with just one individual. In several cases marital partners or friends entered the conversation and sometimes participated in part of the interview. Only one interview was conducted from start to finish with a couple and that interview is referenced as Interview 6/7. This single interview represents two individuals' perspectives but since they manage the same property they are considered to have a single land ownership. In the other interviews where multiple individuals participated the additional participants were identified as a unique individual within the transcript, but the interview was still considered just one interview. For example, Interview 3 included responses from respondents 3a and 3b, but only 3a was considered a participant in the study.

Of the 17 interviewees, 11 lived or owned land in the Middle Fork Subbasin, and an additional 2 leased land along the Middle Fork. The remaining 4 lived elsewhere in Grant County and were identified by the key informant or other study participants as being particularly knowledgeable about how land and water management practices have changed in their community. Additional demographic information about the 17 participants is presented in Table 3. 
to by that number, often with some other descriptive traits such as the ones outlined in Table 3. The only exception to this policy was in the cases of the public, non profit, and tribal employees interviewed. These organizations have such distinct characteristics when compared to other landowners on the Middle Fork that it was not possible to avoid referencing those organizations by name, though the individuals interviewed are never referenced by name. Interestingly, because each of those organizations are at least partially funded with public money, much information about their management practices and organizational histories is already publicly available. Anonymity was not promised to any of the research participants but care was taken to prevent the disclosure of personal or sensitive information.

\section{Data Processing}

The recorded interviews were transcribed manually by the researcher (Marshall and Rossman 2006). A draft copy of their transcript was sent to each interview participant either by email or regular mail. The participants were each provided with at least 30 days to review the transcript and respond with comments or corrections. Once comments were received or the agreed upon time period for review by the participants had passed, the transcripts were finalized. The transcriptions were then coded for common themes. Example coding categories are shown in Table 4. 


\section{LANDOWNERSHIP:}

- Middle Fork, Grant County, both

- Landowner, land manager, resident, non-resident

- Public, private, absentee, leasee

- Roots in the County, new, years of residence

\section{LAND USE CHANGES:}

- Ecological- Riparian vegetation, fencing, thinning, juniper control

- Social- Fewer ranching families, fewer schools, shifting values

- Political- East/West Oregon polarization, ESA litigation

- Cultural- Ranching lifestyle, accepting restoration, resisting restoration

- Economic- Economics of cattle production, development pressure, job opportunities

\section{FACTORS IN DECISION MAKING:}

- Finances

- Ecological Benefit

- Mutual benefit

- Management Plan

EMERGENT THEMES

- Balance

- Sustainability

- $\quad$ Single species focus of natural resource management agencies

- Importance of keeping ranches whole

\section{Table 4: Example Coding Categories}

\section{Data Analysis}

\section{Grounded Theory}

Data analysis was a highly iterative process based in grounded theory, where the data themselves informed the theory used to interpret the study’s findings (Glaser and Strauss 1967; Charmaz 2006). Grounded theory provided a flexible, yet systematic approach for data analysis in a qualitative study such as this. Initial interviews informed subsequent ones as ongoing analysis encouraged modifications of the interview guide and 
snowball sampling identified additional participants. As themes emerged, previously coded interviews were recoded to include emergent themes that were identified in subsequent interviews or through the analytic memo writing process. Memos, or structured analytic notes, were used to document connections, comparisons, and emergent concepts discovered in the process of data collection and analysis (Charmaz 2006). For instance, when a code was identified in response to multiple questions from the interview guide, a note such as this was written by the researcher to explore whether these responses might be related: "Sustainbility code appearing in interview responses on the topics of decision making, concerns, and expectations for the future. Sustainability may be an overarching theme to explore in more depth. Look for differences among private and non-private landowners in prevalence of sustainability code frequency in all three categories (decision making, concerns, future).” The researcher used these sorts of memos to explore relationships between and among the various codes and categories to look for larger themes and significant findings.

\section{$\underline{\text { Coding }}$}

Initial coding and interpretation of the memos was followed up by category development. The codes were grouped into categories and subcategories. Diagramming was used to explore relationships between and among the data (Strauss and Corbin 1998). The data were organized in a series of matrixes created in Microsoft Excel (see Figure 5 for an example of the matrix). The words, themes, and categories were grouped, counted, and compared using the matrix. Separate matrices were developed for individual questions from the interview guide, groups of questions from the guide, or emergent 
themes. Colors were assigned to different codes in order to assist the researcher in identifying and verifying additional connections, themes, and significant findings. The codes and emergent themes were not evaluated statistically. Instead, they were loosely quantified using the matrix. A detailed quantification of the interview responses can be found in Appendix E.

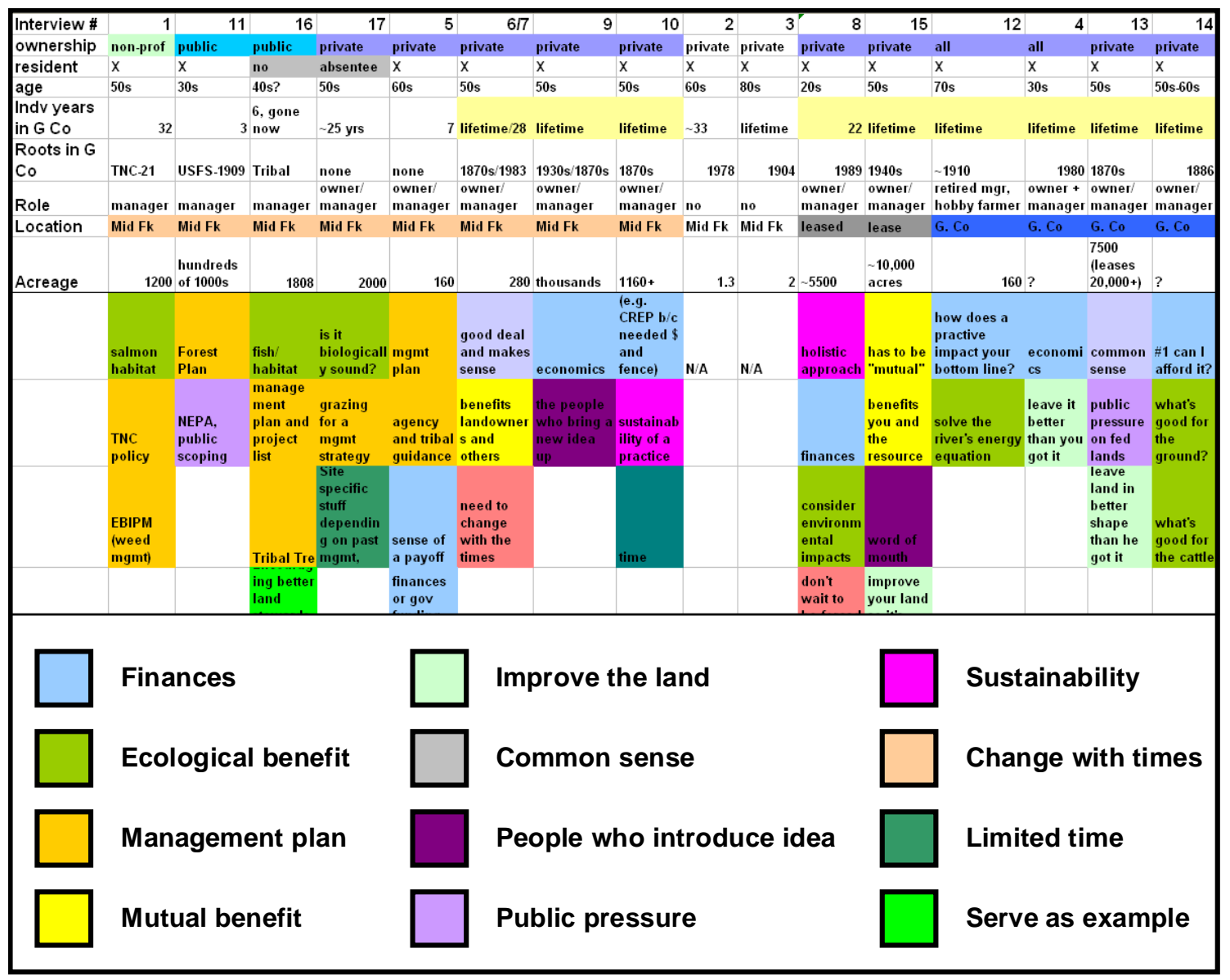

Figure 5: Example of a Matrix Developed for Qualitative Data Analysis. This sample matrix summarizes the interview responses related to how landowners make decisions about how to manage their land. The legend shows the codes and colors assigned to different responses. 


\section{$\underline{\text { Key Interviews }}$}

The relative priority, applicability, and strength of various themes was qualitatively assessed by the researcher. From this assessment three of the interviews were identified as "key interviews” because of the quantity and quality of data gathered from them as well as the level of respect they were referred to with by others in their community. Each of these individuals were private landowners engaged in production agriculture with longstanding roots in the community, as such it is believed that their experiences and understandings may best lend themselves to a wider audience within Grant County. The key interviews were numbers 9, 13, and 15. As the key interviews of this study, a disproportionate number of their quotes and perspective are represented in the results. Care was taken to ensure that all of the interviewee's voices were shared in this manuscript.

In summary, a series of 17 open-ended interviews were conducted to explore understandings of changing land use and land management practices among residents of Grant County, Oregon. The interviewees were identified using both purposive and snowball sampling techniques. The interviews were structured by the use of an interview guide (Appendix A). The interviews were audio recorded, manually transcribed, and then coded by the researcher for common themes. Data analysis was conducted using grounded theory, documented with the use of analytic memos and diagramming. The emergent themes and significant findings are presented in Chapter 4: Results. 


\section{Chapter 4: Results}

The interviews provided a wealth of qualitative information about changing land uses and land management practices, influences on decision making, and opportunities for the future in Grant County. The results begin with Part I: Social, Cultural, and Economic Change, which sets the stage by recounting the primary socio-economic and socio-cultural changes described by the research participants. The issues of community degradation, changing land ownership patterns, shifting public perception of ranchers, and increased cultural acceptance of conservation and general environmental awareness are each discussed.

Part II: Changes in Land Use and Land Management, includes interviewee’s descriptions of land management practices of the past and present day, including grazing, irrigation, logging, mining, conservation, restoration, weed management, and several new markets that present day private landowners are exploring to diversify their personal economic base. This section also includes data on current day decision making and constraints to natural resource management, primarily on private lands. The changes described in Parts I and II are summarized in Table 5 and illustrated in Figure 6.

The final section of the results, Part III: Significant Findings, summarizes the major themes that emerged from the interviews, such as a common desire for balance, the difference between preservation and conservation, and the importance of recognizing ranchers as stewards. This section also highlights opportunities for landowners, natural resource managers, restoration practitioners and residents in Grant County. 
The results are presented here qualitatively, framed only occasionally by the number of respondents or frequency with which a theme emerged. A quantitative depiction of the results was determined to be less informative than a qualitative description based upon the researcher's intimate knowledge of the data, the grounded theory process, and the qualitative methods used to collect the data. However, a quantitative breakdown of the results is provided in table format in Appendix E.

\begin{tabular}{|c|c|c|}
\hline $\begin{array}{c}\text { Socio-Economic } \\
\text { Changes }\end{array}$ & $\begin{array}{l}\text { Socio-Cultural } \\
\text { Changes }\end{array}$ & $\begin{array}{c}\text { Socio-Ecological } \\
\text { Changes }\end{array}$ \\
\hline $\begin{array}{l}\text {-Community degradation } \\
\text { - } \quad \text { Dwindling population } \\
\text { industry } \\
\text { - } \quad \text { High unemployment rate } \\
\text { Children leave to find } \\
\text { work } \\
\text {-Changing land ownerships } \\
\text { - } \quad \text { Fewer, larger ranches } \\
\text { - } \quad \text { Subdivision } \\
\text { - Sales to absentee } \\
\text { landowners, hobby } \\
\text { farmers, and } \\
\text { - } \quad \text { Leanservationists } \\
\text { grazing lands for } \\
\text {-Diversifying with New } \\
\text { Markets } \\
\text { - Fee hunting, ecotourism, } \\
\text { niche markets }\end{array}$ & $\begin{array}{l}\text {-Public Perception of } \\
\text { Ranchers } \\
\text { - Shift from the } \\
\text { "idealized cowboy” to } \\
\text { "environmental } \\
\text { villain” } \\
\text {-Increased Environmental } \\
\text { Awareness } \\
\text { - Recognition of need to } \\
\text { monitor water use, } \\
\text { rotate pastures, etc. } \\
\text {-Acceptance of } \\
\text { Conservation on the Middle } \\
\text { Fork } \\
\text { - Acknowledgement of } \\
\text { economic } \\
\text { contributions to the } \\
\text { community } \\
\text { Participation in } \\
\text { conservation activities } \\
\text { from most landowners }\end{array}$ & $\begin{array}{l}\text {-Improved condition of rivers and } \\
\text { rangelands } \\
\text { - } \quad \text { Improved grazing and } \\
\text { irrigation practices } \\
\text { - } \quad \text { Conservation and restoration } \\
\text { efforts such as conservation } \\
\text { easements, water rights } \\
\text { transfers, irrigation efficiency } \\
\text { projects, riparian fencing, } \\
\text { instream restoration projects, } \\
\text { juniper control and weed } \\
\text { management } \\
\text { - Significantly fewer mining } \\
\text { operations } \\
\text {-Worsening conditions in public } \\
\text { forests } \\
\text { - Continued fire suppression } \\
\text { - Not enough logging, forests } \\
\text { are choked } \\
\text { Decreased opportunities for } \\
\text { grazing on federal lands }\end{array}$ \\
\hline
\end{tabular}

Table 5: Summary of the Most Frequently Described Changes in Land Use and Land Management in Grant County. Socio-economic and socio-cultural changes are described in detail in Part I of Chapter 4: Results. Socio-ecological changes are described in detail in Part II of Chapter 4: Results. 


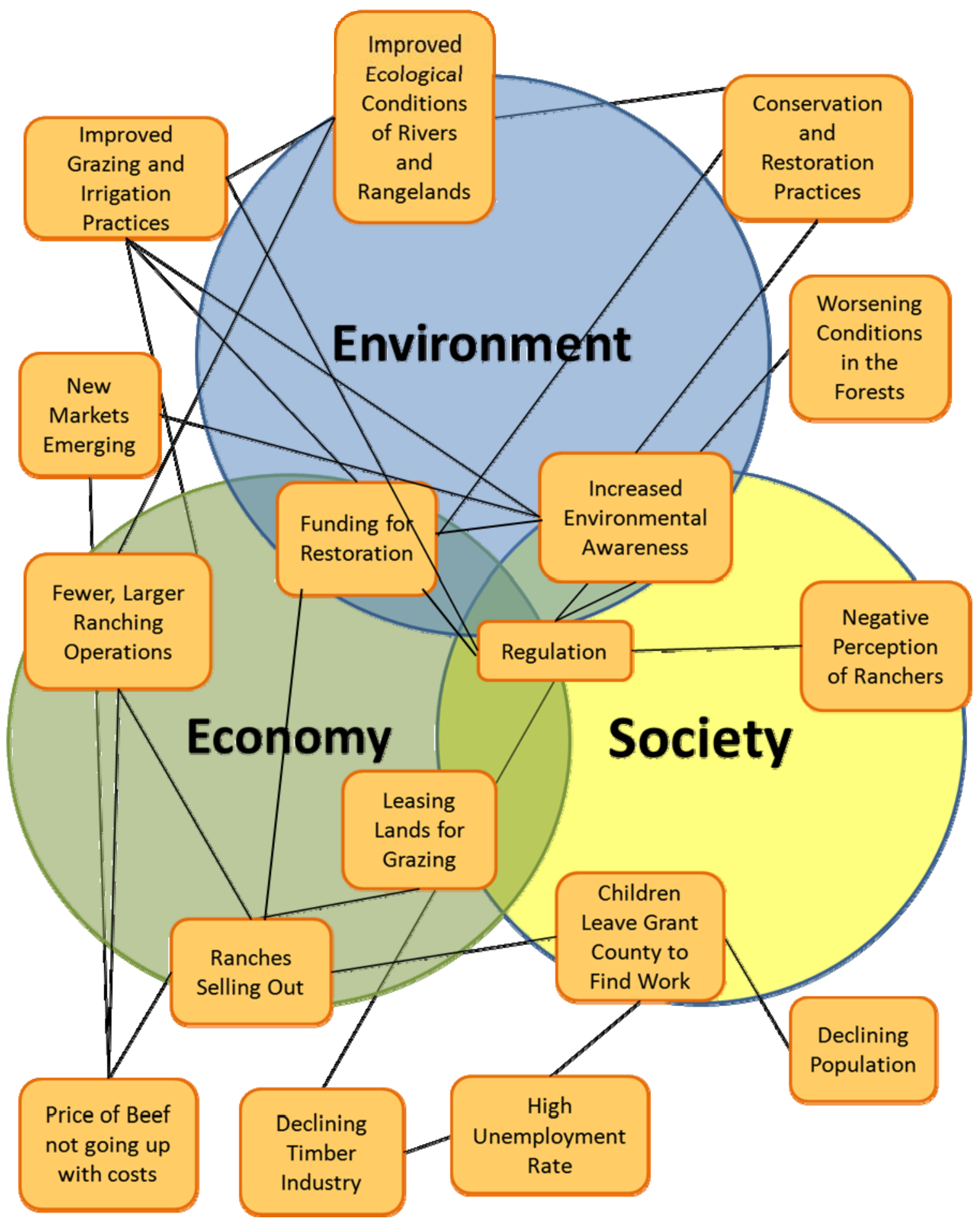

Figure 6: Concept Map Diagramming Some of the Most Significant Social, Economic, and Ecological Changes Affecting Land Use and Land Management in Grant County. Linkages are shown to illustrate how these changes are related to each other and what some of their effects are on the economy, environment, or community. 


\section{Part I: Social, Cultural, and Economic Change}

\section{Socio-economic Changes}

\section{Community degradation}

It was difficult to discuss changes in land use and land management in Grant County without also discussing changes in the community and economy. In many instances, people’s first response to questions about change was to describe how Grant County's schools, tax base, population, and employment opportunities have decreased through the years. They described these social and economic changes as a direct result of shifts in land use and land management.

Several of the ranchers who brought up the decline in their community as a major change began the discussion by recounting their grade school or high school classes and how few of their classmates were able to find work and raise families in Grant County. As one explained, “There's very little opportunity for the young families to survive in this area. Consequently our schools have went away- and that's pretty much the heart of any rural community. For example when I was in high school we had buses that would run in every direction out of town, 4 directions. And there were actually 6 buses, 2 feeder buses that fed the bigger buses. And there were very few kids that attended school that lived in town. It's kind of hard to imagine but the families were ranch families. And today it is just the opposite (Interview 13).”

The experiences of others echoed this same story. Another long time rancher explained that out of his father's 17 grandchildren, only one was able to stay in Grant County and ranch. Another landowner lamented, “There’s nothing more shameful than if 
Grant County has a hundred graduates, 90 to 95 of them have to leave Grant County to earn a living (Interview 10).”

Those interviewed identified a few different drivers of this change. There was near unanimity that the lack of logging jobs is largely to blame, "As far as changes in the valley, it's all about the timber industry. These little towns in Eastern Oregon are dying. And they're dying because we had really good high wage paying jobs for young families when the timber industry was still going (Interview 15).” Others point towards a natural progression in rural landscapes across the country towards breaking up large tracts of land among multiple owners and of the population shifting towards the cities where there are more jobs. Some also pointed towards the preponderance of absentee landowners and retirees without children as a reason why the schools are emptying out.

Whatever the reasons, Grant County's socio-economic demographics are shifting and long time community members are well aware of the change. A natural resource manager who works throughout the county brought up a pertinent point for other managers to consider in their planning and coordinating efforts, "We kind of lose track of the fact that people are part of that environment too. And we need to consider what's good for people in a healthy economy and what goes with that- community, schools, all of that (Interview 4).” When issues like community resilience and sustainability are explored later in this chapter, this approach will be key. The emergence of sustainability as a common thread in the interviews is further discussed in Part III: Significant Findings. 


\section{Changing Land Ownership Patterns}

The most common change described by private landowners was the reduced economic viability of cattle production in Grant County and subsequent effects on land ownership, the community, and natural resource management. As one long time Grant County resident explained, "You used to be able to make a living for your family with what we called a '150 cattle outfit.' With 150 cows and calves you could take care of your family, and now that's way out. I think most people that have 500 cows nowadays they think they're scraping by. If you get to be between 750-1000 then you might be more comfortable. Most of those won't say that because it's still a battle to have the huge investment in land and machinery and buildings and then try to pay that when the cost of your product hasn't gone up as high as the cost of your inputs (Interview 12).” Other changes, including fewer working ranches, subdivisions, and sale to absentee landowners and conservation-oriented organizations was linked to this altered economic situation in the ranching business.

Shifts in land ownership patterns were linked directly to the altered economic situation in the ranching business. As a resource manager from a long time ranching family explained, "Subdivision has been happening. Lots of ranches have been broken up. Not so much because of impacts from environmental concerns but mostly from the economics of cattle production (Interview 4)." Sale of ranch land to absentee owners, hobby farmers, conservationists, and others was described with some regret by the longtime private landowners. As one put it, "I may end up selling something. It makes sense. The easy way out would be to sell this piece. Because I could sell it for a profit in 
a heart beat. And I'd still have the rest. But God, I don't want to be me if I sold this to The Nature Conservancy or the Tribes and people are all just watching me.... I tell them, you know, I may have no choice (Interview 9).”

The sale of land to conservation groups, the Tribes, and the government was identified as a change predominantly along the Upper Middle Fork where the Intensively Monitored Watershed (IMW) is located. As another long time ranching family from the Middle Fork put it, “The conversion of private land to government owned land is a real concern. And there's hardly any cattle left running on the Middle Fork now.... We're losing grazing possibilities and private ownership and those tax dollars and at some point we have to be able to support ourselves. The government can't keep continuing to dole out money to non profits to do anything (Interview 6/7).” This final point about the sustainability of buying up private land for conservation purposes is discussed further in the sustainability section in Part III of these results.

Outside of the IMW, conservationists buying up land was not reported as a major change or concern. In other areas absentee ownership and conversion to "ranchettes" were described as more frequent outcomes of ranch subdivision. In a few cases purchase of subdivided lands by fellow ranchers was described as an outcome. The ranching operations in Grant County were described by the ranchers interviewed as fewer and larger nowadays. "I know there used to be a family owned every 320 or 640 acres in this country. And mostly through economic hardships have sold out to bigger ones.” He went on to explain "It's been good in a lot of ways for the landscape. These 12 families 
that I was talking about over here 40 years ago probably had more cattle than their land would support (Interview 13).”

The growing number of absentee landowners, hobby farmers, conservationists, and other who do not manage their own land for production agriculture provide ranchers with opportunities to utilize land they don't have to own outright. "I lease a lot of land from absentee owners. It gives me the ability to move my cows around and rotate pastures and give pastures the rest that they need (Interview 13)." Almost all of the private landowners interviewed either lease their land to others or lease land from others as part of their business model.

\section{$\underline{\text { New Markets }}$}

Six of the private landowners interviewed identified new markets, boutique industries, and "unconventional” ways in which they're diversifying their economy so that they are not solely dependent upon ranching or logging. As one Middle Fork landowner explained his mix of undertakings, "We raise cattle. The diversification would be a lot of years, when the timber prices are good, just to manage the timber I would log certain sections for a diversification. The other thing that I've finally relented and started this year is fee hunting (Interview 9).”

Fee hunting appears to be a recreational use which private landowners can market to make a profit and share some of what they love about the countryside. It appears to be a potentially fruitful profit stream for landowners who qualify for hunting tags from Oregon Department of Fish and Wildlife to kill nuisance predators or grazers on their land. Some landowners are selling those tags as hunting rights to individuals looking to 
experience hunting in Eastern Oregon. As another private rancher explained, “We do quite a bit of guided hunting.... What we've done now is we've leased our hunting rights out to a large corporation and then they have a guide that guides it. We used to, well I was guiding for 35 days or more a year and it just got too much for my wife to have to do all the other work (Interview 10)."

Tapping into ecotourism and the hospitality industry has also been a fruitful venture for a couple of the landowners interviewed. One of the Grant County ranching families runs a bed and breakfast out of an old school house on their property. One Middle Fork resident runs a cabin-stay and offers horse rides in addition to hobby farming and working another job remotely. As he explains it, "I can certainly develop a third leg of my economy off of this property. With tourism, the horse rides, the cows, you know, 5 cows, I can make a little money when I sell them to folks (Interview 5).”

One Grant County rancher described private consulting for a well to do transplant to the area as a side business he engages in. Given the increasing prevalence of absentee landowners and hobby farmers with land, and the decreasing profit margins being made by traditional and long time ranchers, professional ranch consulting services may become increasingly important.

Another niche market mentioned was selling beef to the sustainable, "local-vore," high end beef markets through cooperatives such as Country Natural Beef, which started out in eastern Oregon. At least one rancher interviewed raises his cattle for this market. Others agreed that there is a growing market for this type of beef. As one long time rancher from Grant County mused, "I think the future is that people like us are going to 
be the forefront of the industry because everyone wants a piece of this. Everybody wants their beef coming off a place like mine. They want to know who raised it, how it was raised, was it abused? So we're that guy (Interview 15)."

\section{Socio-cultural Changes}

\section{Public Perception of Ranchers}

Four of the Grant County ranchers interviewed described a change in the general public’s perception of ranchers in Eastern Oregon. Two private landowners from long time ranching families described it as a shift from a romanticized ideal of the western cowboy to the current conception of environmental villains. "It used to be that the American people, the American society, everyone was kind of enamored with the western culture- our way of life, the rugged individualism, these guys out here banging away trying to make a living ranching. But there's been a real change in that, especially in the state of Oregon (Interview 15)."

Another private landowner and longtime rancher explained the changing societal perspective on ranchers another way: “We've had two generations now that have been educated in our public schools that ranchers and loggers are bad people, they're bad for the environment. They're bad for everybody. I don't know where those people think their food comes from or where they get their shelter (Interview 13).” Political polarization in the state of Oregon, the Endangered Species Act conflicts with both logging and grazing, and prioritizing the environment above other societal factors were all described as being linked to this shifting perception of ranchers. 
One private landowner interviewed offered a positive outlook on the future of this adversarial view of ranchers, "I actually think that it's getting better.... That maybe ranchers are maybe not as bad as everybody thought we were. We are kind of the last holders of free ground. Maybe join forces with them and try to get along with them and we might have a little more success with conserving the environment and these riparian areas. And maybe we ought to go after developers and other people who are going after free ground (Interview 8)." Most of the conservation-oriented land managers interviewed seem to be in agreement with this concept of "joining forces" and avoiding the polarized argument of the western rancher versus the staunch environmentalist.

\section{Cultural Acceptance of Conservation on the Middle Fork}

Within the IMW on the Middle Fork, the public land managers and private, conservation-oriented landowners described an evolving “cultural acceptance” of conservation, restoration, and salmon-focused management interests. "They were pretty reactionary in the beginning, but then people saw "Oh, there's money to be had here and it's actually benefiting the community (Interview 17).” Another land manager explained, "There were a lot of people when I first moved up there who were like, "Oh, are the Tribes buying up all the land?" There was this concern because they had just purchased the Oxbow in 2001 and the Forrest Property in 2002 and I think the county just sort of thought there was this mass buy up of land. And they saw the Tribes as something of a threat. But I think now we've kind of evolved, where I think they see the Tribes bring a lot of money into the community (Interview 16).” Though some of the private landowners interviewed continue to express some concern about future land sales to conservation 
oriented groups, it seems that from the perspective of the conservation-oriented groups the skepticism has lessened considerably over the past decade.

All of the Middle Fork landowners interviewed practice one or more conservation-oriented management technique. As one of the Middle Fork landowners described, "When you look at the Middle Fork today from the headwaters down to us I think every piece of property, except Forest Service, is in some sort of contributing water through water rights or the Tribes are managing it or... a lot of people would've said there is no possible way that's going to happen in Grant County (Interview 17)." A variety of techniques are being used to meet conservation goals and improve land management on the restoration-focused Middle Fork. Current land management techniques are described in further detail in Part III.

A relatively new private landowner on the Middle Fork remarked on the cultural acceptance of restoration on the Middle Fork in further detail. As he explained, "As far as the whole Middle Fork area I think you're definitely seeing the focus and infusion of all these restoration dollars... The long term folks remain for the most part very doubtful, very skeptical, if not downright critical of the restoration work. There are two ways that attitude exists, I think. Number one because they've been here so long it's the traditional 'this is the way it's always been and why are we gonna screw with it?.' Secondly, I don't think people out here who are involved in these projects have done a very good job of bringing along the folks to explain (Interview 5).” 


\section{Continued Resistance to Conservation}

Some interviewees expressed dissenting views on the usefulness, need for, and logic of restoration. Though this study intentionally focused on landowners within the IMW and elsewhere in the County who are already engaged in conservation-oriented activities, two interviews were conducted with Middle Fork residents who do not own or manage land. One of these residents had a particularly unique perspective on changing land use and land management in Grant County as she was the oldest community member interviewed and could remember first hand logging's "heyday" in the first part of the last century. Her views likely reflect those of the "long term folks" referenced in the preceding excerpt.

This respondent expressed dissatisfaction and frustration with current land ownerships and land management techniques along the Middle Fork. When asked about what changes she had observed in her eight decades in Grant County and long time residence along the Middle Fork, she replied, “They won’t even let you get on their land. And you used to be able to just enjoy it, but you can't even enjoy it anymore. And it looks terrible. And I don't know, it just isn't like it used to be. I've seen the best of her (Interview 3).” She also described with regret the logging shutdown, job loss, the fact that they have stopped stocking the river with fish for recreational purposes, and the buy up of land by The Nature Conservancy and the Tribes.

It is important to note that the views expressed by this interviewee may be representative of others like her in the community and as such may provide an important contrast to opinions and experiences shared by the rest of the population sampled. Since 
this study is focused on the Middle Fork and on individuals already engaged in conservation-oriented activities, her responses are in the minority of this group. Increasing Environmental Awareness in Grant County

Elsewhere in the county, outside of the IMW, a general sense of increased environmental awareness and changing resource management practices has also been observed. As a conservation-oriented Middle Fork resident explained, “The environmental community here is relatively low in population but the Grant County people do acknowledge that there is an environmental question. Even if they don't like what's going on with the salmon....They acknowledge that's something real going on there (Interview 1).” Another natural resource manager who works throughout the county explained that he's seen “lots of change from people focused on production agriculture to more interest in how things look. Most of those people are interested in conservation aspects, they don't mind giving up some production area for the benefit of fish and wildlife, water quality, that type of thing. (Interview 4).” This last perspective probably relates to hobby farmers and absentee owners more so than to those still engaged in production agriculture.

A private landowner who owns property on the Middle Fork and elsewhere in the county provided some detailed examples of how this increased environmental awareness manifests itself among ranchers in terms of water usage and grazing practices, "And the change has been to now people are pretty well aware that they must have a (water) measuring device, they can't take more than their right calls for, and if they've got water they'd better take care of it. And that again changes the way that you manage the land. I 
think we've seen, when I was a kid you'd say 'ok, this whole place will run 200 pair.' So you'd take them and you'd put them there. You'd turn them out in the spring when they were done feeding and the grass was tall enough and you didn't get them in until fall. You didn't look at them. They would stay there for 5 months. But now we pretty much rotate pastures. It's more efficient. Calves grow better. It's more productive. So not only are you taking better care of your irrigation water but you're trying to get more out of your pastures (Interview 9).” The way that individual practices like irrigation and pasture rotation are changing is further described Part II and III of these results. 


\section{Part II: Socio-Ecological Change: Land Use and Land Management Then and Now}

\section{Land Management Practices of the Past}

All of the Middle Fork and Grant County residents interviewed described changes in land management practices witnessed during their lifetimes or years of residence. From the private rancher's perspective, one individual framed it in terms of survival: "Well, a lot of it is just purely economics. Because ranching is a tough business. Your profit margins are not always very good. So survival necessitates change (Interview 9).” When asked whether their practices had changed in the relatively short period of time that a conservation organization had been managing land on the Middle Fork, one of their employees explained “Well, yeah, they're probably always changing as more information comes (Interview 1).” Change is inherent to land management and the individuals interviewed provided no shortage of information on how they had seen mining, logging, grazing, irrigation, and other practices change over time.

\section{Grazing}

Every participant described grazing as a past land use on their property and on the lands around them. Even on properties that were not actively managed for grazing, trespass grazing was described as common. In describing previous grazing practices, ranchers and conservationists alike explain that there were more cattle on private and federal lands, less management of where they were and at what times of year, and that overall the historic management practices were more harmful to the environment than 
current practices. All respondents described the land they currently own as having been in worse shape in the past.

The following comment from an individual from a long time ranching family exhibits some of the shifts in rangeland management that he has witnessed in his lifetime, "We'd be the first to admit that a lot of the management 30, 40, 50 years ago might have been a little destructive. But people didn't know better. They would run the riparian areas 365 days a year...when we first started running riparian areas the riparian areas were recognized as sacrifice areas because they were such a small portion of the total countryside. You managed for the uplands (Interview 10).”

While cattle have remained the predominant type of livestock in Grant County, two longtime residents recounted sheep and horses each as having been present on the landscape in large numbers historically. It was also noted that from the early homesteads to as recently as the mid twentieth century, most individual households raised not only cattle but other livestock and small animals for personal use. "Everybody at the time did a little bit of subsistence- large gardens, milk cows, chickens. That's a major difference. Nobody uses a milk cow anymore (Interview 12).”

\section{$\underline{\text { Irrigation }}$}

Irrigation of hay fields has always gone hand in hand with grazing. For the most part, lands used for grazing were also used for growing hay and if water was available these fields were irrigated. Water rights are an important issue in Grant County, where water shortages are a problem in the dry summers. Eleven of the individuals interviewed maintain water rights, some from as far back as the 1860s. During the past 150 years, 
how individuals use their water rights has changed. In many cases, significant projects like stream relocation or the construction of irrigation ditches were undertaken in order to improve hay fields or improve access to water. On the Middle Fork, some of the restoration projects implemented in the past few years have been targeted at restoring sections of stream where these activities took place.

One of these stream relocation projects which was recently undone by a large scale restoration project on the Middle Fork, actually won the previous landowner a "Farmer of the Year" award. As one of the landowners involved in the recent restoration project tells it, "Some people think this is pretty funny- Phil Murphy in 1951 or 52 was awarded the Farmer of the Year for the work that he did to basically channelize the river. And there's some people that think it's pretty ironic that today we're basically trying to undo the work that he got this award for (Interview 17)."

Irrigation practices themselves have also changed over time. As one landowner explained, "They were irrigating for hay but then nobody was turning it off. It was an uncontrolled system. The water master never came and enforced the season. And it was pretty much not fish friendly to any degree of what we would consider fish friendly today (Interview 16).” While measuring devices, watering seasons, and regulation are more common today, the interview participants confirmed that historically private landowners used their water rights at their own discretion with little regard to fish or other instream water needs.

These same practices could also be found on federal lands in the past. The Forest Service owns many of the water rights on their lands. As the Forest Service employee 
interviewed explained, the Forest Service and their permittees have a long history of developing these water rights to enhance grazing opportunities on federal lands. There are also many water rights that predate the creation of the Forest Service in 1909. In some cases, irrigation diversions on public lands serve to transfer water to private lands. Channel relocation, diversion ditches, and irrigated hay fields were all practiced on federal lands for many years.

Logging

The decline of the timber industry is a major driving factor of change in the socioeconomic conditions in Grant County. In the late 1800s, logging quickly became the dominant industry of Grant County as the viability of the mining industry waned. Up until the 1990s logging was the mainstay of Grant County’s economy. It is challenging to separate many of the changes in land use and land management that interviewees describe from the overarching issues of the timber industry in their community. Those changes are described in further detail in Part I: Social, Cultural, and Economic Change.

The logging and timber industries have undergone significant change during the lifetimes of those interviewed. As a lifelong community member recounted, “There's one mill in John Day. And there used to be a mill in Bates. And between John Day and Prairie (City) there were three or four more. And the men had jobs. Nobody works now (Interview 3).” Multiple individuals interviewed recounted this same observation of mills closing one by one, and expressed fear that the last remaining mill in Grant County may not be able to survive the recent recession. 
It was reported that much of the logging that occurred in Grant County took place on Forest Service land, with profits benefiting those employed as loggers, those employed at the mills, the Forest Service itself, and the community at large. As a longtime community member explained, “...64\% of Grant County is public....They don't pay taxes. So the only income we ever got off that land was timber. And then that timber was split by congressional delegation between our schools and our roads. Period. That's all it went to. (Interview 15).” One of the private landowners interviewed who manages rangelands as well as timber resources reflected, "Region 6 of the Forest Service used to cut enough timber to finance the entire Forest Service for the entire nation and have money left over (Interview 14).” Region 6 of the Forest Service includes all of Oregon and Washington.

The Forest Service employee interviewed described how the Forest Service's motto, “Caring for the land and serving people," has played out over time. "The whole emphasis for the Forest Service was for multiple use, not any one single use. Maybe not multiple uses everywhere, but in that concept. Originally it was very timber driven, timber dominated. Then in the 70's we started to switch, even though it was still very timber-driven, you started to see a switch to recreation (Interview 11).”

Most landowners on the Middle Fork and elsewhere in Grant County describe their property as having been logged in the past, sometime multiple times. "It was always in conjunction. Logging always took place, wherever there was timber (Interview 10),” noted one private landowner who still harvests timber from his land when and where possible. 
When logging was discussed, the conversation focused mainly upon the practice as a whole, without any detailed discussion of techniques. One individual interviewed recounted the original horse-powered logging crews. A couple people referred to the short period of clearcutting that occurred on federal land. None of the individuals interviewed mentioned the many associated splash dams, mills ponds, or other riverdependent logging techniques that were used. Other than sedimentation, the only other river effect described was that of removing all the wood from a stream after the area around it had been logged. As one natural resource manager explained, “The science of the day was after you get done with a timber sale you go through and remove all the large wood out of that creek. That was just common practice (Interview 4).”

\section{Mining}

Mining for gold was the activity that initially drew prospectors and eventually settlers to Eastern Oregon. The Forest Service described mining as “fairly huge, especially in the Middle Fork (Interview 11).” Only Middle Fork landowners described mining as a past land use on their property. Where gold was found the landscape was altered heavily. Only a couple of the Middle Fork landowners described mining as a past land use on their property, since gold was only found in a few areas.

\section{Change in Condition of the Resource}

There appears to be general agreement among private and public landowners along the Middle Fork and throughout Grant County that the rivers, ranch lands, and fish and wildlife populations are in better condition now than they have been in the past 20, 50, or 100 years. The same could not be said for the public forests, which were generally 
described as overstocked and lacking in appropriate management. Opinions on forest health, the logging industry, and the Forest Service are described further in Part III in the section of current forest management practices. Non forest conditions, however, were generally described in the interviews as being in better condition today than they have been in a long time, as the following summary depicts.

Along the Middle Fork several private landowners and public land managers described the change in vegetation along the river and its tributaries. "A lot of the properties we own looked like golf courses. We have photos that show that there wasn't any riparian vegetation there. And now you're seeing this transformation happen (Interview 16)." When I asked a private resident along the Middle Fork about change she has witnessed in her few decades there, she immediately described the riparian areas "Well, first of all when we first started moving here there were hardly any willows or anything along that river (Interview 2).”

As far as the rangelands are concerned, most of the individuals interviewed remarked on their improving condition throughout the county. A private landowner and long time member of the community mentioned, "I've seen a big change in the landowners in the last 20 to 30 years. I think they manage the land a lot better. They don't overpasture as bad as some of their predecessors did (Interview 9)." Private and public landowners committed to managing for fish habitat along the Middle Fork ascribe much of the change to improved management, fewer cattle, and recent ecological restoration projects. As one relatively new private landowner explained, "In our place we have forced significant change (Interview 5)." 
Private landowners from elsewhere in the County also report improved ecological conditions, though they are reluctant to denounce previous land management practices and are careful to avoid criticizing previous private landowners or their practices. Two private landowners from long time ranching families expressed this sentiment, articulated well by these words from one of them, "They did the best they could with the knowledge that they had but they simply abused the land. And the only way they could make a living was off the land. I hate to say it, so it's not taken out of context somewhere, but in that respect for the resources, the evolution of bigger ranches compared to smaller, overstocked ones has been a good thing (Interview 13)." This statement was made with a significant level of regret, as the individual went on to explain how many negative effects the shift from small to large ranches has had on other components of his community.

\section{Current Land Management Practices}

\section{Current Grazing Practices}

A variety of different practices were described by the public and private landowners interviewed who currently manage for cattle grazing. Of the 15 interviewees who own or manage land, only one conservation-oriented land manager from the Middle Fork completely prohibits grazing on their land. Of the other conservation-oriented landowners on the Middle Fork, each has their own strategy or reasoning behind the limited grazing they do allow. The Warm Springs lease grazing pastures on their Oxbow and Forrest properties, partly "to show that ranchers can do the types of activities that we're trying to foster and demonstrate that this type of activity will work to create some 
crops and do some revenue-generating agricultural activities and you can protect these fish habitats (Interview 16).”

Another private conservation-oriented landowner expressed a similar sentiment of wanting to try to blend income-generating and conservation-oriented activities with a limited number of cows on his land. Yet another conservation-oriented landowner on the Middle Fork described his use of cattle for management purposes, such as weed control, and limited the lands he leased for grazing to upland habitats that have been grazed before.

Current grazing practices described include rest rotations, deferred rotations, season-long grazing, seasonal grazing, winter permits, and numerous different leasing options, including use of federal grazing allotments. As one landowner explained "There's a lot of opportunities to raise cattle and not have to own as much base property (Interview 14)" as compared to the ranches of previous generations. The prevalence of leasing land from absentee landowners was also described in Part I of these results under changing landownerships.

\section{Federal Grazing Allotments}

There continues to be a significant reliance on federal grazing allotments by private ranchers. Ranchers see these federal grazing allotments as essential to their cattle raising operations and also essential to the health of the whole watershed. As one interviewee explained, "The Forest Service allotments in this area are critical to sustainable, viable ranches. Most of the ranches are in the lowlands that really shouldn't have a cow on them in the summer months. Then we have this fantastic resource up here 
in the mountains that is perfect forage for livestock in the summer time. And the ranches that have the ability or have Forest allotments are just about across the board in a better condition than the ones that don't. If you take that out of our ranches today you'd see some serious degradation on private lands (Interview 13)."

An important historical perspective on federal grazing allotments was brought up by one lifelong rancher from Grant County. In describing the importance of Forest Service allotments to private operations he explained that each allotment is based on a longstanding agreement developed between a private property owner and the Forest Service at the time of the Taylor Grazing Act of 1934 (though many of these same families were grazing the same lands prior to 1934 without any regulation). While the grazing permits are good for 10 years, they have usually been renewed year after year with the same person or family. "So those have been set in stone all my life. Those numbers don't go up and down. That's been a constant number all my life. So we're still grazing the same places that these ranches grazed for well over a hundred years. (Interview 15).” As this quote reveals, private property owners have come to depend on being able to lease federal allotments as a key component of their business model. In many cases land swaps and acquisitions have taken place so that a family's private lands are located adjacent to their federal grazing allotments. In some cases the ongoing litigation on federal grazing allotments is affecting landowners who have participated in such land swaps and strategic acquisitions.

\section{Fencing}


Each of the conservation oriented landowners on the Middle Fork fence cows out of their riparian areas; some of them have enrolled the land in conservation easements with the Natural Resource Conservation Services' (NRCS) Conservation Reserve Enhancement Program (CREP) or Bonneville Power Administration. Most of the private, production agriculture-oriented landowners on the Middle Fork and elsewhere in Grant County also fence the riparian areas of their properties to exclude cattle. They too take advantage of program like CREP, Oregon Department of Fish and Wildlife’s (ODFW) John Day Habitat Enhancement Program, and others.

In addition to benefiting the fish by keeping cows out of the stream and riparian areas, the fencing programs also help ranchers manage their cattle. As one Grant County rancher who is not a proponent of cattle exclusions for riparian recovery mentioned, "Cattle have to be managed. You can't just turn them out and expect them to take care of their selves or the land, because both bought in a hurry.... I have fenced some riparian areas simply because it allows me to manage my cows. I've found it's pretty tough to manage cows without fences (Interview 13).”

While the previous landowner quoted is not a proponent of exclusions, he does support fencing riparian areas and claims to have been one of the first in Grant County to fence critical steelhead habitat. But he contends that the fenced areas can be managed to sometimes have cattle in them and other times keep them out. Two other private landowners, one who owns land on the Middle Fork and another who leases land on the Middle Fork, expressed being opposed to the concept of riparian fencing altogether. Current Irrigation Practices 
Water rights are an important and contentious issue in Grant County. Many of the landowners interviewed retain original water rights from the homesteads that their families or others carved out of the landscape in the late 1800s. Every one of the landowners interviewed has been involved in some sort of irrigation project with the Soil and Water Conservation District or the Freshwater Trust. Irrigation projects include things like installing fish screens to keep fish out of irrigation ditches. Constructing return flow cooling systems to cool water used for irrigation or installing infiltration galleries or pump and pipe systems are used to enhance water quality and improve upon the flood irrigation systems still used by many landowners. Leasing, selling, and turning in water rights for in-stream uses is becoming a common practice on the Middle Fork.

While many of the conservation oriented landowners have returned some of their water rights to in-stream uses, only one landowner, The Nature Conservancy, has ceased irrigating entirely. The Warm Springs, the Forest Service, and the two private landowners who manage for conservation on the Middle Fork all maintain some water rights and use them frequently enough to keep them (every five years). Just one of the private landowners interviewed has engaged in a water rights deal, and it is only a partial season lease. A few of the private landowners interviewed are quite skeptical of the efficacy and logic of in-stream water rights usage and are concerned that the practice is not producing more in-stream flows and may be lowering the water table.

When asked about what concerns them about land and water issues in Grant County, the most common response received was water quantity. This issue was brought up by 5 interview participants, including both conservation-oriented and agriculture- 
oriented managers. The overallocation of water rights and the lack of oversight of water use were mentioned as concerns about current and future irrigation practices. Concern over the effects of prescribed burns and other practices that affect freshwater springs and snowmelt patterns was also mentioned.

The John Day Basin is well known for being one of the only major river systems in the United States without a dam. Though many conservationists pride themselves upon that point, one private landowner suggested that the lack of water storage may be a problem down the road. He pointed towards large creeks with little habitat that could easily be mitigated for and suggested that damming a stream and being able to supplement flows for irrigation and in-stream uses during the dry summer months could be a real opportunity for ranchers and conservationists in the future.

\section{Conservation and Restoration}

Every landowner interviewed has been involved in some sort of conservationoriented project, whether it be stream fencing, tree planting, installing a check dam, or implementing a full stream reconstruction project. Most forms of restoration being practiced in Grant County today are integrated into existing management strategies. Stream fencing is employed not only to protect the stream, but also to help manage cattle in different pastures. Return flow cooling systems, piped irrigation, and diversion screening serve not only to improve water quality and conserve water quantity, but also to make rancher's day to day lives more efficient. In many cases check dams are built or stream banks are planted as much for stabilizing an individual's land as for reducing 
sediment inputs into the water. These mutual benefits are discussed in further detail in the following section of this paper on decision making.

Relatively few restoration or conservation projects are implemented purely for the sake of conservation. Those types of projects are generally the most extensive restoration projects and they have been implemented by conservation-oriented public and private landowners on the Middle Fork of the John Day River. Five of the eight landowners interviewed on the Middle Fork have been involved in channel reconstruction or remeandering projects purely for the purpose of restoring salmon habitat. Those same landowners have implemented other fish-focused projects like removing mine tailings from their stream banks and adding large woody debris to the stream. None of the private landowners focused primarily on production agriculture described being involved in projects like these.

Another form of conservation that public and private landowners describe being involved in is easements. Conservation easements provide a source of income to the landowner while conserving the land put in easement for a length of time specified in the agreement; in some cases in perpetuity. Four of the Middle Fork landowners described some or all of their land as being held in an easement.

The restrictions placed on land uses and activities under an easement vary from case to case. Only one easement on the Middle Fork precludes grazing on an entire property. Most riparian easements do not allow grazing along the stream, though the Warm Springs' easement with BPA on the Forrest and Oxbow Conservation areas allows for riparian grazing, though they don’t yet practice riparian grazing on the property. 
Of the four Middle Fork landowners with conservation easements on some or all of their property, two of them have land enrolled in the Natural Resource Conservation Service’s (NRCS) Conservation Reserve Enhancement Program (CREP). Though none of the Grant County landowners interviewed identified CREP specifically as a program they participate it, it is suspected that some of the fencing programs they referred to vaguely may be CREP.

\section{Mining}

Few landowners described current mining practices. One Middle Fork landowner described a gravel mine on his property as providing a source of income for his family. Another Middle Fork landowner described an old gravel pit on his organization's newly acquired property. Though they don't actively manage the pit, they do intend to use some of the gravel for trade or profit to support restoration activities occurring in the watershed. Two other Grant County landowners interviewed explained that they had mining claims but had never really followed up on them. Both cited not quite having the “mining bug” or "gold fever” strong enough to follow up on the right to mine.

The Forest Service employee interviewed mentioned some recreational mining that still takes place on the Middle Fork. He also confirmed there are a few remaining patented claims for suction dredging on the Middle Fork, but that they are not being actively pursued at this time. He suggested this may be a point of future litigation since the State of Oregon has banned suction dredging on wild and scenic rivers.

\section{Forest Management}

Forest management on public lands continues to be an issue of contention. 
Discussion of current forest management practices elicited varied and opinionated perspectives. As was described earlier in the results, the decline of the logging industry in Grant County had numerous social and economic impacts. The majority of that was the result of a decrease in logging on public lands. Multiple of the production agriculture-oriented individuals interviewed were highly critical of the Forest Service’s current management techniques. As one of the private landowners who manages private timber lands described the National Forest's management, he said, “They've reduced the amount of logging on this forest, or timber management at all, to where the uplands are choked with timber (Interview 14).” The Forest Service was also criticized for employing prescribed burns under questionable circumstances, suppressing fires to a detrimental extent, and not controlling pest infestations that then impact neighboring private lands.

The use of fire for forest management was brought up by several individuals. As was just described, the Forest Service's prescribed burns have been critiqued as the following excerpt reflect, "Prescribed burn has its place. But what I'm seeing done is it's a source of income for the Forest Service to get paid so much an acre for the acres they treat....If conditions aren't right they still burn to get those acres. And that's not the way it ought to be (Interview 6/7)." Meanwhile, another respondent freely admitted he would like to see more periodic prescribed burns across the landscape on private and public lands to prevent catastrophic wildfires. One respondent expressed worry over how reduced grazing will increase the amount of forage and fuel for fires on the landscape in the already fragile forests. 
As the Forest Service employee described it, the Malheur National Forest's top three programs are Timber, Fuels, and Range. They are currently involved in litigation over grazing on federal allotments. The current lawsuit on this issue has polarized the community by posing rural livelihoods against the environment, a common theme in Gran County’s recent natural resource management history. The decline of the logging industry was closely tied to the listing of the spotted owl under the Endangered Species Act, so the current day issues with grazing and listed salmon appear to conger up similar defenses.

As the Forest Service employee interviewed described, "I personally believe that what is occurring here with livestock grazing is the same thing that occurred in the early '90s with the timber industry on the west side. Basically, due to things like ESA, Clean water Act, things are different. Things aren't the same. And it's real hard to get folks to invoke change. And at some point I think if we're not proactive and do that then we'll see some of the same results that occurred during that big push in the early 90's with the timber industry. I think that you could easily see livestock grazing come into a cease and desist, at least on public lands temporarily (Interview 11).” He went on to describe litigation as the primary driver of the logging shutdown that occurred and warned that the current lawsuits involving grazing allotments on federal lands might end with the same results.

Managing forests for timber harvest continues to be part of many private landowner's management strategies. Three of the private landowners interviewed continue to log portions of their land as the forests and the markets allow. Each of the private 
landowners interviewed who harvest timber from their land also described prescribed burns and thinning and part of their management strategy. One additional forest management strategy that was mentioned by just one landowner interviewed, The Nature Conservancy, was the restoration and protection of aspen groves.

Juniper Removal

The issue of juniper encroachment and the need for juniper management is prevalent throughout much of Grant County. Since the early days of fire suppression, juniper coverage on the landscape has increased dramatically. Juniper are native to the area but are considered a problem for watershed health because they draw large volumes of water from springs and streams. Most of the private landowners interviewed mentioned manual juniper control as one of their land management practices.

One private landowner from the Middle Fork explained that while he appreciates the fact that there are several programs to provide financial assistance to landowners who want help removing juniper from the land, he doesn’t support funding that sort of work because it doesn't get to the root of the problem- “There's only one feasible way to handle juniper and that's fire (Interview 9)." Unless fire is returned to the system, juniper simply grow back. Several landowners described their parents and grandparents as having cleared juniper form the very same land where they now remove 30' tall juniper trees.

The Forest Service was the only conservation-oriented landowner who described juniper removal as a component of their land management strategy. This is due to the fact that juniper grows in the uplands while most of the conservation-oriented 
landowners' land is in the lowland meadow ecosystem along the Middle Fork of the John Day River.

\section{$\underline{\text { Weed Management }}$}

Ten of the land managers interviewed identified noxious weed management as a component of their management practices. The Nature Conservancy was the only landowner identified that mentioned weed management as one of their top priority management activities. All of the landowners interviewed described it as an important issue in the county.

A variety of methods for weed treatment were described. Spot spraying with herbicides was described as the most common treatment method by conservation- and agriculture-oriented landowners alike. Grazing by cattle was also acknowledged as a useful mechanism for controlling invasive vegetation. The landowners without actively grazed lands described weeds as a worse problem than those that do actively graze. A few landowners also described goats, underburning, manual removal (pulling, cutting, etc.), and replanting with native plants as methods of weed control.

The Forest Service is the only landowner interviewed that does not use herbicides at all for weed treatment. As a federal agency the Forest Service must comply with the National Environmental Policy Act and analyze the potential effects of any activity they undertake. The Malheur District is in the process of developing an environmental impact statement for invasive vegetation treatment, which would allow for herbicide use. Until they complete that analysis they are limited to manual removal as their only weed management technique. 
The need for leadership and cooperation on weed management issues in Grant County was brought up time and time again. A couple landowners lamented the fact that Grant County does not have an active weed district. Many of the private landowners interviewed receive assistance with their weed management from the Grant County Soil and Water Conservation District.

Both the Warm Springs and the Forest Service described being criticized by the public for not doing enough to address weeds on their property. The need for cooperation in weed management across landownerships was voiced by numerous people. A private landowner who leases land on the Middle Fork and owns land throughout the County expressed frustration on the subject, "We have eradicated a few of the weeds on our place. The problem is the National Forest has them coming onto you constantly. They come off the federal lands onto our property (Interview 14).”

Another conservation-oriented landowner on the Middle Fork explained, "Weeds are something that we need to really really work with and get cooperation.... I can't over emphasize how big of an issue weeds are. It's something that is difficult to get everybody on board with because its hard too put your money into fighting weeds when really it doesn't help you out for years to come (Interview 1).” 


\section{Influences on Decision Making}

Five main drivers were identified as influencing land use and land management decisions. These drivers are identified in Table 6 and then explained in further detail.

\begin{tabular}{|l|l|}
\hline $\begin{array}{c}\text { Conservation-Oriented } \\
\text { Landowners }\end{array}$ & \multicolumn{2}{c|}{$\begin{array}{c}\text { Production-Agriculture-Oriented } \\
\text { Landowners }\end{array}$} \\
\hline • Fish habitat & • Finances \\
- Management plans & • Health of the land \\
& - Public pressure and personal relationships \\
\hline
\end{tabular}

\section{Table 6: Main Influences on Decision Making Described in the Interviews}

$\underline{\text { Fish Habitat and Management Plans }}$

Each of the public or conservation-focused landowners along the Middle Fork identified salmon habitat as a major driver of their land management decisions. The same landowners also cited guidance documents, plans, and agency/organizational policy that guide their decisions of what to do on their property. The Warm Springs employee interviewed identified the Oxbow and Forrest Conservation Area Management Plans, the Forest Service employee identified the Forest Plan, and The Nature Conservancy employee referred to both Nature Conservancy policy and Environmentally Based Interactive Pest Management. This group of conservation-oriented landowners along the Middle Fork included two private landowners who both explained that they had purchased their properties at least in part for conservation purposes and also managed primarily for salmon with the assistance of agency guidance.

The Forest Service is unique as a federal agency and is required to comply with the National Environmental Policy Act (NEPA) which includes a public comment phase 
on most project types. On certain types of projects public opinion also influences the decisions made on Forest Service lands.

\section{$\underline{\text { Finances }}$}

The rest of the private landowners on the Middle Fork and throughout Grant County identified three commons drivers in their decision making: finances, what's good for the land, and public pressure. All but one of the private landowners who manage for production agriculture identified finances as a major driver in their decision making. One individual from a longtime ranching family put it quite succinctly, "What influences me? Number 1 is the economics of it. You can experiment with a lot of different things, but you can only make about 1 mistake in ranching and then you're done (Interview 9).”

One of the natural resource managers interviewed explained, "People don't do things because they want to impact the environment. A landowner doesn't go out there and put a big pushup dam in because he wants to go out there and kill fish. He's worried about feeding his family...(Interview 4).” This comment relates back to the misperceptions of ranchers as anti-environment or "bad guys" in the environmental community, as discussed earlier in the section on changing perceptions of the western rancher.

\section{Health of the Land}

Despite their perceived reputation as anti-environment, almost every one of these same landowners also mentioned the health of the land as a major driver in their decision making. One private landowner offered this insight into the interaction of finances and stewardship, “It has to be mutual....if it benefits you as much as it benefits the resource, 
then you're going to do it (Interview 15)." Another private landowner from Grant County expounded on this concept of stewardship, "I have a deep sense that we should leave this land in better shape than we got it. I've convinced myself that that's very possible and really should be expected (Interview 13)."

\section{$\underline{\text { Public Pressure }}$}

One of the same landowners quoted above who cited leaving the land in better shape as a key part of his decision making also acknowledged the role of public pressure on his management techniques, "Public pressure probably influenced me the most on the public lands with grazing. It was obvious to me that I wasn't going to continue doing it the way that it had been done generation before me if I wanted to stay there. So that influenced probably a lot of what I did there. To be honest with you I was pretty nervous about it to start with, but it didn't take long to see the benefits not only to me but to the resource also. I know what I probably started learning out on some of my Forest Service allotments, I can apply the same experience and knowledge that I've gained to the private lands that I've managed now (Interview 13).”

One individual from a long time ranching family on the Middle Fork described another form of public pressure. In describing his decision to lease some of his water rights for in-stream purposes he divulged, "I thought it was something that I needed to do, not just financially at the time. Because I'll pay for it in the long run in loss of production. But I needed some cash at the time and I thought that was something we could do that would not just raise the cash but it would show that we do care about the fish and maybe stave off some litigation (Interview 9)" 


\section{Barriers and Constraints}

The land managers interviewed described regulation and financial challenges as the most common barriers to implementing the practices and seeing the results they would like to on their land. As a logger and rancher from a family with deep roots in Grant County explained, "Probably the worst is federal regulations and the second is dollars (Interview 14).” Additional constraints described included resistance to change among others in the community, upstream land management's effects on downstream landowners, litigation, taxation, and trespass grazing.

\section{Regulation and Permitting}

Regulation and permitting were the most commonly described barriers to land management. Both conservation-oriented and production agriculture-oriented landowners described this challenge. Frustration was expressed with both the multitude of agencies one must consult with and the general attitude of the regulators. As one Grant County rancher described the situation, "Well now in the state of Oregon we have like 9 different agencies that we have to deal with to go down in our river and do something to help the fish. Division of State Lands, ODF\&W, Oregon Department of Ag, oh my gosh! DEQ- it just never ends (Interview 15).”

A conservation-oriented private landowner on the Middle Fork reflected on his experience with implementing a restoration project on his private land. According to him, the regulatory agencies “don't come to the table saying 'We're here to help make this good project go.' It's 'Well, prove to us that you're not going to screw it up.' (Interview 5).” Another conservation-oriented land manager from the Middle Fork 
lamented, “I'm trying to take on a project that is supposed to help you de-list these species and you're making me go through the same thing that you would make me do if I were putting in a Walmart parking lot (Interview 16).” Across the board, frustration with the permitting and consultation process for instream work was expressed. It should be noted, however, that a general understanding and acceptance for the purpose and need for regulation was also expressed by many of these same individuals. 


\section{$\underline{\text { Financial Constraints }}$}

Interestingly, the second most commonly described constraint- finances- was brought up by 4 of the private landowners. None of the public or conservation-oriented land managers described economic issues as limiting or constraining what they do. Private landowners, however, identified economic considerations as limiting what they are able to do and constraining how they manage their land.

\section{Barriers on the Middle Fork}

Among landowners on the Middle Fork, the next most frequently described barriers were upstream land management practices and resistance to change. Two conservation oriented land managers mentioned upstream land management practices of the Forest Service impacting what downstream landowners could do. These comments were made in reference specifically to restoration and weed management actions that conservation-oriented land managers want to implement but that cannot be successful unless they are being addressed on a watershed scale.

Skepitcism, resistance to change, and being coined "environmentalists” for engaging in certain activities were described as constraints by at least three Middle Fork landowners or managers. Given that the prioritization of conservation-oriented activities is relatively new to this community, this form of social criticism is not a surprising result. Other Barriers and Constraints

Litigation was described by both public and private landowners as a major barrier to doing the work they otherwise felt they should be doing. Multiple interviewees lamented the time spent in meetings and away from their jobs, whether they be 
conservation-or agriculture -oriented. Multiple private landowners described taxation, particularly inheritance taxes, as major barriers to maintaining the rural lifestyle their predecessors meant to hand down to them. One conservation oriented landowner who allows limited grazing on his land also described trespass grazing as an issue on his property. 


\section{Part III: Significant Findings}

Several themes emerged from the interviews. The significant findings highlighted here provide insight into the values of the community as a whole and point towards solutions, common ground, and ways that the community might adapt to be more resilient. Many of these findings have implications for management and communication across land ownerships throughout the county and beyond. The emergent themes include topics like balance, sustainability, and stewardship, as summarized in Table 7. These topics were not brought up in the interviews by the researcher; instead they arose independently in the conversations and were identified during data analysis.

\begin{tabular}{|c|c|}
\hline Opportunities for Common Ground & Issues of Contention \\
\hline $\begin{array}{l}\text { - A common desire for balance } \\
\text { - The concept of sustainability } \\
\text { - Seeing ranchers as stewards } \\
\text { - Keeping ranches whole }\end{array}$ & 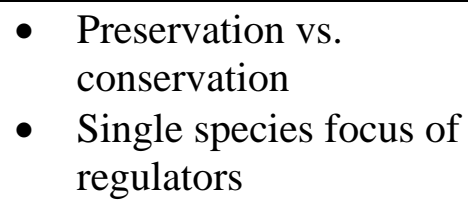 \\
\hline
\end{tabular}

Table 7: Summary of Significant Findings

\section{A Common Desire for Balance- "There's no middle ground.”}

The most common and overarching theme that emerged from the interviews was a desire for balance. The individuals interviewed used words like “pendulum,” "sine wave,” and “meander” to describe the ways they’ve seen land management practices, policies, and attitudes change from one extreme to another over time. As one natural resource manager who works throughout the county put it, “There’s no middle ground. Like I said, it's a pendulum. We're over here to the extreme now and we need to kind of come back to the center (Interview 4).” This sentiment was echoed time and time again. 
The topic of balance provided a venue for talking about related frustrations and hopes, such as polarization, politics, sustainability, and opportunities for reaching common ground.

All of the interviewees pointed towards ongoing litigation as a driver of continued imbalance and polarization in their community. Specifically they expressed frustration with the ongoing litigation between the federal government and the Oregon Natural Desert Alliance about ranchers’ use of federal grazing allotments on US Forest Service and Bureau of Land Management public lands. Multiple individuals described it as a waste of money, a waste of time, and a distraction from the real work of resource management they are all involved in, from either the conservation- or production agriculture-perspective. As a public land manager voiced, "We know what the issues are. We're just choosing not to deal with them.... The community is choosing not to deal with those. they're letting litigation drive the issues (Interview 11).”

Many of the individuals interviewed expressed frustration with how a few individuals with extreme views on either side of an issue could so heavily dominate the dialogue around natural resource issues in Grant County and elsewhere in Oregon. When asked what concerned him most about land and water management in the County, one private landowner from the Middle Fork responded, “The inability to meld the twin objectives of keeping this an economical, socially viable community and protecting and restoring the ecosystem out here. There are more and more collaborative efforts to try and meld those together, but ... the ability to move the needle very significantly is really impaired by the very loud voices on the fringes, like a lot of politics today (Interview 5).” 
This addresses another theme that emerged from the interviews- the concept of a need for balance between the economic, social, and ecological resources in the community.

\section{Sustainability- "Sustainability is not even a topic that's brought up today."}

Time and again the need for sustainable solutions was discussed. As a longtime rancher from the Middle Fork put it, "We've lost the balance and that. Sustainability is not even a subject that's brought up today (Interview 10).” Most of the ranchers voiced concerns that current natural resource management is so focused on fish that policies which destroy economic and social capitol are being adopted without question. A long time natural resource manager in the county described one of his fears for the future this way, "I just hope that we don't lose this concept that we can have jobs and income for our people and still have a great watershed...(Interview 12)”

Given Grant County’s long and intimate history with natural resource management, individuals have a deep seeded belief that a balance between social, economic and environmental needs can be found. As a long time rancher and logger from the county professed, "We have to take care of our ecological production unitthat's our forests and our land and our water. We take care of those and they'll pay for us (Interview 14).”

In the minds of many of the ranchers interviewed, the current flood of funding into conservation-oriented activities is neither a sustainable nor holistic approach to natural resource management. Reflecting on the shifts in land ownership towards conservation-oriented owners along the Middle Fork and elsewhere, the natural resource manager quoted above considered, “It doesn't matter if the government can buy 1100 
acres here and there. If they do it right they can set up good models so that those can be followed but the total health of the watershed will never be determined by a postage stamp piece of ground (Interview 12)." Another rancher offered, “There's no difference between private lands and public lands as far as the conservation of the whole watershed (Interview 8),” suggesting the need for working across land ownerships..

The need for integrated solutions that are economically and socially viable and can operate across private and public ownerships was pointed out numerous times. As a conservation-oriented private landowner from the Middle Fork acknowledged, "It's a hard thing when you go to a public meeting and you're talking about spending money and people are saying 'Well, we can barely afford to keep our schools open. We want to put this money to do this restoration? Where's the trade-off here?' (Interview 17)." Again, the need for balance comes to light.

\section{Preservation versus Conservation- “Anything that has life, you can't preserve it.”}

Based on the responses of the ranchers interviewed, a key component of the polarization and imbalance currently at play appears to be lodged in the framework from which ecological goals are defined. The difference between preservation and conservation is another topic that was brought up repeatedly by the ranchers interviewed. At least 3 individuals brought up this distinction and described how it affects natural resource management. As a Middle Fork resident and long time rancher explained it, "The biggest thing is- it may be an honest attempt, or a sincere attempt- but I think they're misguided in that resources cannot be preserved. Anything that has life, you can't preserve it. It's going to change. And I think some of the ideas that are the norm 
today are going to prove to be detrimental. To the land and definitely to communities (Interview 10).”

Another rancher from an old time Grant County family echoed this sentiment and pointed towards an alternative objective that might unite the ranchers and conservationists more successfully. "The simple fact is the world we live in today has been altered by man. You can't go back to the way it used to be. So the objective at this point should be to manage it to the best of your abilities. And I can assure you that the preservationist attitude won't work. Conservation is a great thing. But so many people think conservation means preservation. And I see that battle getting bigger all the time (Interview 13).” The paradigm shift proposed here may provide a strong foundation for working towards the common goals of managing the land to the best of one's abilities.

\section{Single Species Focus- “You've got to keep the whole picture in front of you."}

Another important component of the perceived imbalance is the current single species focus that dominates natural resource management. As one Grant County rancher put it very well, "Right now the fish thing is just totally out of balance. And the wildlife are just as important. The range is just as important as the wildlife. The hydrology is just as important as the range. But it all has to work together for a healthy ecosystem. But right now our focus is just strictly fish. There's other things that are suffering because of it (Interview 8).” This frustration with a constant focus on fish above not only economic and social aspects of the community, but also other ecological aspects, was brought up multiple times. 
Another rancher reflected on how this single species focus relates to the preservation paradigm described above. "What I am concerned about is the preservationist attitude that keeps pushing. Because I know that just fencing something off and thinking that the problem is solved will not work. And it will have effects that are negative on resources. You can't be so narrow minded that you think cows are all that you need to be concerned with, or timber is all that you need to be concerned with, or fish is all you need to be concerned with. You've got to keep the whole picture in front of you (Interview 13).”

As another described it, "I think that we are compartmentalizing resource management in to riparian streams, riparian zones, uplands, rather than managing from the top of the ridge to the top of the ridge and the whole thing as one (Interview 14).” In their own terms those interviewed repeatedly described the need for management that accounts for environmental, social, and economic needs throughout the watershed and throughout the community. As they describe it, this perspective is inherent to cattle ranching.

\section{Ranchers as Stewards- "We're the ones that are managing for a hundred years."}

The ranchers interviewed often described being perplexed by how natural resource issues have become as polarized as they are given how much they too care for the land and water on which their lives depend. As one Grant County rancher put it, “People that make a living off the land do not intentionally abuse it. They just don't (Interview 13).” He went on to attest that while previous practices may have proved to be 
detrimental to the land, he doesn't believe his predecessors or others in the industry knew better at the time.

A relatively new conservation-oriented private landowner on the Middle Fork extended this sentiment to loggers as well. As he explained, “Knowledge is power. If people understood what you were trying to accomplish... I mean these old loggers they've been in the woods, they know how the forest works, they've got some interesting knowledge they could share. But nobody asks them. They just think "You guys are not scientists, you're just loggers, you just cut the hell out of the forests." Well that's ignorant too (Interview 5).”

Many of the ranchers interviewed described their desire to leave the land they manage in better condition than they got it. As a younger rancher from a long time ranching family explained, "We're as big of conservationists, ranchers in general are, as anyone else (Interview 8).” He later went on to draw a distinction between ranchers and some of the natural resource managers who may not be long time members of the community, “The ranchers are the ones. We're not going to retire at age 50 and take our pension and forget about the bull trout and go off in a motor home somewhere. We're going to be here, our kids are going to be here. We're the ones that are managing for a hundred years and the agencies aren't.” High turnover rates, career-span timelines, and inconsistency among agency personnel were described as related frustrations.

The false distinction between ranchers and natural resource agency folks as “against the land” versus “for the land” was brought up by another Grant County rancher who described the valuable wildlife habitat on his land. "I winter thousands of head of 
wildlife, thousands. And so if I'm put out of business by all this regulation and all these environmental lawsuits and stuff, does anybody know what's going to happen to all my habitat? You know, I'm the fish guy. I mean, I've got miles of habitat- miles! (Interview 15).” The ecological importance of the large tracts of land owned by ranchers is a tremendous opportunity for collaboration between the agriculture and natural resource interests in Grant County.

\section{Common Ground- “That's what Grant County has, the beautiful open space.”}

One of the most significant themes to emerge from the interview data here is the desire to maintain a lifestyle and a landscape that are unique to Grant County. One of the newer landowners on the Middle Fork put it best when he explained his hopes for the future, that the community "focus the energy and the political, economic, and social resources on accomplishing visions for Grant County and this region that sustain the lifestyle that we all love out here (Interview 5)."

This acknowledgment that there are common goals and values shared by the ranchers and conservationists alike provides an opportunity for collaboration. "That's what Grant County has, the beautiful open space. But I can tell you right now, I can look at every piece and tell you who owns it. It's in 4 or 5 hands. It's these big ranches that are still holding it together. And that's what provides that open space that everybody thinks is so gorgeous about the John Day country. But, boy, I'll tell you what. It's not in good shape. It's pretty fragile (Interview 15)."

Keeping ranches whole could enhance the resilience of both the ecosystem and the social fabric of the community. As one long time rancher who's debated selling parts 
of his land explained, "what happens is a ranch gets in trouble financially and they say ok we'll sell that 160 out back, we could get by without that and that'll bail us out. Well yeah. But now out back instead of sitting in the middle of 50,000 acres of winter habitat for deer and elk, now you've got a house, kids, and dogs and horse stables and you've disrupted 50,000 acres of winter range. So every time that happens we're taking away a little bit of what we all love about this. It's the open space. It's the big blocks of open space that we all love and would like to see (Interview 9)." Breaking up the land also results in different management strategies being employed on adjacent properties, some of which may or may not meet the goals and desires of the natural resource management agencies.

A conservation-oriented private landowner on the Middle Fork remarked on this same issue, "That's another thing you see is a real resistance to breaking up properties. They do not want to see properties broken up into little ranchettes and those types of things, they want to try and reserve the bigger pieces. And from a conservation standpoint that's great! (Interview 17)" Acknowledgments such as these may pave the way towards a less polarized discussion around natural resource issues in Grant County. It may also inspire ideas for sustainable land management practices that can benefit the ecologic, economic, and social resources of the community. 


\section{Chapter 5: Discussion}

\section{Summary}

Numerous changes are afoot in Grant County. It is evident that restoration in the Intensively Monitored Watershed is having impacts on land use and land management but it is not the only driver of the changes described by the residents interviewed. The decline of the timber industry, shifting economics of cattle production, and larger trends of population reorganization in urban and rural areas all appear to play a role in the changes in land use and landownership occurring along the Middle Fork and elsewhere in Grant County. Parsing out the role of restoration and other conservation-oriented activities alone is challenging, as they are intricately linked to these other issues.

A concept map of these intricate linkages was presented in Figure 6. This map depicts the social, economic, and ecological changes described by the research participants and attempts to show how they relate to one another. Though many, many more changes were described than appear in this figure, the map is meant to show the most frequently described or most significant changes. In most cases the relationships between the various changes described are not one-directional. In the summary and discussion that follow, a more detailed description of the most significant changes and their implications for land managers, regulatory agencies, and the IMW are described. Ecological Change

The main changes described by those interviewed include improved ecological conditions and degraded economic and social conditions. Those interviewed describe rivers and rangelands as being in better condition now than they have been for a long 
time. They ascribe the improved conditions to fewer cattle, rotational and seasonal grazing patterns, intensified regulation of water use, and restoration activities. The individuals interviewed do not feel the same way about forest conditions. Generally forest conditions are viewed as having worsened in the recent past, though previous eras of overharvest and extreme fire suppression are also looked back upon critically. These opinions were generally shared among production agriculture- and conservation-oriented individuals on the Middle Fork and elsewhere in the county.

There are a variety of land management practices that appear to be improving the health of the land. Many of these practices are associated with grazing since that is the most common land use described by both public and private land managers interviewed here. These practices include riparian fencing, rotational grazing schedules, irrigation efficiency projects to improve water quality as well as quantity, and weed management. No single practice has been adopted by all of the landowners and interestingly, different landowners have different reasons for using the same practices. This point speaks enormously to the unique qualities of ranchers and ranchlands in the John Day Basin. As several interviewees confirmed, the values of independence, common sense, and personal freedom are intrinsic to the ranching lifestyle. There is no one size fits all solution to natural resource issues in this social-ecological landscape. As will be discussed further in the recommendations section of this discussion, embracing this fact and looking for ways to incorporate common values and sense of place into management will be useful to restoration practitioners and regulators who are striving for further ecological improvement on the land. 


\section{Social, Cultural, and Economic Change}

As is expected when one studies social-ecological systems, the ecological changes in the community could not be discussed without also acknowledging the social, cultural and economic changes also taking place. According to lifetime residents of Grant County, social and economic conditions are getting worse. Class sizes in the local schools are getting smaller, young people have to leave the county to find work, and Grant County's population is decreasing (See Table 2). All of the lifetime residents interviewed were engaged in cattle ranching and/or timber harvest for employment. Newer residents of Grant County generally described a more vibrant, or at least more hopeful, picture of social and economic conditions. The vast majority of the "newer" residents, some of whom had been living in Grant County as long as 33 years, live along the Middle Fork and do not depend on ranching or timber harvest for income. These individuals, whether public or private, manage for fish habitat and are engaged in large scale restoration efforts funded primarily by the federal government and Bonneville Power Administration. While these conservation-oriented individuals pointed out opportunities like job creation in the restoration economy, they were in general agreement about the depressed economy and limited social resources elsewhere in the county.

The opposite trajectories of the environmental and socio-economic conditions in the community are directly and indirectly related. On the Middle Fork, increased conservation-oriented land ownership is reducing the opportunities for cattle grazing on parts of those properties. In some cases it is also reducing tax revenues. The Forest 
Service's reduced timber harvest, increased scrutiny over federal grazing allotments, and increased focus on fish habitat enhancement are also reducing the income they bring into the community. Throughout the county, increased regulation of water and land use are driving down profit margins by limiting the amount of land that can be used for grazing or the amount of water that can be used to irrigate hay fields.

The fact that opportunities for making a living off the land are becoming more challenging because of these environmental pressures as well as other economic drivers means that an increasing number of ranch families are going out of business and selling their land to the highest possible bidder. Along the Middle Fork the highest bidder is usually a conservation-oriented landowner like The Nature Conservancy or Warm Springs Tribe, but elsewhere in the county the highest bidder may be a developer or sometimes a fellow rancher. Understanding that these trends are in place at the same time may help land users and managers in understanding and better navigating the “environment versus jobs” dichotomy that currently dominates natural resource issues in the county. Understanding the influences in land managers’ decision making may provide similarly useful insights.

Influences on Land Use and Land Management

When it comes to decision making- finances, the health of the land, and public pressure were the top three influences describe by private landowners. Interestingly, these influences mirror the three pillars of sustainability: economics, environment, and society. As was discussed in the Significant Findings earlier, multiple ranchers interviewed brought up the concept of sustainability and encouraged its widespread 
adoption. They critiqued the conservation-oriented landowners and managers as being too fish-focused and not addressing the social-ecological system holistically. In line with this observation, the conservation-oriented landowners identified their management plans and fish habitat as the main drivers of their decisions. Finances and social considerations were not mentioned by any of the conservation-oriented landowners.

Restoration in the John Day Basin is a high priority and as such it is well funded. The fact that conservation-oriented landowners failed to mention finances as a component of their decision making is testament to the funding environment they operate within. Given the economic fragility of other industries in the county, it is worth looking for mutually advantageous projects, markets, and business models that can meet conservation-goals while contributing to socio-economic resilience in the county. It is also likely that this funding rich environment will lessen in the coming years, so maximizing the current funding sources to invest in social and ecological resilience will pay dividends in the future.

\section{Opportunities for Adaptation}

The information gathered through these in-depth interviews can be used to inform community-based natural resource management on the Middle Fork and elsewhere in Grant County. The private landowners interviewed were chosen for this research because they either own land amidst the rash of restoration taking place on the Middle Fork, or they are seen within their community as successful individuals who have been able to ride the waves of change. There is much to be gained by looking for ways that restoration and conservation activities could better address the social and economic needs 
of the community and be embraced by local residents as an opportunity rather than a threat.

Diversification of one's economic base allows for a level of resilience during periods of significant change. The landowners interviewed rarely referred to their land management or their economic base as solely dependent on one activity or one strategy. While they may have identified as a rancher or a logger, they described a variety of activities taking place on their land. Whether that be diversifying the lands used for grazing so as not to depend too heavily upon self-owned property or federal grazing allotments, or supplementing grazing income with timber harvest, gravel mining, leasing a water right, or managing a bed and breakfast, the private landowners interviewed rarely depended upon a single market or single trade for their income. Below, several opportunities for diversification are described.

\section{The Restoration Economy}

As all of the conservation-oriented landowners on the Middle Fork pointed out, restoration creates jobs and there is money to be made in this field right now.

Throughout Oregon the job creation impacts of restoration have been tracked and studied in depth by the Ecosystem Workforce Program at University of Oregon (Nielson-Pincus and Moseley 2010; Hibbard and Karle 2001). It is estimated that forest and watershed restoration creates between 15.7 and 23.8 jobs per $\$ 1$ million dollars of public investment, depending on the type of work being done. Restoration work also results in an additional 1.4 to 2.4 times the amount of economic activity as that money cycles through the economy (Nielson-Pincus and Moseley 2010). 
On the Middle Fork alone, nearly \$3 million has been spent on 33 restoration projects since 1995 (Oregon Explorer 2011, data illustrated in Figures 3 and 4). Over \$8 million has been spent on 232 restoration projects in all of Grant County (OWRI 2011). In many cases these projects are providing employment to out of work loggers, underemployed construction workers, and other who can apply their heavy equipment operation skills and knowledge of the area to fish focused projects. The ripple effects create additional employment in nurseries that source plants for revegetation projects or metal fabrication shops that build fish screens for diversion ditches. Direct employment is also provided by the agencies, tribes, watershed councils, Soil and Water Conservation Districts and other organizations that manage or provide technical assistance to these projects. This economic stimulus was suggested to be a significant reason for why restoration has been at least partially embraced as an adaptation to the changing social and economic conditions in Grant County, particularly on the Middle Fork.

Concerns have been raised about whether the restoration economy can help Grant County become more resilient or if instead it may be just another fad industry that will boom and bust. As a production agriculture-oriented landowner who leases land on the Middle Fork expressed, "One of the things that I see as kind of a problem with where we are at right now in what people like to call this "restoration economy"- it's pretty shortlived. And it's not very stable. (Interview 14).” Before blindly embracing the restoration economy as a fool-proof solution for the environmental, economic, and social ills of Grant County, further analysis is required. Dependence on federal funding, a single species rather than ecosystem focus, and tendency to boost the regional rather than local 
economy were brought up by interviewees as significant faults of the emerging restoration economy in Grant County. Each of these critiques relates back to the issue of sustainability. Instead of seeing it as the one and only solution to economic fragility, one might instead look at the restoration economy as playing a role in the diversification of an individual's bottom line in Grant County.

\section{$\underline{\text { New Markets }}$}

Some of the other ways ranchers are diversifying appear to provide real income generation that could be helpful for others in the county. The new markets being used to diversify were described in Part II of the Results chapter earlier. Three of the six respondents who talked about these new markets ended up serving as key interviews in this study largely because they were viewed by their community members as successful and forward-thinking; some of the best examples of individuals who have so far been able to ride the tide of change and still come out on top.

Fee hunting surfaced as a promising potential market. Two of the landowners interviewed described increasing demand, surprising profits, and minimal costs to those who maintain hunting rights on their land. One of the landowners actually described such a demand that he can no longer afford the time to guide hunting trips and now contracts with a private third party company to do so. A recent study conducted by Dean Runyan Associates found hunting associated travel expenses generated a total of \$5,137,662 in Grant County in 2008 (2009). As Figure 7 depicts, fishing and wildlife viewing also contribute substantial amounts of spending for a total of $\$ 11,563,891$ in recreation- related travel expenditures in Grant County in 2008. This same study found 
that the vast majority of these trips are overnight travel, which magnified their costs beyond just equipment and guide costs to also include lodging, local amenities, and other travel-associated spending (2009).

\section{Grant County}

Travel-Generated Expenditures, 2008

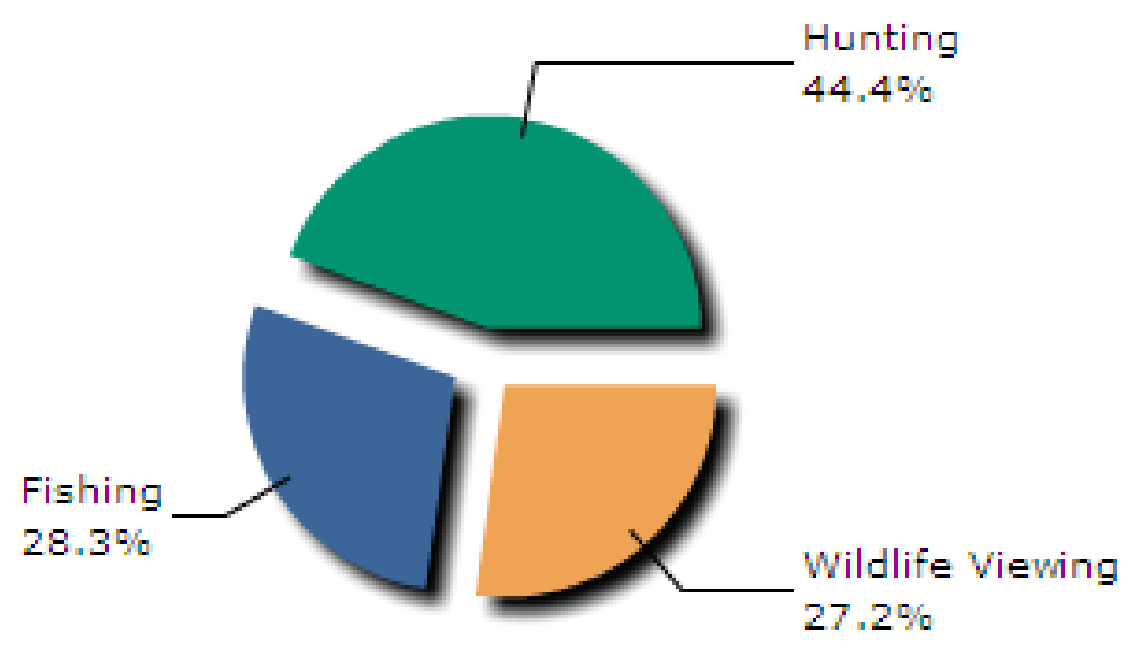

Figure 7: Grant County Travel-Generated Expenditures from Hunting, Fishing, and Wildlife Viewing in 2008. Source: Dean Runyan Associates (2009).

Another activity that is being used to diversify a household's economy is the hospitality industry. Multiple individuals interviewed described tourism as an underappreciated opportunity in Grant County. One Middle Fork landowner offers ranch stays at a cabin on his property, providing farm fresh eggs, horseback riding, and snowshoeing trips. Another family with land on the mainstem John Day River runs a bed and breakfast in an old school house on their property. By themselves it is unlikely that any of the activities described here could support a family, but they may contribute to a more resilient household and local economy. 
Two other niche markets came up in the interviews. The first, professional ranch consulting services, was described by just one Grant County rancher, but the need for this service has been predicted in other areas where similar population and demographic changes are resulting in new ranch owner with little ranching experience (Brunson and Huntsinger 2008). The second niche market described was raising cattle for the sustainable, grass-fed beef markets in Portland, Salem, and other affluent communities west of the cascades. Though Country Natural Beef, formerly Oregon Country Beef, originated in Eastern Oregon and has proven to be a successful business model, only one interviewee described participating in this market.

\section{Conservation Easements}

Conservation easements are another tool that private landowners are using to diversify their personal incomes and business practices while contributing to conservation goals. Existing programs such as the Conservation Reserve Enhancement Program (CREP), Columbia Basin Water Transaction Program, and Oregon Department of Fish and Wildlife’s Bonneville Power Administration-funded John Day Habitat Enhancement Program are being used by private landowners on the Middle Fork and elsewhere in Grant County. Conservation easements have been proposed in other communities as a solution for more resilient social-ecological system, though as is noted here, there are pros and cons to the various government-run programs currently offered and conservation easement programs are generally more successful when run by local or ranchers’ organizations (Brunson and Huntsinger 2008). 
CREP is a longstanding program managed by the Natural Resources Conservation Service which pays landowners to plant, fence, and protect their riparian areas. The landowners receive an annual payment per acre enrolled in the program. Through this program the government is in effect renting the landowners land for conservation purposes during the time of the agreement. The program also offers cost-share opportunities for improvement projects like fencing and revegetation. As one of the ranchers interviewed who just recently enrolled his land in CREP explained, "In order to get the interior fences to manage the cattle properly we needed help to do it. And so if we're going to get paid to build the fences and get a rental payment, it more than offsets the sacrifice (Interview 10).” In this landowner's case, the benefits of the fence and payments for the esaement outweigh the costs of taking the fenced land out of production. Throughout the United States, CREP has not been embraced as fully as natural resource managers hoped because the benefits do not always outweigh the costs (Lovell and Sullivan 2006). Assistance with fencing to manage cattle is also provided by the ODFW program.

The ODFW program provides riparian fencing and maintenance of that fencing for 10-15 years. This program was identified by multiple landowners as particularly effective because the assistance with maintenance is crucial. As was heard in the interviews, conservation-oriented practices must be mutually beneficial- to the land and to the landowner- for ranchers to adopt them. Fencing alone, or fencing along with payments for the excluded land taken out of production, may sometimes not be enough to convince a landowner to take that land out of production. Wildlife like deer and elk are 
known for tearing down fences and when that happens the landowner is left to repair them or have cows in the wrong pastures or in the stream. Assistance with maintenance through ODFW's program makes this a particularly popular program.

At least four of the landowners interviewed have participated in the Columbia Basin Water Transaction Program. Most of them have participated in multiple deals through the Freshwater Trust. It is possible that more individuals have participated in this program but did not refer to it by name during the interviews. Table 8 shows a summary of water rights transfer agreements in the Middle Fork subbasin made through this program over the past 8 years. As the table shows, over $\$ 2$ million dollars in direct payments have been made to Grant County landowners for returning some or all of their water rights to the river for a month, a year, or forever. These agreements are tailored to the needs of the landowners and the streams. Some are season long, some are only for 12 months of the season, and the length of time the commitment is made for varies as well. A landowner can see how the leasing program works in one year and decide the next year whether or not they want to participate in it again. Some choose to sell their water rights in perpetuity all at once. Again, this site specific flexibility and adaptability is probably a major reason for why the program has been rather successful. It is being adopted in other parts of Grant County as well, particularly on the mainstem John Day River where water shortages are a major ecological concern. 


\begin{tabular}{|l|r|r|r|}
\hline \multicolumn{1}{|c|}{ Transaction Name } & \multicolumn{1}{c|}{ Year } & \multicolumn{1}{c|}{$\begin{array}{c}\text { CFS } \\
\text { Restored }\end{array}$} & \multicolumn{1}{c|}{ Water Cost } \\
\hline $\begin{array}{l}\text { Middle Fork Ranch Partial Season } \\
\text { Forbearance Agreement }\end{array}$ & 2004 & 5.71 & $\$ 19,000$ \\
\hline RPB & 2005 & .9 & $\$ 18,900$ \\
\hline Middle Fork Ranch & 2005 & 5.04 & $\$ 19,000$ \\
\hline Standard Creek Forbearance Agreement & 2006 & 4.93 & $\$ 55,000$ \\
\hline Austin Ranch Diminishment & 2006 & 10.2 & $\$ 700,000$ \\
\hline Dunston Ranch Transfer & 2007 & 3.77 & $\$ 110,000$ \\
\hline Roberts Creek Wilderness Water & 2009 & 7.14 & $\$ 34,986$ \\
\hline $\begin{array}{l}\text { Standard Creek Flow Based Forbearance } \\
\text { Agreement }\end{array}$ & 2010 & 4.93 & $\$ 11,750$ \\
\hline Pine Creek Permanent Donation & 2010 & 1.92 & $\$ 101,760$ \\
\hline $\begin{array}{l}\text { Lower Rudio Creek Late Season POD } \\
\text { Change }\end{array}$ & 2010 & 2.00 & $\$ 140,000$ \\
\hline Lower Island POD Mid Season Shutoff & 2010 & .72 & $\$ 3,843$ \\
\hline Hawkins Creek Donated Lease & 2010 & .43 & $\$ 8,170$ \\
\hline $\begin{array}{l}\text { Roberts Creek Wilderness Water Permanent } \\
\text { Protection }\end{array}$ & 2011 & 5.59 & $\$ 890,000$ \\
\hline Berry Creek & 2011 & .74 & $\$ 4,776$ \\
\hline Total of 14 transactions in John Day Basin & & $\mathbf{5 4}$ cfs & $\$ 2, \mathbf{1 1 7 , 1 8 5}$ \\
\hline
\end{tabular}

Table 8: Columbia Basin Water Transactions Program Agreements in the John Day

Subbasin. Source: Columbia Basin Water Transactions Program 2011. 


\section{Valuing Other Ecosystem Services Provided by Rangelands}

Ranchers have found several ways to make supplemental income off ofservices that their lands provide to the general public or the conservation community. These include the recreational tourism, conservation easement, and water rights markets. Another opportunity for collaboration between production agriculture- and conservationoriented land managers which is not yet embraced in this community is reimbursing ranchers for the open space and pastoral landscapes that are provided by rangelands actively used for agriculture. Again and again the conservation- and production agriculture-oriented landowners interviewed reflected on the open space, independence, and beautiful landscapes of Grant County as key attributes that keeps them living there and working so passionately. Yet the difficult economic reality of cattle ranching coupled with intensified regulation, inheritance tax burdens, and development pressure all threaten this unifying sense of place shared by nearly all of the interviewees. As was discussed in the final section of the results, keeping ranches whole is a common goal of conservationists and ranchers in Grant County.

When ranches are broken up so are the open landscapes that make Gant County unique and that provide contiguous habitat and consistent management for aquatic and terrestrial species. While conservation easements are currently being used in an attempt to help landowners get reimbursed for the conservation value of their properties, these easements are generally limited to riparian areas and require the exclusion of cattle. They do not value the other ecosystem services provided by working landscapes. An alternative to the classic conservation easement model is being explored by groups such 
as the Sustainable Rangelands Rountable who are working to quantify the many ecosystem goods and services provided by rangelands (Maczko and Hidinger 2008, Maczko et. al. 2011). A pilot project to quantify these goods and services is underway in Central and Eastern Oregon, including Grant County.

Throughout the United States, the concept of multifunctional agriculture is gaining ground. Lands in agricultural production provide more than just foods and fiber, they also contribute towards biodiversity, renewable energy resources, and the socioeconomic wellbeing of rural communities (Romstad et.al.2000, Renting et.al.2009). Ecosystem service markets are emerging as a new mechanism for valuing these goods and services (Costanza 1997). Conservation easements and credit trading are two methods of financial reimbursement that are being used elsewhere as ways to reimburse landowners for the services their lands provide (Maczko and Hidinger 2008). Grant County appears to be a promising area to pilot a market that would reward ranchers for sustainable ranching practices, since the ranchers interviewed repeatedly brought up the need for a more holistic and balanced approach to natural resource management. A market-driven approach might succeed in gathering participation from families resistant to government run programs and handouts. Both the ranching and conservation communities stand to benefit from a collaborative approach to conserving large land ownerships.

\section{Recommendations}

The opportunities for a more resilient social-ecological system discussed above are all concepts that can be collaboratively addressed by various stakeholders- private 
landowners, natural resource managers, local government, and the general public of the Middle Fork and Grant County. The interview data also brought to light numerous opportunities for specific stakeholders including regulatory agencies, the Intensively Monitored Watershed, and restoration practitioners. Common suggestions, issues, and opportunities were brought up by many of the individuals interviewed and it is hoped that sharing this information here will serve to inform decision making among these stakeholders.

\section{$\underline{\text { Recommendations for Natural Resource Management Agencies }}$}

Natural resource management agencies are tasked with balancing competing ecological, social, and economic considerations for the benefit of the general public. In Grant County, federal agencies such as the US Forest Service, National Oceanic and Atmospheric Administration (NOAA), Bureau of Land Management (BLM), and Bureau of Reclamation (BOR) are actively engaged in land and water management on public and private lands. At the state level, Oregon Department of Fish and Wildlife (ODFW), Department of State Lands (DSL), the Department of Environmental Quality (DEQ) provide more localized management. The interviews pointed towards numerous opportunities for improved management and enhanced community relations for these agencies.

As was reported earlier in the results under "Barriers and Constraints," regulation and permitting were described by ranchers and conservationists alike as the most significant barriers to land management in Grant County. Though interviewees generally agreed upon the need for and importance of regulation of water use, in-water 
construction, and habitat alteration, they expressed frustration with the duplicity, tunnel vision, high turnover rates, bureaucracy, and general tone of communications with regulatory agencies. Below are several suggestions for how the agencies might address these concerns and frustrations.

- Consider developing a streamlined permitting team for organizations that work directly with landowners on natural resource issues in Grant County or the John Day Basin. Organizations such as the Grant County Soil and Water Conservation District (SWCD) and North Fork John Day Watershed Council are essential to implementing conservation actions on private property in Grant County. They also work closely with some of the state and federal agencies to contract work out on public lands. Developing a team of local staff from agencies like the Department of State Lands, Army Corps of Engineers, NOAA Fisheries, and US Fish and Wildlife Service to review and comment on a variety of projects (not just restoration actions, which often go through programmatic consultation and permitting anyways) would help to address potential issues early in the process, encourage communication and integration across agencies, and develop relationships between the applicants and regulators.

- Dedicate staff time to outreach and relationship building. Have local representatives participate in SWCD and Watershed Council meetings, attend community forums relevant to natural resource issues or other issues under the agency's jurisdiction, and provide a face for the agency within the community. Some agencies (such as US Fish and Wildlife and Oregon Department of Fish and Wildlife) were regarded 
as already having an on the ground presence, whereas others (such as NOAA Fisheries and Department of State Lands) were called out for being particularly detached and absent from the local scene (note, this recommendation for NOAA is consistent with Coggoila 2010). Interpersonal trust in agency personnel is extremely important in natural resource management (Davenport et. al. 2007). The agency employees tasked with participating in community events and communicating with the public should recognize the value of this work. If they regard it as "fluff" or a task solely for new hires, the benefits that could be gained from their work in the community may be compromised.

- Develop manuals, samples, and other outreach materials focused on target audiences to help clarify and simplify permitting and regulatory processes. Agency websites are notoriously archaic. Regulatory statutes and laws are often written in legal jargon that is nearly incomprehensible to the average citizen. In 2010 President Obama signed the "Plain Writing Act of 2010" for just this reason (PLAIN 2011). Adoption of plain writing techniques will be a slow institutional change but there are many quick and simple things that can be done to improve communications right away. One of those is sharing good examples of permit applications, biological assessments, and other documents so that applicants know what the regulatory agencies are looking for and how they like information to be presented.

- Advertise success. Point out what is working. Several of the ranchers lamented that "It seems when things are bad it gets publicized and when things are good nobody talks about it (Interview 8).” In addition to providing good examples of written 
documents as described above, also consider the value of focusing communications resources towards highlighting success stories. Also consider sharing scientific data on strong fish runs, rebounding wildlife populations, or good water quality in manner that is accessible to the general public, such as website stories or public presentations.

- Take the time to listen and learn from long time residents who have witnessed the ecological and social change described throughout this report. Longtime residents often have first hand experience with the major floods, fires, cold spells, heat waves, and previous land management practices that computer simulated models or textbooks attempt to teach natural resource managers. In a community like Grant County those same individuals have probably spent considerable time on the rivers and in the forests and have developed a stewardship ethic that could be embraced to meet agency management goals.

- Embrace adaptive management as a way to respond to not only the biophysical, but also the socio-cultural, effects of restoration in the Middle Fork. When a restoration technique fails from a biophysical perspective, managers usually won’t apply that same practice elsewhere until they understand why it didn't work and what should be changed. On the other hand, when a communication technique or community engagement strategy doesn't work out, natural resource managers often continue to use the same strategy though they're fully aware of its ineffectiveness. As managers monitor and seek to improve the biophysical effects of restoration on the Middle Fork, they should apply the same diligence and effort to the social, economic, and 
cultural effects. If the John Day Basin really is one of the Columbia Basin's best chances of witnessing salmon recovery and detecting a positive response to management activities, then the very best scientific, social and economic practices available should be used to ensure success.

Implications for the Intensively Monitored Watershed

As a metric proposed as part of the Intensively Monitored Watershed (IMW)'s socio-economic monitoring effort, this research on changes in land use and land management on the Middle Fork and in Grant County was meant to help identify some of the impacts that restoration activities are having in the community. A byproduct of this effort was insight into personal perspectives, experiences, and misconceptions of landowners and managers in the area. These insights reveal numerous opportunities for improved communication, more effective management, and identification of common ground that the IMW and the restoration community can embrace.

The interviews revealed several private landowners within the Middle Fork and elsewhere in Grant County who voiced concern, misunderstanding, or lack of awareness about restoration efforts happening on the Middle Fork. While it appears to be the intent for the Warm Springs and some conservation-oriented private properties to serve as models of agricultural practices that can be implemented with positive environmental effects, those efforts may need to be better communicated. There are also some popular misconceptions (such as the idea that the public is not allowed on the Tribes' land, or that conservation efforts are trying to shut down grazing on the Middle Fork) that could be clarified through targeted communications. The IMW may want to consider providing 
project updates, explanations of the experiments and trends being monitored, or key findings as they emerge through outlets like a newsletter, website, signage, or community meetings. Given the highly scientific nature of the IMW's undertakings, care should be taken to communicate key messages in a format and language that is accessible to the general public.

This research provided an opportunity to explore whether or not there are quantitative metrics that could be used to track changes in land use and land management or other socio-economic impacts of restoration on the Middle Fork and in Grant County. The area of the IMW is small enough that changes in landownership could be tracked directly, if desired. It proved difficult to track the number of cattle or animal unit months (AMUs) on the landscape, though this would perhaps be one of the more interesting metrics to ranchers and other private landowners. Through the interviews several specific land management practices were described that could be tracked individually, these include payments from the Columbia Basin Water Transaction Program, acres of weed treatment, and number of irrigation upgrade project implemented by the Soil and Water Conservation District.

Consistent tracking of the restoration activities being implemented within the IMW and elsewhere in Grant County will ensure that the socio-economic and other cumulative effects of the projects can be tracked and understood. The Oregon Watershed Restoration Inventory (OWRI) is an Oregon-wide project database maintained by the Oregon Watershed Enhancement Board (OWEB). All data in the database is publicly available through OWEB and the Oregon Explorer, so having all of the IMW's basic 
project information within the database will allow for analysis by a wider audience, as well as by the IMW's minimal capacity. The IMW should work with all their project partners to make sure that restoration project information is entered into OWRI.

Particular effort should be made to include projects that do not receive OWEB funding, such as US Forest Service projects, since those are the type of project most commonly missed by OWRI currently. Given the significant amount of Forest Service land in the IMW, and public lands throughout Grant County, increased reporting would help better depict restoration investments and activities.

One of the most significant findings from the research is that there is an as of yet untapped opportunity to mobilize around the concept of keeping ranches whole. Both ranchers and conservationists agree that maintaining large land ownerships is considerably more preferable than seeing the landscape chopped up by subdivisions, ranchettes, and disjointed land management practices. Open landscapes, scenic vistas, and abundant wildlife emerged from the interviews as key components of rancher's and conservationist's “sense of place” in Grant County. As previous research on highly politicized natural resource issues in Oregon has shown, unifying the community around a common sense of place rather than differences shows tremendous promise for deescalating conflict and moving towards community-based solutions (Brown 1995; Yung et. al. 2003). Developing a rangeland ecosystem service market or conservation easement model that could help private landowners maintain their large ownerships would go a long way in encouraging collaboration and moving towards a more resilient future in Grant County. 


\section{Opportunities for Further Research}

Like any field-based research, this study had limitations. This study intentionally focused only on residents of Grant County, with particular focus on the landowners and managers within the IMW and other residents from throughout the county who are involved in practices identified as new, different, or proactive. This study did not seek to explore the understandings of non local stakeholders, those without responsibilities and experience with rural land management, or those staunchly opposed to conservation activities. One interview was conducted with an old time community member who adamantly disagrees with the restoration work going on around her. The interviewer focused primarily on her historical perspective and the change she had witnessed in the area rather than on her personal opinions. To expand the study and include non conservation-oriented landowners and land managers would provide a very useful perspective and be equally important and interesting work. But that was not within the scope or ability of the research conducted here.

This study employed qualitative methodology to explore the lived experiences of local landowners- their values, their perceptions, and their mechanisms for reflection and adaptation. While the quantitative aspects of the associated watershed-scale monitoring effort are documenting some direct and indirect impacts of restoration in the community, a qualitative approach was used in this study to identify values and perceptions that will hopefully give utility and meaning to quantitative measures being collected in this community. Unfortunately, only two years worth of the other socio-economic monitoring parameters have been collected and so limited references to that data were 
included here. As further data is collected a more integrated assessment of the quantitative and qualitative data on the socio-economic effects of restoration in the Middle Fork would be an interesting area of study.

As a contract employee of NOAA Fisheries, this researcher's experiences and perspectives on natural resource management bring a bias to the study and its interpretations. For the individuals interviewed who were aware of the researcher's background, assumptions about that bias or skepticism about the intent of this research may have affected the participant's responses. Though the researcher's experiences were overwhelmingly positive and the interviews felt sincere, open, and frank, it would be interesting for a similar study to be conducted by a researcher with a different background.

\section{Conclusions}

This research used in-depth interviews to document how landowners and natural resource managers from the Middle Fork and Grant County describe changes they’ve witnessed in land use and land management practices. It also explored the issues and values that landowners and natural resource managers identify as influencing their land use and land management practices. Restoration is just one of multiple drivers responsible for changing land use and land management practices in Grant County. It is a stronger driver on the Middle Fork where significant resources are being concentrated than elsewhere in the county. Some of the main changes taking place in Grant County include fewer and larger ranching operations, improved management of natural resources 
through practices like riparian fencing and irrigation efficiency projects, and increased prevalence of landowners who do not manage for production agriculture.

While these changes present many challenges for the ranching community, the interviews identified numerous ways in which private landowners are adapting to changing land use and land management practices in their community. Opportunities exist to diversify by tapping into the restoration economy, conservation easements, and nontraditional ecosystem service markets like fee hunting and ecotourism. These changes may also provide opportunity for more collaborative management between private landowners and the conservation community on issues like maintaining working landscapes for their social, economic, and ecological functions.

The recommendations presented here suggest ways that natural resource management agencies, the Intensively Monitored Watershed, and restoration practitioners can continue implementing high priority restoration actions while also contributing to the social and economic resilience of the community. If John Day is being prioritized for salmon recovery and really is one of the Columbia Basin's greatest chances of delisting a species, innovative approaches to addressing the human and ecological needs of the community must be explored so that sustainable, community-based solutions are found. If this can be achieved in Grant County, Oregon of all places, its stands a chance of setting the stage for successes elsewhere. 


\section{References}

Benson, M. H. and A. S. Garmestani. 2011. "Can We Manage for Resilience? The Integration of Resilience Thinking into Natural Resource Management in the United States." Environmental Management 48(3): 392-399.

Berkes, F. and C. Folke. 1998. Linking Social and Ecological Systems: Management Practices and Social Mechanisms for Building Resilience. New York, NY: Cambridge University Press.

Bewsell, D., R. M. Monaghan, and G. Kaine. 2007. "Adoption of Stream Fencing Among Dairy Farmers in Four New Zealand Catchments.” Environmental Management 40:201-209.

Biggs, R., F. R. Westley, and S. R. Carpenter. 2010. "Navigating the Back Loop: Fostering Social Innovation and Transformation in Ecosystem Management." Ecology and Society 15(2).

Blue Mountain Forest Partners. 2009. "Strategic Plan of the Forest Collaborative of Grant County, Oregon.” Retrieved from: http://sites.google.com/site/bluemountainsforestpartners/

Boody, G., B. Vondracek, D. Andow, J. Zimmerman, M. Krinke, J. Westra, P. Welle. 2005. "Multifunctional Agriculture in the United States." BioScience 55(1): 27-38.

Bowcutt, F. 1999. "Ecological Restoration and Local Communities: A Case Study from Sinkyone Wilderness State Park, Mendocino County, California.” Human Ecology 27(2): 359-368.

Bromley, D. W., G. E. Blanch and H. H. Stoevener. 1968. "Effects of Selected Changes In Federal Land Use On a Rural Economy.” Station Bulletin. 604. Agricultural Experiment Station, Oregon State University. Retrieved from: http://ir.library.oregonstate.edu/xmlui/bitstream/handle/1957/15545/StationBulleti n604.pdf?sequence $=1$

Brosius, J. P., A.L. Tsing, and C. Zerner. 1998. "Representing Communities: Histories and Politics of Community-based Natural Resource Management.” Society and Natural Resources 11(2): 157-168.

Brown, B.A. 1995. In Timber Country: Working People's Stories of Environmental Conflict and Urban Flight. Philadelphia, PA: Temple University Press. 
Brunson, M. W. and L. Huntsinger. 2008. "Ranching as a Conservation Strategy: Can Old Ranchers Save the New West?” Rangeland Ecology \& Management 61(2): 137-147.

Bureau of Reclamation. 2008. "Middle Fork and Upper John Day River Tributary Assessments Grant County, Oregon.” Bureau of Reclamation Technical Service Center, Denver, CO and Pacific Northwest Regional Office, Boise, ID. 113 pages, 8 appendices.

Charmaz, K. 2006. Constructing Grounded Theory: A Practical Guide Through Qualitative Analysis. Los Angeles, CA: Sage Publications.

Cheng, A. S., L. E. Kruger, and S. Daniels. 2003. "'Place' as an Integrating Concept in Natural Resource Politics: Propositions for a Social Science Research Agenda." Society \& Natural Resources 16(2): 87.

Christian-Smith, J. and A. M. Merenlender. 2010. “The Disconnect Between Restoration Goals and Practices: A Case Study of Watershed Restoration in the Russian Basin, California.” Restoration Ecology 18 (1): 95-102.

Coggiola, A. 2009. "NOAA National Marine Fisheries Service Innovative Incentives Project.” Unpublished Report. NOAA, Portland, Oregon. 60 pages.

Columbia Basin Water Transactions Program. 2011. "Transactions Columbia Plateau: John Day.” Retrieved from: http://www.cbwtp.org/jsp/cbwtp/projects/transactions.jsp?sub_basin_id=21

Columbia-Blue Mountain Resource Conservation and Development Area. 2005. "John Day Subbasin Revised Draft Plan.” Columbia River Basin Fish \& Wildlife Program. Northwest Power and Conservation Council. Retrieved from: www.nwcouncil.org/fw/

Costanza, R., R. d'Arge, R. de Groot, S. Farber, M. Grasso, B. Hannon, K. Limburg, S. Naeem, R.V. O'Neill, J. Paruelo, R.G. Raskin, P. Sutton, and M. van den Belt. 1997. "The Value of the World's Ecosystem Services and Natural Capital." Nature 387(6630): 253-260. Retrieved from: http://www.nature.com/doifinder/10.1038/387253a0

Davenport, M. and D. Anderson. 2005. “Getting From Sense of Place to Place-Based Management: An Interpretive Investigation of Place Meanings and Perceptions of Landscape Change.” Society and Natural Resources 18:625-641.

Davis, M. A. and L.B. Slobodkin. 2004. "The Science and Values of Restoration Ecology." Restoration Ecology 12(1): 1-3. 
Dean Runyan Associates. 2009. "Fishing, Hunting, Wildlife Viewing, and Shellfishing in Oregon: 2008 State and County Expenditure Estimates.” Retrieved from: http://www.dfw.state.or.us/agency/docs/Report_5_6_09--Final\%20\%282\%29.pdf on December 16, 2011.

Enders, J. 2002. “Eastern Oregon County Bans U.N., Frees Trees for Taking, Notwithstanding Applicable Federal Laws - Rebels With a Vote Vent Anger With Government.” The Associated Press. Article reprinted in The Herald Republic June 1, 2002.

Field, D.R., P.R. Voss, T.K. Kuczenski, R.B. Hammer, and V.C. Radeloff. 2003.

"Reaffirming Social Landscape Analysis in Landscape Ecology: a Conceptual Framework.” Society and Natural Resources 16: 349-361.

Flora, C.B., M. Kinsley, V. Luther, M. Wall, S. Odell, S. Ratner, and J. Topolsky. 1999. Measuring Community Success and Sustainability: An Interactive Workbook. (RRD: 180) Ames, IA: North Central Regional Center for Rural Development. Retrieved from: http://ncrcrd.msu.edu/uploads/files/133/ncrcrd-rrd180-print.pdf

Folke, C., S. Carpenter, T. Elmqvist, L. Gunderson, C.S. Holling, and B. Walker. 2002. "Resilience and Sustainable Development: Building Adaptive Capacity in a World of Transformation.” Ambio: Journal of the Human Environment 31 (5): 437-440.

Freeman, A. 1993. The Measurement of Environmental and Resource Values: Theories and Methods. Washington, D.C: Reasons for the Future.

Glaser, B. G. and A. L. Strauss. 1967. The Discovery of Grounded Theory: Strategies for Qualitative Research. Chicago, IL: Aldine Publishing Company.

Grant, K. R. 1993. “Historic Changes in River Channel and Riparian Woody Vegetation on the Middle Fork John Day Preserve.” Unpublished MS Thesis. University of Washington, Seattle, WA. 59 pages.

Guest, G., A. Bunce, and L. Johnson. 2006. "How Many Interviews Are Enough?: An ‘Experiment with Data Saturation and Variability.” Field Methods 18: 59-82.

Haque, C.E., A.K. Deb, D. Medeiros. 2009. "Integrating Conservation with Livelihood Improvement for Sustainable Development: The Experiment of an Oyster Producers' Cooperative in Southeast Brazil.” Society and Natural Resources 22(6): 554-570. 
Hibbard, M., H. Gurewitz, and T. Roark. 2009. "A Guide for Developing Socioeconomic Measures for Oregon’s Watershed Councils.” University of Oregon Institute for Policy Research and Innovation. 16 pages.

Hibbard, M. and K. Karle. 2001. "Ecosystem Restoration as Socio-Economic Development? An Assessment of the Possibilities.” Ecosystem Workforce Program.

Hibbard, M. and S. Lurie. 2009. "Socio-economic Measures for Intensively Monitored Watersheds: The Middle Fork John Day Effectiveness Monitoring Project.” University of Oregon Institute for Policy Research and Innovation. 25 pages.

Holling, C. S. 1973. "Resilience and Stability of Ecological Systems." Annual Review of Ecology \& Systematics 4: 1-23.

--- 2001. "Understanding the Complexity of Economic, Ecological, and Social Systems.” Ecosystems 4 (5): 390-405.

Hunter, L. M.; Boardman, J. D. and J. M. Saint Onge. 2005. "The Association Between Natural Amenities, Rural Population Growth, and Long-Term Residents' Economic Well-Being." Rural Sociology 70 (4): 452-469.

Jakobsen, C. H. and W. J. McLaughlin. 2004. "Communication in Ecosystem Management: A Case Study of Cross-disciplinary Integration in the Assessment Phase of the Interior Columbia Basin Ecosystem Management Project." Environmental Management 33(5): 591-605.

Kauneckis, D. and A. M. York. 2009. "An Empirical Evaluation of Private Landowner Participation in Voluntary Forest Conservation Programs.” Environmental Management 44: 468-484.

Kelly, E. C. and J. C. Bliss. 2009. "Healthy Forests, Healthy Communities: An Emerging Paradigm for Natural Resource-Dependent Communities?” Society and Natural Resources, 22 (5): 519-537.

Kershner, J.L. 1997. "Watershed Restoration: Principles and Practices.” Monitoring and Adaptive Management. 116-134.

Lauber, T. B., D. J. Decker and B. A. Knuth. 2008. "Social Networks and Communitybased Natural Resource Management.” Environmental Management 42: 677687. 
Lipton, D., K. Wellman, I.C. Sheifer, and R.F. Weifer. 1995. Economic Valuation of Natural Resources -A Handbook for Coastal Resource Policymakers. NOAA Coastal Ocean Program Decision Analysis Series 5. Silver Spring, MD: NOAA Coastal Ocean Office. Retrieved from: http://www.mdsg.umd.edu/programs/extension/valuation/PDF/00-Intro.pdf

Lovell, S. T. and W. C. Sullivan. 2006. "Environmental Benefits of Conservation Buffers in the United States: Evidence, Promise, and Open Questions." Agriculture Ecosystems \& Environment 112(4): 249-260.

Maczko, K. and L. Hidinger, eds. 2008. "Sustainable Rangelands Ecosystem Goods and Services.” Sustainable Rangelands Roundtable Monograph No. 3. Retrieved from: http://sustainable.rangelands.org/pdf/Ecosystem_Goods_Services.pdf

Maczko, K., J.A. Tanaka, R. Breckenridge, L. Hidinger, H. T. Heintz, W. E. Fox, U. P. Kreuter, C.S. Duke, J. E. Mitchell, D. W. McCollum. 2011. "Rangeland Ecosystem Goods and Services: Values and Evaluation of Opportunities for Ranchers and Land Managers." Rangelands 33(5): 30-36.

Margerum, R. D. 2008. “A Typology of Collaboration Efforts in Environmental Management.” Environmental Management 41:487-500.

Marshall C. and G. B. Rossman. 2006. Designing Qualitative Research. Los Angeles, CA: Sage Publications.

McCarthy, J. 2002, "First World Political Ecology: Lessons from the Wise Use Movement" Environment and Planning 34(7): 1281 - 1302.

Morton, L. W. and S. Padgitt. 2005. "Selecting Socio-economic Metrics for Watershed Management.” Environmental Monitoring and Assessment 103:83-98.

Moseley, C. and L. Wilson. 2002. "Community-based Monitoring for Sustainable Natural Resource Management.” Ecosystem Workforce Program, University of Oregon, Corvallis, Oregon.

National Wild and Scenic Rivers. 2011. "River Mileage Classifications for Components of the National Wild and Scenic Rivers System.” 1-22. Retrieved from: http://www.rivers.gov/publications/rivers-table.pdf

Naveh, Z. 2005. "Epilogue: Toward a Transdisciplinary Science of Ecological and Cultural Landscape Restoration.” Restoration Ecology 13(1): 228- 234. 
Nielson-Pincus, M. and C. Moseley. 2010. "The Employment and Economic Impacts of Forest and Watershed Restoration in Oregon.” Ecosystem Workforce Program, University of Oregon, Corvallis, Oregon.

Norton, B. G. and A.C. Steinemann 2001. "Environmental Values and Adaptive Management." Environmental Values 10: 473-506.

Oregon Explorer. 2011. "Oregon Watershed Restoration Report, Middle Fork John Day (17070203) Subbasin, 1995-2009.” Retrieved from: http://oe.oregonexplorer.info/RestorationTool/ on December 25, 2011.

OWEB (Oregon Watershed Enhancement Board). 2011. “2009-2011 Biennial Report.” Retrieved from: www.oregon.gov/OWEB/biennialreport2011.shtml

OWRI (Oregon Watershed Restoration Inventory). 2011. “OWRI Excel Spreadsheet.” Data managed by Bobbi Riggers, Oregon Watershed Enhancement Board. Raw data retrieved from:

http://oregonexplorer.info/EnhancingWatersheds\#TheOWRIDatabaseandGISdata on December 17, 2011.

PLAIN (Plain Language Action and Information Network). 2011. "Federal Plain Language Guidelines.” Retrieved from: http://www.plainlanguage.gov/howto/guidelines/FederalPLGuidelines/FederalPL Guidelines.pdf

Pollin, R., J. Heintz and H. Garrett-Peltier. 2009. "How Infrastructure Investments Support the U.S. Economy.” Published Studies, Political Economy Research Institute, University of Massachusetts at Amherst. Retrieved from: http://www.americanmanufacturing.org/files/peri_aam_finaljan16_new.pdf

Power, T.M. 1996 . Lost Landscapes and Failed Economies: The Search for a Value of Place. Washington, DC: Island Press.

Renting, H., W. A. H. Rossing, J.C.J. Groot, J.D. Van der Ploeg, C. Laurent, D. Perraud, D.J. Stobbelaar and M.K. Van Ittersum. 2009. "Exploring multifunctional agriculture. A review of conceptual approaches and prospects for an integrative transitional framework." Journal of Environmental Management 90(s): S112S123.

Roni, P. ed. 2005. Monitoring Stream and Watershed Restoration. Bethesda, MD: American Fisheries Society.

Smith, M. D. and R. S. Krannich. 2000. "“'Culture Clash" Revisited: Newcomer and Longer-Term Residents' Attitudes Toward Land Use, Development, and 
Environmental Issues in Rural Communities in the Rocky Mountain West." Rural Sociology 65(3): 396-421.

Spurgeon, J. 1999. "The Socio-Economic Costs and Benefits of Coastal Habitat Rehabilitation and Creation." Marine Pollution Bulletin 37(8-12): 373-382.

Strauss, A. and J. Corbin. 1998. Basics of Qualitative Research: Techniques and Procedures for Developing Grounded Theory. Thousand Oaks, CA: Sage Publications.

Thayer, G.W., D.h. Merkley, T.A. McTigue, F.M. Burrows, R.J. Salz, P.F. Gayaldo. 2003. Science-based Restoration Monitoring of Coastal Habitats. Silver Spring, MD: U.S. Department of Commerce.

United Nations General Assembly. 1987. "Report of the World Commission on Environment and Development: Our Common Future; Transmitted to the General Assembly as an Annex to document A/42/427 - Development and International Co-operation: Environment; Our Common Future, Chapter 2: Towards Sustainable Development." United Nations General Assembly. Retrieved from: http://www.un-documents.net/index.htm on 10 December 2011.

United Nations General Assembly. 2005. "2005 World Summit Outcome, Resolution A/60/1, adopted by the General Assembly on 15 September 2005.” Retrieved from: http://www.un-documents.net/index.htm on 10 December 2011.

Waage, S. A. 2001. "(Re)claiming Space and Place through Collaborative Planning in Rural Oregon." Political Geography 20(7): 839-857.

Williams, D. R. and M. E. Patterson. 1996. "Environmental Meaning and Ecosystem Management: Perspectives from Environmental Psychology and Human Geography.” Society \& Natural Resources 9(5): 507-521.

WorkSource Oregon. 2011. “Current Unemployment Rates.” Oregon Labor Market Information System. Retrieved from: http://www.qualityinfo.org/olmisj/AllRates?adjusted=y on December 26, 2011.

Wu, J., K. Skelton-Groth, W. G. Boggess, and R.M. Adams. 2003. “Pacific Salmon Restoration: Trade-offs Between Economic Efficiency and Political Acceptance.” Contemporary Economic Policy 21(1): 78-89.

Yung, L., W. A. Ereimund, and J. M. Belsky. 2003. "The Politics of Place:Understanding Meaning, Common Ground, and Political Difference on the Rocky Mountain Front.” Forest Science 49(6):855-866. 


\section{Appendix A: Interview Guide}

\section{Interview Guide- Changes in Land Use and Land Management in Grant County, Oregon \\ K. Lauren Senkyr, June 30, 2010}

- What brought you to Grant County?

o How long have you/your family lived here?

- What do you enjoy about living here?

o What about what you don’t like?

- Have you noticed any changes in the time that you've been here?

o What do you think accounts for these changes?

o How do you feel about these changes?

- How was your land used/managed in the past?

o By previous owners? By you or your family?

o Further back in history?

o (Add in prompts for specific activities we're interested in.)

- What do you do with your land now?

o Have you always done it this way?

o How did you learn about/get involved in these activities?

o Can you explain to me what led you to that decision?

o What about... (add in prompts for specific activities we're interested in.)

- What influences you when you make decisions about how to manage your land?

- What barriers or constraints have you encountered as a landowner/manager?

- As you think about what you do for a living, what's important to you about it?

- How do your practices compare to others in the County? Are they typical?

o So you mention some people do "x" or "y," from my understanding people also do "z." What do you think about that?

- What concerns you when you think about land and water issues in Grant County?

- How do you expect things will change in the future? Why?

- What would you like to see happen?

0 What should be changed?

o What should be preserved?

- Have I missed anything that that you think is particularly important?

- What else would you like to tell me about your experience as a landowner/manager in Grant County? 


\section{Appendix B. Informed Consent Form}

You are invited to participate in a research study conducted by Lauren Senkyr from Portland State University, Department of Environmental Science and Management. This research hopes to learn more about changes in land management and land use in Grant County, Oregon. You were selected as a possible participant in this study because you are a landowners/manager in Grant County who engages in practices this study is interested in learning more about.

If you decide to participate, you will be asked to participate in an interview about your experiences as a landowner or manager in Grant County, your perspectives on past, present and future land management practices, and your feelings about these matters. The interview takes 60-90 minutes to complete. They will be recorded with a digital audio recording device. You have the option of not responding to any question that you feel uncomfortable in answering. Any information that is obtained in connection with this study and that can be linked to you or identify you will be kept confidential. This information will be kept confidential by the use of a numerical identification coding scheme. Your name will only be used on the Consent forms. All other documentation will be coded with a numerical code. The only copy of the key will remain in the possession of the principal investigator. Any published or discussed data will be either be presented in a group format or will utilize the numerical code system.

Participation in the research project is voluntary. If you do decide to participate you can stop at any time without question or worry over jeopardizing your relationship with Lauren Senkyr and Portland State University. The primary purpose of this research is to increase knowledge that may help others in the future.

If you have concerns or problems about your participation in this study or your rights as a research subject, please contact the Human Subjects Research Review Committee, Office of Research and Sponsored Projects , 111 Cramer Hall, Portland State University, 503-725-8182. If you have questions about the study itself, contact Lauren Senkyr, lauren.senkyr@gmail.com, (503) 347-0848.

Your signature indicates that you have read and understand the above information and agree to take part in this study. Lauren Senkyr will make a copy of this consent form available for your personal records.

Date: Signature:

Interview \#: 


\title{
Appendix C. Human Subjects Approval
}

\section{蛋 Portland State}

\author{
Human Subjects Research Review Committee \\ Post Office Box $751 \quad 503-725-4288$ tel \\ Portland, Oregon 97207-0751 503-725-3416 fax \\ hsrrc@iists.pdx.edu
}

July 7,2010

To: K. Lauren Senkyr

From: Nancy Koroloff, HSRRC Chair

Re: HSRRC approval for your project titled, "Changes in Dry Land Use and Land Management in Grant County, Oregon" (HSRRC Proposal \# 101380)

Dear Lauren,

In accordance with your request, the Human Subjects Research Review Committee has reviewed your proposal referenced above for compliance with DHHS policies and regulations covering the protection of human subjects. The committee is satisfied that your provisions for protecting the rights and welfare of all subjects participating in the research are adequate, and your project is approved. Please not the following requirements:

Changes to Protocol: Any changes in the proposed study, whether to procedures, survey instruments, consent forms or cover letters, must be outlined and submitted to the Chair of the HSRRC immediately. The proposed changes cannot be implemented before they have been reviewed and approved by the Committee.

Continuing Review: This approval will expire on July 7,2011. It is the investigator's responsibility to ensure that a Continuing Review Report of the status of the project is submitted to the HSRRC two months before the expiration date, and that approval of the study is kept current. The Continuing Review Report is available at www.rsp.pdx.edu/compliance_human.php and in the Office of Research \& Sponsored Projects (ORSP).

Adverse Reactions: If any adverse reactions occur as a result of this study, you are required to notify the Chair of the HSRRC immediately. If the problem is serious, approval may be withdrawn pending an investigation by the Committee.

Completion of Study: Please notify the Chair of the Human Subjects Research Review Committee (campus mail code ORSP) as soon as your research has been completed. Study records, including protocols and signed consent forms for each participant, must be kept by the investigator in a secure location for three years following completion of the study.

If you have questions or concerns, please contact the HSRRC in the Office of Research and Sponsored Projects (ORSP), 503-725-4288, Unitus Building, 6th Floor, 4th \& Lincoln Streets.

cc: Joseph Maser 


\title{
Appendix D. Human Subjects Extension Approval
}

\section{蛋 Portland State}

\author{
Human Subjects Research Review Committee \\ Post Office Box 751 \\ Portland, Oregon 97207-0751 503-725-8170 fax \\ hsrrc@lists.pdx.edu
}

May 10,2011

To: Lauren Senkyr

From: Mary Oschwald, HSRRC Chair

Re: HSRRC renewal of approval for your project titled, "Changes in Land Use and Land Management in Grant County, Oregon" (HSRRC Proposal \# 101380)

As part of the Committee's continuing review, the Human Subjects Research Review Committee has reviewed your above referenced project for compliance with Department of Health and Human Services policies and regulations on the protection of human subjects.

The Committee is satisfied that your provisions for protecting the rights and welfare of all subjects participating in the research are adequate. Your project is renewed and this approval will expire on 7/7/2012. Please note the following policies:

1. If the project continues beyond the expiration date, the investigator needs to submit a Continuing Review Report form two months before the expiration date. The form is available at www.rsp.pdx.edu/compliance_human.php and in the Research \& Strategic Partnerships office.

2. To add this project's continuing review to the HSRRC/IRB meeting agenda, please refer to the HSRRC/IRB meeting schedule. Submit the report, and the required number of copies, by the submission deadline that is approximately two months before the project's expiration date. The HSRRC/IRB needs two months to do a continuing review of the project, so it is extremely important that you meet the committee's submission deadline.

3. If this project finishes before the expiration date, please contact the HSRRC administrator so that the file can be closed and records updated. It is the investigator's responsibility to keep the approval status current. If the project's approval expires while the project is active, the investigator must complete a new application and submit it for a new HSRRC review. In addition, any data collected after the expiration date cannot be used in the research. Please don't let this happen!

If you have questions or concerns, please contact the HSRRC in the Research and Strategic Partnerships (RSP) office, 503-725-4288, Market Center Building, 6th Floor, 1600 SW $4^{\text {th }}$ Ave.

cc: Joseph Maser 


\section{Appendix E. Quantification of Interview Responses}

\begin{tabular}{|l|c|c|c|c|c|}
\hline Changes & $\begin{array}{l}\text { Total \# } \\
\text { Responses }\end{array}$ & $\begin{array}{l}\text { Conservation- } \\
\text { Oriented }\end{array}$ & $\begin{array}{l}\text { Production } \\
\text { Agriculture }\end{array}$ & $\begin{array}{l}\text { Middle } \\
\text { Fork }\end{array}$ & $\begin{array}{l}\text { Grant } \\
\text { County }\end{array}$ \\
\hline Improved ecological conditions & $\mathbf{6}$ & $\mathbf{5}$ & $\mathbf{1}$ & $\mathbf{3}$ & $\mathbf{3}$ \\
\hline $\begin{array}{l}\text { Decline of timber industry/job } \\
\text { loss }\end{array}$ & $\mathbf{6}$ & $\mathbf{0}$ & $\mathbf{6}$ & $\mathbf{3}$ & $\mathbf{3}$ \\
\hline Community degradation & $\mathbf{5}$ & $\mathbf{0}$ & $\mathbf{5}$ & $\mathbf{1}$ & $\mathbf{4}$ \\
\hline Resource management changes & $\mathbf{5}$ & $\mathbf{2}$ & $\mathbf{3}$ & $\mathbf{4}$ & $\mathbf{1}$ \\
\hline Fewer working ranches & $\mathbf{4}$ & $\mathbf{0}$ & $\mathbf{4}$ & $\mathbf{1}$ & $\mathbf{3}$ \\
\hline $\begin{array}{l}\text { Increased environmental } \\
\text { awareness }\end{array}$ & $\mathbf{4}$ & $\mathbf{2}$ & $\mathbf{2}$ & $\mathbf{2}$ & $\mathbf{2}$ \\
\hline $\begin{array}{l}\text { Shift in public perception of } \\
\text { ranchers }\end{array}$ & $\mathbf{4}$ & $\mathbf{0}$ & $\mathbf{4}$ & $\mathbf{0}$ & $\mathbf{4}$ \\
\hline $\begin{array}{l}\text { Acknowledgement of economic } \\
\text { contributions of restoration }\end{array}$ & $\mathbf{3}$ & $\mathbf{3}$ & $\mathbf{0}$ & $\mathbf{3}$ & $\mathbf{0}$ \\
\hline $\begin{array}{l}\text { Economics of cattle industry are } \\
\text { more difficult }\end{array}$ & $\mathbf{3}$ & $\mathbf{0}$ & $\mathbf{3}$ & $\mathbf{1}$ & $\mathbf{2}$ \\
\hline Turnover at USFS & $\mathbf{2}$ & $\mathbf{1}$ & $\mathbf{1}$ & $\mathbf{1}$ & $\mathbf{1}$ \\
\hline & & & & & \\
\hline Attitude Towards Change & & $\mathbf{2}$ & & & \\
\hline Positive & $\mathbf{2}$ & $\mathbf{1}$ & $\mathbf{1}$ & $\mathbf{1}$ & $\mathbf{1}$ \\
\hline Have to adapt & $\mathbf{4}$ & $\mathbf{0}$ & $\mathbf{4}$ & $\mathbf{2}$ & $\mathbf{2}$ \\
\hline Negative & & & & & \\
\hline & $\mathbf{6}$ & $\mathbf{1}$ & $\mathbf{5}$ & $\mathbf{3}$ & $\mathbf{3}$ \\
\hline Causes of Change & $\mathbf{3}$ & $\mathbf{1}$ & $\mathbf{2}$ & $\mathbf{2}$ & $\mathbf{1}$ \\
\hline Economic drivers & $\mathbf{2}$ & $\mathbf{0}$ & $\mathbf{2}$ & $\mathbf{1}$ & $\mathbf{1}$ \\
\hline Natural evolution & & & & \\
\hline Politics & & & & & \\
\hline Regulation & & & & & \\
\hline
\end{tabular}

Table A. Responses to the questions: "Have you noticed any changes in the time that you've been here? How do you feel about these changes? What do you think accounts for these changes?" and changes mentioned at other points in the interviews.

\begin{tabular}{|l|c|c|c|c|c|}
\hline Concerns & $\begin{array}{l}\text { Total \# } \\
\text { Responses }\end{array}$ & $\begin{array}{l}\text { Conservation- } \\
\text { Oriented }\end{array}$ & $\begin{array}{l}\text { Production } \\
\text { Agriculture }\end{array}$ & $\begin{array}{l}\text { Middle } \\
\text { Fork }\end{array}$ & $\begin{array}{l}\text { Grant } \\
\text { County }\end{array}$ \\
\hline Water rights/ water quantity & $\mathbf{5}$ & $\mathbf{2}$ & $\mathbf{3}$ & $\mathbf{3}$ & $\mathbf{2}$ \\
\hline Extremism & $\mathbf{5}$ & $\mathbf{1}$ & $\mathbf{4}$ & $\mathbf{2}$ & $\mathbf{3}$ \\
\hline $\begin{array}{l}\text { Implementation of } \\
\text { policy/regulation }\end{array}$ & $\mathbf{4}$ & $\mathbf{1}$ & $\mathbf{3}$ & $\mathbf{2}$ & $\mathbf{2}$ \\
\hline $\begin{array}{l}\text { Long term } \\
\text { maintenance/consistency }\end{array}$ & $\mathbf{3}$ & $\mathbf{1}$ & $\mathbf{2}$ & $\mathbf{2}$ & $\mathbf{1}$ \\
\hline $\begin{array}{l}\text { Increased pressure on private } \\
\text { lands }\end{array}$ & $\mathbf{3}$ & $\mathbf{0}$ & $\mathbf{3}$ & $\mathbf{1}$ & $\mathbf{2}$ \\
\hline Preservation mentality & $\mathbf{2}$ & $\mathbf{0}$ & $\mathbf{2}$ & $\mathbf{1}$ & $\mathbf{1}$ \\
\hline Breaking up large tracts of land & $\mathbf{2}$ & $\mathbf{1}$ & $\mathbf{1}$ & $\mathbf{2}$ & $\mathbf{0}$ \\
\hline
\end{tabular}

Table B. Responses to the question: What concerns you when you think about land and water issues in Grant County? And other concerns mentioned during the interviews. 


\begin{tabular}{|c|c|c|c|c|c|}
\hline $\begin{array}{l}\text { Past Land Management } \\
\text { Practices }\end{array}$ & $\begin{array}{l}\text { Total \# } \\
\text { Responses }\end{array}$ & $\begin{array}{l}\text { Conservation- } \\
\text { Oriented }\end{array}$ & $\begin{array}{l}\text { Production } \\
\text { Agriculture }\end{array}$ & $\begin{array}{l}\text { Middle } \\
\text { Fork }\end{array}$ & $\begin{array}{l}\text { Grant } \\
\text { County }\end{array}$ \\
\hline Grazing & 13 & $\mathbf{n} / \mathbf{a}$ & $\mathbf{n} / \mathbf{a}$ & 8 & 5 \\
\hline Overgrazing & 5 & $\mathbf{n} / \mathbf{a}$ & $\mathbf{n} / \mathbf{a}$ & 4 & 1 \\
\hline Season long grazing & 4 & $\mathbf{n} / \mathbf{a}$ & $\mathbf{n} / \mathbf{a}$ & 2 & 1 \\
\hline No fencing & 2 & $\mathbf{n} / \mathbf{a}$ & $\mathbf{n} / \mathbf{a}$ & $\mathbf{0}$ & 2 \\
\hline Used federal allotments & 2 & $\mathbf{n} / \mathbf{a}$ & $\mathbf{n} / \mathbf{a}$ & 1 & 1 \\
\hline Logging & 9 & $\mathbf{n} / \mathbf{a}$ & $\mathbf{n} / \mathbf{a}$ & 8 & 1 \\
\hline Irrigated hay fields & 6 & $\mathbf{n} / \mathbf{a}$ & $\mathbf{n} / \mathbf{a}$ & 6 & $\mathbf{0}$ \\
\hline Mining & 4 & $\mathbf{n} / \mathbf{a}$ & $\mathbf{n} / \mathbf{a}$ & 4 & $\mathbf{0}$ \\
\hline Realigned creek to increase hay & 2 & $\mathbf{n} / \mathbf{a}$ & $\mathbf{n} / \mathbf{a}$ & 2 & $\mathbf{0}$ \\
\hline $\begin{array}{l}\text { Subsistence animals (cows, } \\
\text { chickens) }\end{array}$ & 2 & $\mathbf{n} / \mathbf{a}$ & $\mathbf{n} / \mathbf{a}$ & 2 & $\mathbf{0}$ \\
\hline \multicolumn{6}{|l|}{$\begin{array}{l}\text { Current Land Management } \\
\text { Practices }\end{array}$} \\
\hline \multicolumn{6}{|l|}{ Grazing } \\
\hline Fencing & 6 & 2 & 4 & 4 & 2 \\
\hline Lease land & 5 & 1 & 5 & 2 & 3 \\
\hline Rest rotations & 4 & $\mathbf{0}$ & 4 & 1 & 3 \\
\hline Use federal allotments & 4 & 1 & 3 & 2 & 2 \\
\hline "Demonstration grazing" & 3 & 2 & 1 & 2 & 1 \\
\hline \multicolumn{6}{|l|}{ Irrigation } \\
\hline Actively irrigate & 11 & 4 & 7 & 7 & 4 \\
\hline Lease water rights instream & 5 & 4 & 1 & 5 & $\mathbf{0}$ \\
\hline Irrigation efficiency projects & 4 & 1 & 3 & 2 & 2 \\
\hline Diversion with fish screen & 2 & $\mathbf{0}$ & 2 & $\mathbf{0}$ & 2 \\
\hline Conservation easements & 4 & 3 & 1 & 4 & $\mathbf{0}$ \\
\hline Instream restoration & 9 & 5 & 4 & 6 & 3 \\
\hline Riparian planting & 7 & 5 & 2 & 6 & 1 \\
\hline \multicolumn{6}{|l|}{ Mining } \\
\hline Instream & 1 & 1 & $\mathbf{0}$ & 1 & $\mathbf{0}$ \\
\hline Gravel pit & 2 & 1 & 1 & 2 & $\mathbf{0}$ \\
\hline \multicolumn{6}{|l|}{ Forest management } \\
\hline Logging & 4 & 1 & 3 & 3 & 1 \\
\hline Thinning & 4 & 3 & 1 & 3 & 1 \\
\hline Prescribed burn & 4 & 2 & 2 & 2 & 2 \\
\hline Juniper removal & 6 & 1 & 5 & 3 & 3 \\
\hline Weed management & 10 & 5 & 5 & 6 & 4 \\
\hline
\end{tabular}

Table C. Responses to the questions: "How was your land used/managed in the past? What do you do with your land now?" and land management practices mentioned at other points in the interviews. 


\begin{tabular}{|l|c|c|c|c|c|}
\hline Decision Making & $\begin{array}{l}\text { Total \# } \\
\text { Responses }\end{array}$ & $\begin{array}{l}\text { Conservation- } \\
\text { Oriented }\end{array}$ & $\begin{array}{l}\text { Production } \\
\text { Agriculture }\end{array}$ & $\begin{array}{l}\text { Middle } \\
\text { Fork }\end{array}$ & $\begin{array}{l}\text { Grant } \\
\text { County }\end{array}$ \\
\hline Finances & $\mathbf{7}$ & $\mathbf{1}$ & $\mathbf{6}$ & $\mathbf{3}$ & $\mathbf{4}$ \\
\hline Ecological benefit & $\mathbf{5}$ & $\mathbf{3}$ & $\mathbf{2}$ & $\mathbf{3}$ & $\mathbf{2}$ \\
\hline Management plan & $\mathbf{5}$ & $\mathbf{5}$ & $\mathbf{0}$ & $\mathbf{5}$ & $\mathbf{0}$ \\
\hline Mutual benefit & $\mathbf{2}$ & $\mathbf{0}$ & $\mathbf{2}$ & $\mathbf{1}$ & $\mathbf{1}$ \\
\hline Improve the land & $\mathbf{3}$ & $\mathbf{0}$ & $\mathbf{3}$ & $\mathbf{0}$ & $\mathbf{3}$ \\
\hline Common sense & $\mathbf{2}$ & $\mathbf{0}$ & $\mathbf{2}$ & $\mathbf{1}$ & $\mathbf{1}$ \\
\hline People who introduce the idea & $\mathbf{2}$ & $\mathbf{0}$ & $\mathbf{2}$ & $\mathbf{1}$ & $\mathbf{1}$ \\
\hline Public pressure & $\mathbf{2}$ & $\mathbf{1}$ & $\mathbf{1}$ & $\mathbf{1}$ & $\mathbf{1}$ \\
\hline Sustainability & $\mathbf{2}$ & $\mathbf{0}$ & $\mathbf{2}$ & $\mathbf{1}$ & $\mathbf{1}$ \\
\hline
\end{tabular}

Table D. Responses to the questions: "What do you do with your land now? Have you always done it this way? How did you learn about/get involved in these activities? Can you explain to me what led you to that decision?" and "What influences you when you make decisions about how to manage your land?"

\begin{tabular}{|l|c|c|c|c|c|}
\hline Barriers and Constraints & $\begin{array}{l}\text { Total \# } \\
\text { Responses }\end{array}$ & $\begin{array}{l}\text { Conservation- } \\
\text { Oriented }\end{array}$ & $\begin{array}{l}\text { Production } \\
\text { Agriculture }\end{array}$ & $\begin{array}{l}\text { Middle } \\
\text { Fork }\end{array}$ & $\begin{array}{l}\text { Grant } \\
\text { County }\end{array}$ \\
\hline Regulation & $\mathbf{9}$ & $\mathbf{3}$ & $\mathbf{6}$ & $\mathbf{4}$ & $\mathbf{5}$ \\
\hline Finances & $\mathbf{4}$ & $\mathbf{0}$ & $\mathbf{4}$ & $\mathbf{2}$ & $\mathbf{2}$ \\
\hline Resistance/skepticism & $\mathbf{3}$ & $\mathbf{2}$ & $\mathbf{1}$ & $\mathbf{3}$ & $\mathbf{0}$ \\
\hline Taxation & $\mathbf{2}$ & $\mathbf{0}$ & $\mathbf{2}$ & $\mathbf{0}$ & $\mathbf{2}$ \\
\hline Litigation & $\mathbf{2}$ & $\mathbf{1}$ & $\mathbf{1}$ & $\mathbf{1}$ & $\mathbf{1}$ \\
\hline Upstream management & $\mathbf{2}$ & $\mathbf{2}$ & $\mathbf{0}$ & $\mathbf{2}$ & $\mathbf{0}$ \\
\hline
\end{tabular}

Table E. Responses to the question: "What barriers or constraints have you encountered as a landowner or land manager?”

\begin{tabular}{|l|c|c|c|c|c|}
\hline Hopes for the Future & $\begin{array}{l}\text { Total \# } \\
\text { Responses }\end{array}$ & $\begin{array}{l}\text { Conservation- } \\
\text { Oriented }\end{array}$ & $\begin{array}{l}\text { Production } \\
\text { Agriculture }\end{array}$ & $\begin{array}{l}\text { Middle } \\
\text { Fork }\end{array}$ & $\begin{array}{l}\text { Grant } \\
\text { County }\end{array}$ \\
\hline $\begin{array}{l}\text { Agreement between } \\
\text { landowners and agencies } \\
\text { about shared priorities/values }\end{array}$ & $\mathbf{5}$ & $\mathbf{2}$ & $\mathbf{3}$ & $\mathbf{2}$ & $\mathbf{3}$ \\
\hline Increased timber harvest & $\mathbf{3}$ & $\mathbf{1}$ & $\mathbf{2}$ & $\mathbf{1}$ & $\mathbf{2}$ \\
\hline Sustainability & $\mathbf{2}$ & $\mathbf{1}$ & $\mathbf{1}$ & $\mathbf{1}$ & $\mathbf{1}$ \\
\hline $\begin{array}{l}\text { Positive public perception of } \\
\text { ranchers }\end{array}$ & $\mathbf{2}$ & $\mathbf{0}$ & $\mathbf{2}$ & $\mathbf{1}$ & $\mathbf{1}$ \\
\hline More restoration & $\mathbf{2}$ & $\mathbf{1}$ & $\mathbf{1}$ & $\mathbf{1}$ & $\mathbf{1}$ \\
\hline Economic resurgence & $\mathbf{2}$ & $\mathbf{1}$ & $\mathbf{1}$ & $\mathbf{2}$ & $\mathbf{0}$ \\
\hline Price of beef increases & $\mathbf{2}$ & $\mathbf{0}$ & $\mathbf{2}$ & $\mathbf{0}$ & $\mathbf{2}$ \\
\hline $\begin{array}{l}\text { Local management of } \\
\text { resources }\end{array}$ & $\mathbf{2}$ & $\mathbf{0}$ & $\mathbf{2}$ & $\mathbf{0}$ & $\mathbf{2}$ \\
\hline
\end{tabular}

Table F. Responses to the question: "How do you expect things will change in the future? Why? What would you like to see happen? What should be changed? What should be preserved?” and other hopes or expectations for the future that were mentioned at other points in the interviews. 